\title{
Synthesis of Heterosubstituted Hexaaryl- benzenes via Asymmetric Carbonylative Couplings of Benzyl Halides
}

\author{
Robert G. Potter, Thomas S. Hughes \\ Department of Chemistry, Cook Physical Sciences Building, 82 University Place, University of Vermont, \\ Burlington, VT 05401
}

Table of Contents

Synthesis of Compounds 7

Synthesis of Compounds 6

Supporting Information

Synthesis of Collman's Reagent

Kinetics of formation of $\mathbf{1}$

Synthesis of Compounds 1

Synthesis of Compounds 2

Synthesis of Compounds 4

\begin{tabular}{l}
\hline 1 \\
3 \\
4 \\
5 \\
6 \\
10 \\
13 \\
16 \\
\hline 24 \\
32 \\
54 \\
66 \\
\hline
\end{tabular}

${ }^{1} \mathrm{H}$ and ${ }^{13} \mathrm{C}$ NMR of Compounds 7

${ }^{1} \mathrm{H}$ and ${ }^{13} \mathrm{C}$ NMR of Compounds 6

${ }^{1} \mathrm{H}$ and ${ }^{13} \mathrm{C}$ NMR of Compounds $\mathbf{1}$

${ }^{1} \mathrm{H}$ and ${ }^{13} \mathrm{C}$ NMR of Compounds 2

${ }^{1} \mathrm{H}$ and ${ }^{13} \mathrm{C}$ NMR of Compounds 4

\section{$\underline{\text { Experimental Details }}$}

General Details NMR spectra were recorded on a Varian $500 \mathrm{MHz}$ or Bruker ARX-500 instrument (at 500 and $125 \mathrm{MHz}$ for ${ }^{1} \mathrm{H}$ and ${ }^{13} \mathrm{C}$ respectively) at room temperature $(303 \mathrm{~K}+/-1 \mathrm{~K})$ in chloroform unless otherwise indicated. IR spectra were recorded on a Thermo Nicolet IR200, and were obtained neat at room temperature unless otherwise indicated; IR spectra of solids were obtained using an ATF probe. Low resolution CI-MS were recorded on a HP 5988 GCMS using a 5\% phenyl column. All starting materials were obtained from Aldrich, Acros or Strem and were used without further purification. NMP was dried by distilling the benzene-water azeotrope from an NMP-benzene mixture. THF was purified by distillation from sodium-benzophenone ketyl under nitrogen. $\mathrm{CH}_{2} \mathrm{Cl}_{2}$ was purified by distillation from calcium hydride under nitrogen.

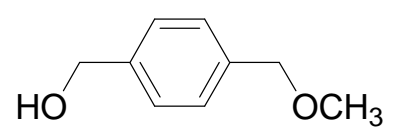


(4-Methoxymethylphenyl)methanol ${ }^{\mathbf{1}}$ (7a) $3.13 \mathrm{~g}$ of $p$-benzenedimethanol $(22.7 \mathrm{mmol})$ in 150 $\mathrm{ml}$ THF was treated with 0.9 equivalents of sodium hydride. The reaction mixture was stirred for 30 minutes prior to injection of $1.4 \mathrm{ml}(22.4 \mathrm{mmol})$ iodomethane, added over 5 minutes. The reaction was then stirred overnight, diluted with ether and quenched over water. The organic layer was retained and the aqueous layer extracted 3 times with ether. The combined organic layers were dried over calcium sulfate and concentrated in vacuo. Flash chromatography $(10 \%$ ethyl acetate in hexanes) was then performed to afford the pure monoprotected alcohol in $70.2 \%$ yield with respect to recovered starting material. ( $0.959 \mathrm{~g}, 70 \%$ ); ${ }^{1} \mathrm{H}$ NMR $d 7.29$ (s, 4H), 4.59 (s, 2H), 4.42 (s, 2H), 3.35 (s, 3H), 2.77 (br. s, 1H); ${ }^{13} \mathrm{C}$ NMR $d$ 140.45, 137.16, 127.76, 126.84, 74.30, 64.61, 57.82; IR (neat, $\mathrm{cm}^{-1}$ ): 3336.45, 2900.68, 1516.8, 1411.29, 1341.77, 1307.63, $1199.83,1093.38,1015.28,962.60,914.76,820.35,670.57$.

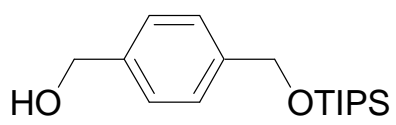

(4-Triisopropylsiloxylmethylphenyl)methanol ${ }^{2}$ (7b) $2.78 \mathrm{~g}$ of $p$-benzenedimethanol $(20.1$ mmol) was stirred with $1.565 \mathrm{~g}$ of imidazole $(22.9 \mathrm{mmol})$ in $150 \mathrm{ml}$ THF for 15 minutes prior to introduction of $1.3 \mathrm{ml}$ of chlorotriisopropylsilane $(6.1 \mathrm{mmol})$. The reaction was stirred at room temperature for 24 hours, diluted in $200 \mathrm{ml}$ ether and $150 \mathrm{ml}$ brine. Column chromatography (silica gel/10\% ethyl acetate in hexanes) gave the monoprotected alcohol as a colorless, viscous oil in $90 \%$ yield with respect to recovered starting material. (1.70g, 90\%); ${ }^{1} \mathrm{H}$ NMR $d 7.36(\mathrm{~d}, J$ $=8.0 \mathrm{~Hz}, 2 \mathrm{H}), 7.32(\mathrm{~d}, J=8.0 \mathrm{~Hz}, 2 \mathrm{H}), 4.82(\mathrm{~s}, 2 \mathrm{H}), 4.69(\mathrm{~s}, 2 \mathrm{H}), 2.05(\mathrm{~s}, 1 \mathrm{H}), 1.16(\mathrm{~m}, 3 \mathrm{H}), 1.1$ (m, 21H); ${ }^{13}$ C NMR $d 141.12,139.31,126.92,125.89,65.16,64.78,18.01,11.98$; IR (neat, $\mathrm{cm}^{-}$ $\left.{ }^{1}\right), 3350.93,2929.25,2857.29,1471.98,1255.94,1091.14,838.03,777.18$

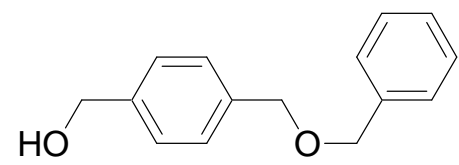

(4-Phenylmethoxymethylphenyl)methanol $\quad(7 \mathbf{c}) \quad 0.886$ grams $\quad\left(\begin{array}{lllll}6.4 & \mathrm{mmol}\end{array}\right)$ of $\quad 1,4$ benzenedimethanol was dissolved in $150 \mathrm{ml}$ THF and stirred in an ice bath for 20 minutes prior to introduction of $0.20 \mathrm{~g}$ sodium hydride $(5.0 \mathrm{mmol})$. The flask was then removed from the ice bath and stirred at room temperature for 45 minutes prior to injection of $1.5 \mathrm{ml}$ of benzyl bromide $(12.54 \mathrm{mmol})$. The reaction mixture was then immediately heated to reflux and stirred for 8 hours before cooling to room temperature and was then stirred overnight. The crude reaction mixture was poured over $100 \mathrm{ml}$ saturated aqueous ammonium chloride and extracted with three $100 \mathrm{ml}$ portions of ether. Column chromatography (10\% ethyl acetate in hexanes) gave the desired product $\left(0.553 \mathrm{~g}, 66.1 \%\right.$ yield with respect to recovered diol). ${ }^{1} \mathrm{H}$ NMR $d 7.41$ $7.29(\mathrm{~m}, 9 \mathrm{H}), 4.66(\mathrm{~s}, 2 \mathrm{H}), 4.57(\mathrm{~s}, 4 \mathrm{H}) ;{ }^{13} \mathrm{C}$ NMR $d 140.32,138.13,137.57,128.36,127.95$, $127.74,127.61,127.00,72.01,71.76,64.96 ; \quad I R$ (neat, $\mathrm{cm}^{-1}$ ) 3371.26, 3032.70, 2895.23, 2862.07, 1419.82, 1361.06, 1215.74, 1067.15, 1009.90, 902.93, 837.46, 744.91, 693.83, CIGCMS: Calc. for $\mathrm{C}_{15} \mathrm{H}_{16} \mathrm{O}_{2}\left({ }^{+} \mathrm{M}+\mathrm{H}\right): 229.12$, Found: 229.2 


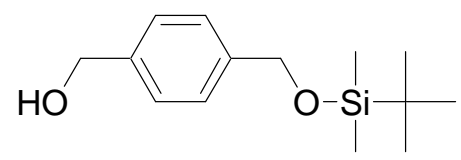

(4-tert-Butyldimethylsiloxylmethylphenyl)methanol ${ }^{\mathbf{3}}$ (7d) $5.263 \mathrm{~g}$ (38.09 mmol) of 1,4 benzenedimethanol and $1.016 \mathrm{~g}$ of imidazole $(14.93 \mathrm{mmol})$ was dissolved in $250 \mathrm{ml} \mathrm{THF}$ and stirred in ice bath prior to addition of $2.272 \mathrm{~g}(15.07 \mathrm{mmol})$ of chloro-tert-butyldimethylsilane. The flask was then removed from the ice bath and stirred for 12 hours. The reaction was then poured over $150 \mathrm{ml}$ of brine and extracted with three $100 \mathrm{ml}$ portions of 4:1 hexanes:ether. The combined organic layers were dried with a minimal amount of calcium chloride, and the solvent was removed under reduced pressure. Column chromatography gives the monoprotected alcohol. (2.88 g, 84.5\% with respect to the silyl chloride); ${ }^{1} \mathrm{H}$ NMR $d 7.32(\mathrm{~s}, 4 \mathrm{H}), 4.75$ (s, 2H), $4.68(\mathrm{~s}, 2 \mathrm{H}), 0.98(\mathrm{~s}, 9 \mathrm{H}), 0.13(\mathrm{~s}, 6 \mathrm{H}) ;{ }^{13} \mathrm{C}$ NMR $d 140.70,139.57,126.87,126.18,64.89,64.76$, 25.90, 18.34, -5.30; IR (neat, $\mathrm{cm}^{-1}$ ): 3344.08, 2929.13, 2925.53, 2884.35, 2857.27, 1471.97, 1255.90, 1213.64, 1091.47, 838.42, 777.09

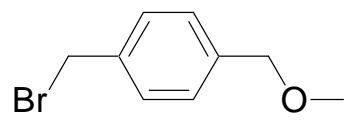

1-Bromomethyl-4-methoxymethylbenzene (6a) $1.189 \mathrm{~g}$ of $N$-bromosuccinimide (6.68 mmol) was dissolved in $70 \mathrm{ml} \mathrm{CH} \mathrm{Cl}_{2}$ and stirred at $0{ }^{\circ} \mathrm{C}$ for 5 minutes prior to injection of $0.9 \mathrm{ml}$ of methyl sulfide $(12.17 \mathrm{mmol})$ over several minutes. The reaction mixture was stirred at this temperature for 10 minutes, then cooled to $-20{ }^{\circ} \mathrm{C}$ and stirred for 10 minutes. A solution of $0.918 \mathrm{~g}$ of alcohol $7 \mathbf{a}(6.0 \mathrm{mmol})$ in $20 \mathrm{ml} \mathrm{CH}_{2} \mathrm{Cl}_{2}$ was cooled to $-20{ }^{\circ} \mathrm{C}$, added and the resultant mixture stirred for 15 minutes. The reaction mixture was then warmed to $0{ }^{\circ} \mathrm{C}$ and stirred for another 15 minutes, before warning to room temperature and stirring for 12 hours. The reaction mixture was then poured over $6 \mathrm{ml}$ of brine and extracted with three portions of 4:1 hexanes:ether. The combined organic portions were dried over calcium chloride. The solvent was removed under reduced pressure, and column chromatography $(10 \%$ ethyl acetate in hexanes) gave the pure bromide. $(1.27 \mathrm{~g}, 92.4 \%) ;{ }^{1} \mathrm{H}$ NMR $d 7.38(\mathrm{~d}, J=8.2 \mathrm{~Hz}, 2 \mathrm{H}), 7.31 \quad(\mathrm{~d}, J$ $=8.2 \mathrm{~Hz}, 2 \mathrm{H}), 4.50(\mathrm{~s}, 2 \mathrm{H}), 4.45(\mathrm{~s}, 2 \mathrm{H}), 3.39(\mathrm{~s}, 3 \mathrm{H}) ;{ }^{13} \mathrm{C}$ NMR $d$ 138.54, 137.08, 129.06, 127.08, 74.15, 58.15, 33.29; IR (neat, $\mathrm{cm}^{-1}$ ) 2925.16, 2821.39, 1380.78, 1228.28, 1201.55, 1194.88, 1096.78, 820.56, 606.72; CI-MS: Calc. for $\mathrm{C}_{9} \mathrm{H}_{11} \mathrm{OBr}$ : 214.00, Found: 184.6 (20, M$\left.\mathrm{OCH}_{3}\right), 182.8$ (20, M-OCH$), 135.0$ (100, M-Br).

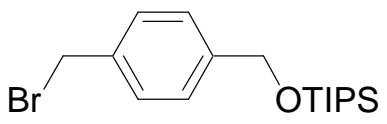

(4-Bromomethylbenzyloxy)triisopropylsilane (6b) The procedure used was the same as that for $6 \mathbf{a}$, using $2.02 \mathrm{~g}$ of NBS, $1.0 \mathrm{ml}$ of $\mathrm{Me}_{2} \mathrm{~S}$ and $2.29 \mathrm{~g}$ of $7 \mathbf{b}$. Florisil was employed as the stationary phase for the flash column, and was required to prevent decomposition of the silyl ether, which was observed with silica. $(2.35 \mathrm{~g}, 84.5 \%) ;{ }^{1} \mathrm{H} \mathrm{NMR} d 7.36(\mathrm{~d}, J=8.4 \mathrm{~Hz}, 2 \mathrm{H})$, $7.33(\mathrm{~d}, J=8.4 \mathrm{~Hz}, 2 \mathrm{H}), 4.83(\mathrm{~s}, 2 \mathrm{H}), 4.50$ (s, 2H), $1.22-1.14(\mathrm{~m}, 3 \mathrm{H}), 1.10$ (d, $J=6.7 \mathrm{~Hz}$, 
$18 \mathrm{H}) ;{ }^{13} \mathrm{C}$ NMR $d 142.1,136.2,128.9,126.1,64.7,33.5,18.0,12.1$; IR (neat, $\mathrm{cm}^{-1}$ ): 2943.45 , 2866.30, 1515.78, 1463.27, 1373.16, 1260.40, 1212.57, 1094.32, 1014.50, 882.47, 806.23, 682.04; CI-GCMS: Calc. for $\mathrm{C}_{17} \mathrm{H}_{30} \mathrm{BrOSi}\left({ }^{+} \mathrm{M}+\mathrm{H}\right)$ : 357.1249, Found: 357.4 .

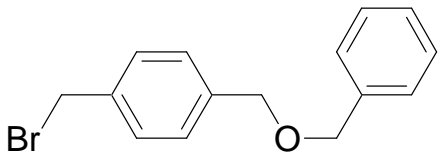

1-Bromomethyl-4-phenylmethoxymethylbenzene $(6 \mathbf{c})$ The procedure used was the same as that for 6a, using $0.42 \mathrm{~g}(2.36 \mathrm{mmol})$ of NBS, $0.20 \mathrm{ml}(2.7 \mathrm{mmol})$ of $\mathrm{Me}_{2} \mathrm{~S}$ and $0.447 \mathrm{~g}(1.96$ mmol) of 7c. $(0.47 \mathrm{~g}, 82 . \%)$; ${ }^{1} \mathrm{H}$ NMR $d 7.40-7.33(\mathrm{~m}, 8 \mathrm{H}), 7.32-7.28(\mathrm{~m}, 1 \mathrm{H}), 4.57(\mathrm{~s}, 2 \mathrm{H})$, $4.56(\mathrm{~s}, 2 \mathrm{H}), 4.50(\mathrm{~s}, 2 \mathrm{H}) ;{ }^{13} \mathrm{C} \mathrm{NMR} d 138.62,138.04,137.02,129.04,128.35,127.97,127.67$, 127.68, 72.16, 71.53, 33.28; IR (neat, $\mathrm{cm}^{-1}$ ): 2846.64, 1420.98, 1360.22, 1198.80, 1066.79, 904.25, 837.60, 751.08, 697.73; CI-GCMS: Calc. for $\mathrm{C}_{15} \mathrm{H}_{16} \mathrm{BrOSi}\left({ }^{+} \mathrm{M}+\mathrm{H}\right)$ : 291.0385, Found: 291.2.

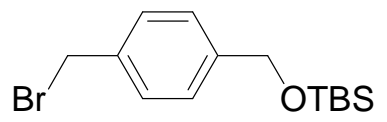

(4-Bromomethylbenzyloxy)-tert-butyldimethylsilane ${ }^{4}(\mathbf{6 d})$ The procedure used was the same as that for 7a, using $2.57 \mathrm{~g}(14.44 \mathrm{mmol})$ of NBS in $180 \mathrm{ml}$ dichloromethane, $1.4 \mathrm{ml}(18.9$ $\mathrm{mmol})$ of $\mathrm{Me}_{2} \mathrm{~S}$ and $2.25 \mathrm{~g}(8.91 \mathrm{mmol})$ of $\mathbf{5 d}$ in $50 \mathrm{ml}$ dichloromethane. Florisil was employed as the stationary phase for the flash column, and was required to prevent decomposition of the silyl ether, which was observed with silica. A higher yield has been reported using a similar procedure. ${ }^{4}(1.93 \mathrm{~g}, 61 \%) ;{ }^{1} \mathrm{H}$ NMR $d 7.37(\mathrm{~d}, J=8.2 \mathrm{~Hz}, 2 \mathrm{H}), 7.31(\mathrm{~d}, J=8.0 \mathrm{~Hz}, 2 \mathrm{H}), 4.74$ $(\mathrm{s}, 2 \mathrm{H}), 4.51(\mathrm{~s}, 2 \mathrm{H}), 0.96(\mathrm{~s}, 9 \mathrm{H}), 0.12(\mathrm{~s}, 6 \mathrm{H}) ;{ }^{13} \mathrm{C}$ NMR $d$ 141.87, 136.32, 128.93, 126.35, $64.56,33.53,25.92,18.39,-5.30$.

$$
\mathrm{Fe}(\mathrm{CO})_{5}+\mathrm{Na} \longrightarrow \mathrm{Na}_{2} \mathrm{Fe}(\mathrm{CO})_{4}{ }^{*} \mathrm{xTHF}
$$

Disodium Tetracarbonylferrate ${ }^{5}$ Collman reagent was prepared using the standard literature (REFERENCE) procedure. Dioxane was distilled over sodium, deoxygenated, and transferred to a deoxygenated flask with a stoichiometric amount of sodium and a catalytic amount of benzophenone and brought to reflux. After an hour of refluxing and deoxygenation iron pentacarbonyl (deoxygenated and prefiltered though glass wool under nitrogen) was introduced dropwise. This addition can occur rapidly, at first, while still maintaining the color of the dark blue ketyl. In later stages of the reaction the reaction of the ketyl/iron pentacarbonyl slows with decrease in concentration of the sodium/ketyl and addition must be decreased to as low as one drop per hour to ensure complete equilibrium conversion. The reduction of $\mathrm{Fe}(\mathrm{CO})_{5}$ concentration prevents the following equilibrium from being significant:

$$
\mathrm{Fe}(\mathrm{CO})_{4}{ }^{2-}+\mathrm{Fe}(\mathrm{CO})_{5} \longrightarrow \mathrm{Fe}_{2}(\mathrm{CO})_{8}^{-}
$$


Once the dark color of ketyl was suppressed (after several hours of reflux without return of ketyl) the reaction was cooled to room temperature at which time the crystals were washed with several portions of 1:1 THF: hexanes, placed under high vacuum overnight and stored under inert atmosphere.

Kinetic Measurements IR spectra were recorded using a Remspec in situ FTIR spectrometer with an ATR probe. To $2.42 \mathrm{ml}$ of a $0.436 \mathrm{M}$ solution of iron tetracarbonyl disodium in NMP was added a solution of $29.5 \mathrm{ml}$ of a $0.0949 \mathrm{M}$ solution of a 4-methylbenzylbromide in NMP. Spectra were recorded every 37 seconds until no change in the spectra was observed. The disappearance of Collman reagent with characteristic frequencies of $1876 \mathrm{~cm}^{-1}$ and $1907 \mathrm{~cm}^{-1}$ was observed with a concurrent appearance of a new reaction component at a frequency of 1916 $\mathrm{cm}^{-1}$. The concentration of the new component evolved with time in a manner consistent with a mixed-second order reaction, and the data was fit to the appropriate mathematical function, ${ }^{6}$ shown below, using nonlinear least squares fitting:

$$
-\frac{d[A]}{d t}=\frac{[B][A]\left(1-e^{([A]-[B]) k t}\right)}{[B]-[A] e^{([A]-[B]) k t}}
$$

where [A] represents the concentration of iron tetracarbonyl disodium and [B] represents the concentration of benzyl bromide. The rate expression for the production of the intermediate $\mathbf{5}$ follows the same form.

The appearance of 5 was followed at $1924 \mathrm{~cm}^{-1}$, and the experimental data (diamonds) is shown with the fitted curve (solid line). The $\mathrm{x}$ axis shows units of seconds, and the $\mathrm{y}$ axis arbitrary absorbance units. The second order $\mathrm{k}$ was determined to be $0.071 \mathrm{M}^{-1} \mathrm{sec}^{-1}$; fitting was also attempted to a simple first order exponential, but the fit was worse.

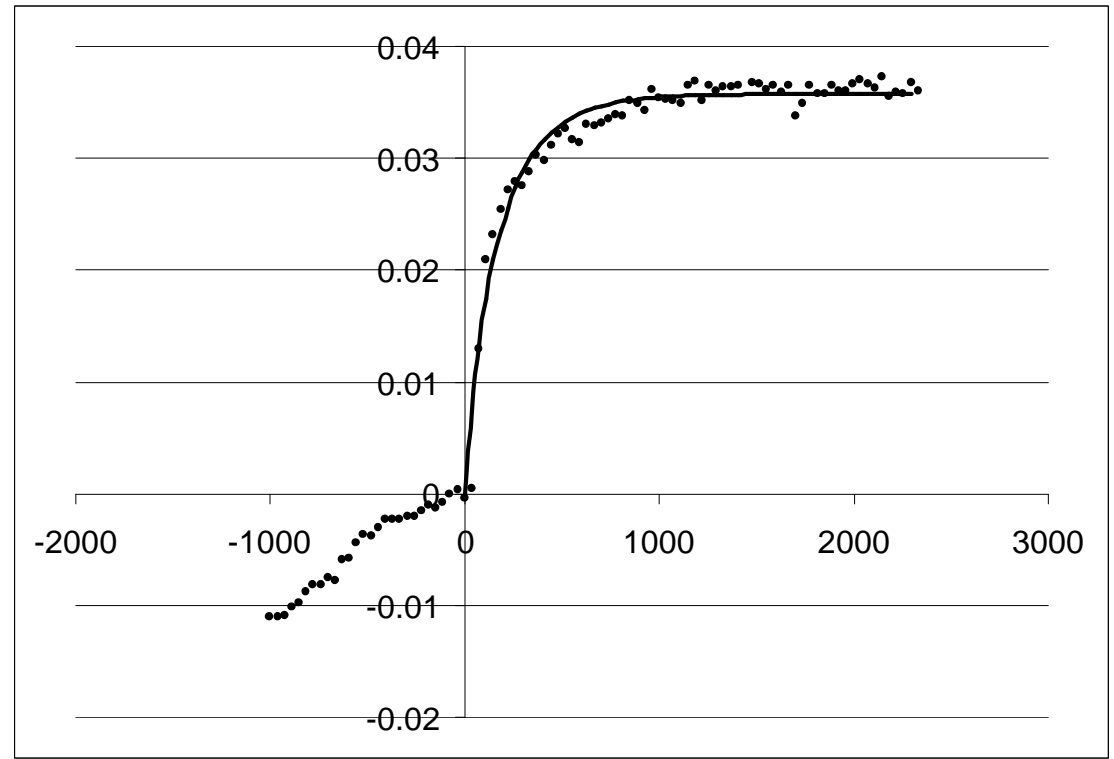


The appearance of $\mathrm{Na}_{2} \mathrm{Fe}(\mathrm{CO})_{4}$ was followed at $1881 \mathrm{~cm}^{-1}$, and the experimental data (diamonds) is shown with the fitted curve (solid line). The $\mathrm{x}$ axis shows units of seconds, and the $\mathrm{y}$ axis arbitrary absorbance units. The second order $\mathrm{k}$ was determined to be $0.12 \mathrm{M}^{-1} \mathrm{sec}^{-1}$; fitting was also attempted to a simple first order exponential, but the fit was worse.
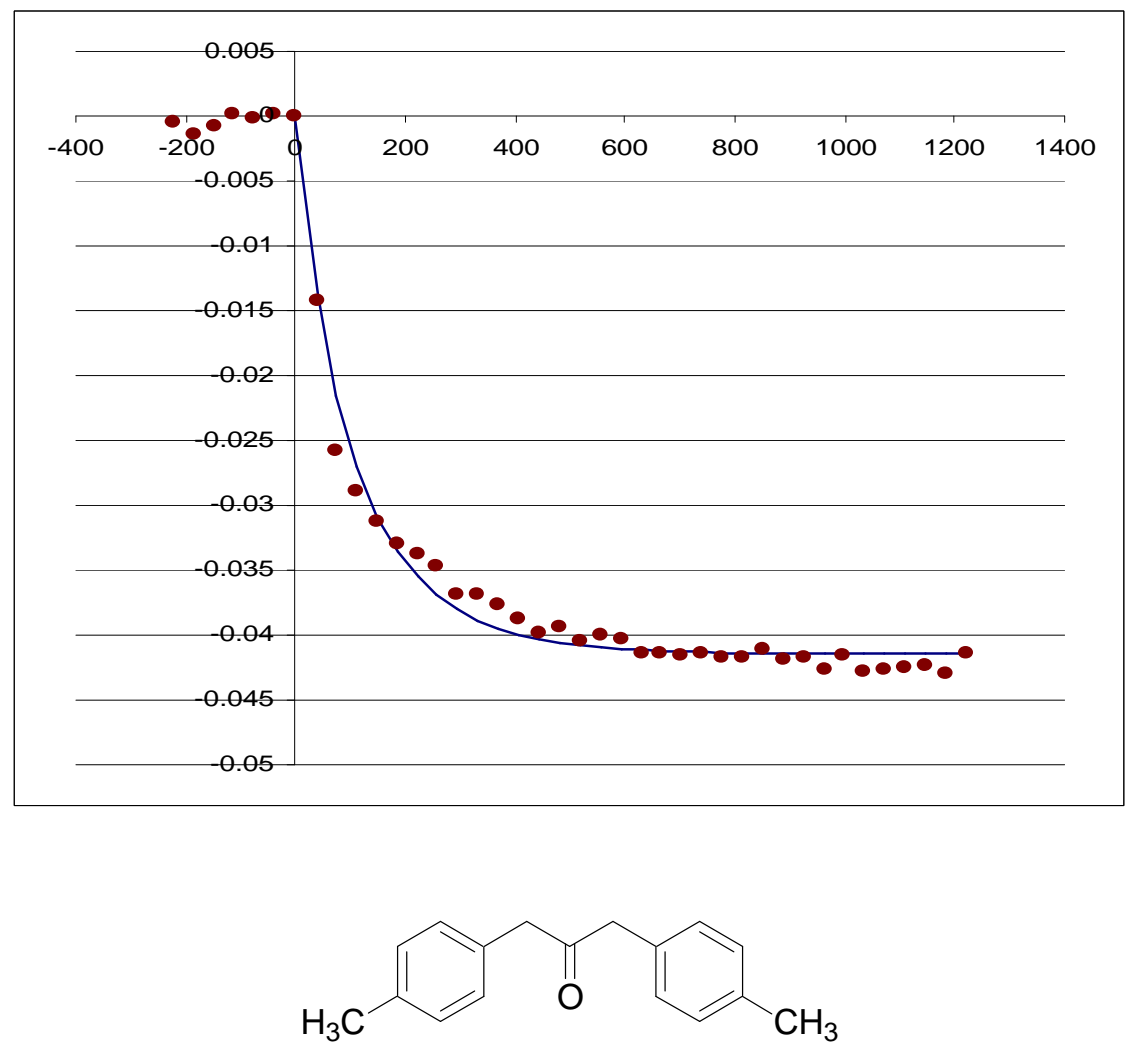

1,3-Bis-(4-methylphenyl)-propan-2-one ${ }^{7}$ (1e) $0.049 \mathrm{~g}(0.23 \mathrm{mmol})$ Collman salt was weighed out in a glove box and cooled to $0{ }^{\circ} \mathrm{C}$. $0.498 \mathrm{~g}$ 4-methylbenzylbromide $(2.6908 \mathrm{mmol}$ was dissolved in $25 \mathrm{ml}$ NMP and oxygen removed by several freeze pump thaw cycles. This solution was cooled to $0{ }^{\circ} \mathrm{C}$ and transferred to the flask containing the Collman salt. The reaction was then warmed to $50{ }^{\circ} \mathrm{C}$ and stirred for $30 \mathrm{hrs}$. After 30 hours the reaction was diluted in $4: 1$ hexanes:ether and poured over an equal volume of saturated ammonium chloride. The aqueous layer was extracted with $4100 \mathrm{ml}$ portions of $4: 1$ hexanes:ether. The reaction products were separated from residual reaction solvent and iron salts by column chromatography (5-10\% ethyl acetate in hexanes). The desired product was then isolated by another column (using either ethyl acetate in hexanes or straight toluene depending on which bromides were coupled). The product was isolated as white needle-like crystals. Nota bene: as few as 3 equivalents of the benzyl bromide can be used without reducing the yield. $(0.057 \mathrm{~g}, 94.2 \%$ yield with respect to recovered starting material). ${ }^{1} \mathrm{H}$ NMR $d 7.15(\mathrm{~d}, J=7.8 \mathrm{~Hz}, 4 \mathrm{H}), 7.06(\mathrm{~d}, J=7.8 \mathrm{~Hz}, 4 \mathrm{H}), 3.68(\mathrm{~s}, 4 \mathrm{H})$, $2.35(\mathrm{~s}, 6 \mathrm{H}) ;{ }^{13} \mathrm{C}$ NMR $d 206.11,136.58,130.96,129.35,129.31,48.54,21.02$; CI-GCMS: Calc. for $\mathrm{C}_{17} \mathrm{H}_{18} \mathrm{O}\left({ }^{+} \mathrm{M}+\mathrm{H}\right)$ : 239.1436, Found: 239.4 . 


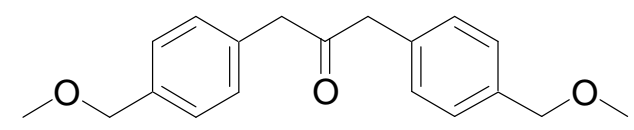

1,3-Bis-(4-methoxymethylphenyl)-propan-2-one (1a) The ketone was prepared in the manner described for compound 1e using $0.448 \mathrm{~g}$ of $\mathbf{6 a}$ and $0.149 \mathrm{~g}$ of iron tetracarbonyl disodium. $(0.109 \mathrm{~g}, 63.9 \%){ }^{1} \mathrm{H}$ NMR $d 7.29(\mathrm{~d}, J=8.2 \mathrm{~Hz}, 4 \mathrm{H}), 7.13(\mathrm{~d}, J=8.0 \mathrm{~Hz}, 4 \mathrm{H}), 4.44(\mathrm{~s}, 4 \mathrm{H}), 3.71$ $(\mathrm{s}, 4 \mathrm{H}), 3.39(\mathrm{~s}, 6 \mathrm{H}) ;{ }^{13} \mathrm{C}$ NMR $d 205.48,137.04,133.30,129.86,128.05,74.31,58.09,48.73$; IR (neat, $\mathrm{cm}^{-1}$ ): 2926.47, 1720.31, 1513.76, 1420.57, 1381.11, 1280.36, 1192.17, 1100.76, 1021.88, 967.48, 820.37 ; HR-FABMS: Calc. for $\mathrm{C}_{19} \mathrm{H}_{22} \mathrm{O}_{3} \mathrm{Li}\left({ }^{+} \mathrm{M}+\mathrm{Li}\right)$ : 305.1738, Found: 305.1737.

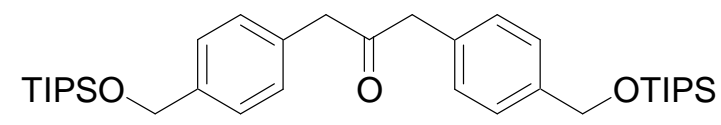

1,3-Bis-(4-(triisopropylsiloxyl)methylphenyl)-propan-2-one (1b) The ketone was prepared in the manner described for compound 1e using $0.298 \mathrm{~g}$ of $\mathbf{6 b}$ and $0.054 \mathrm{~g}$ of iron tetracarbonyl disodium. $(0.156 \mathrm{~g}, 89 \%){ }^{1} \mathrm{H}$ NMR $d 7.31(\mathrm{~d}, J=8.4 \mathrm{~Hz}, 4 \mathrm{H}), 7.11(\mathrm{~d}, J=8.2 \mathrm{~Hz}, 4 \mathrm{H}), 4.82(\mathrm{~s}$, $4 \mathrm{H}), 3.69(\mathrm{~s}, 4 \mathrm{H}), 1.21-1.12(\mathrm{~m}, 6 \mathrm{H}), 1.09(\mathrm{~d}, J=6.7 \mathrm{~Hz}, 36 \mathrm{H}) ;{ }^{13} \mathrm{C}$ NMR $d 206.01,140.50$, 132.39, 129.29, 126.08, 64.74, 48.71, 18.03, 12.01; IR (neat, $\mathrm{cm}^{-1}$ ): 2942.91, 2865.92, 1719.78, 1513.99, 1463.24, 1374.08, 1095.51, 1013.95, 882.53, 806.02, 682.31; HR-FABMS: Calc. for $\mathrm{C}_{35} \mathrm{H}_{58} \mathrm{O}_{3} \mathrm{Si}_{2} \mathrm{Li}\left({ }^{+} \mathrm{M}+\mathrm{Li}\right): 590.4140$, Found: 590.4135 .

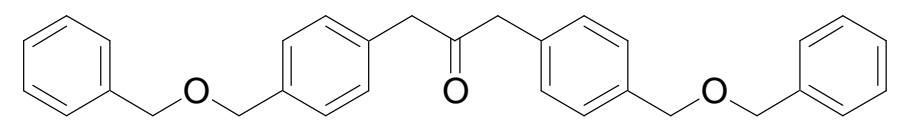

1,3-Bis-(4-phenylmethoxymethylphenyl)-propan-2-one (1c) The ketone was prepared in the manner described for compound 1e using $0.523 \mathrm{~g}$ of $\mathbf{6 c} .(0.177 \mathrm{~g}, 60 \%){ }^{1} \mathrm{H}$ NMR $d 7.40-7.27$ $(\mathrm{m}, 14 \mathrm{H}), 7.15(\mathrm{~d}, J=8.0 \mathrm{~Hz}, 4 \mathrm{H}), 4.57(\mathrm{~s}, 4 \mathrm{H}), 4.55(\mathrm{~s}, 4 \mathrm{H}), 3.72(\mathrm{~s}, 4 \mathrm{H}) ;{ }^{13} \mathrm{C} \mathrm{NMR} d 205.48$, 138.24, 137.20, 133.34, 129.53, 129.40, 128.14, 127.76, 127.64, 72.20, 71.79, 48.80; IR (neat, $\left.\mathrm{cm}^{-1}\right): 3034.14,2854.02,1703.37,1613.26,1514.28,1453.40,1411.51,1353.59,1305.38$, $1282.07,1232.80,1213.33,1185.61,1081.51,1059.54,1023.14,911.05,858.03,828.00,789.43$, 755.61, 738.86, 694.40, 676.81, 603.94, 575.29; FABMS Calc. for $\mathrm{C}_{31} \mathrm{H}_{30} \mathrm{O}_{3} \mathrm{Li}\left({ }^{+} \mathrm{M}+\mathrm{Li}\right)$ : 458.2383, Found: 458.2377.

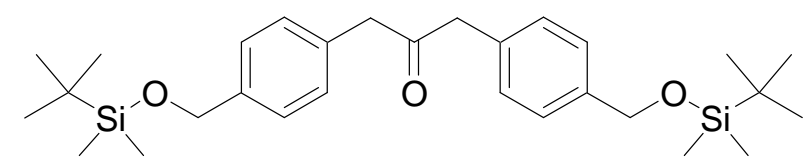

1,3-Bis-(4-(tert-butyldimethylsiloxyl)methylphenyl)-propan-2-one (1d) The ketone was prepared in the manner described for compound 1e using $0.329 \mathrm{~g}$ of $\mathbf{6 d} .(0.044 \mathrm{~g}, 65 \%){ }^{1} \mathrm{H}$ NMR $d 7.29(\mathrm{~d}, J=8.0 \mathrm{~Hz}, 4 \mathrm{H}), 7.12(\mathrm{~d}, J=8.2 \mathrm{~Hz}, 4 \mathrm{H}), 4.74(\mathrm{~s}, 4 \mathrm{H}), 3.70(\mathrm{~s}, 4 \mathrm{H}), 0.96$ (s, $18 \mathrm{H}), 0.11(\mathrm{~s}, 12 \mathrm{H}) ;{ }^{13} \mathrm{C} \mathrm{NMR} d 205.78,140.28,132.57,129.33,126.41,64.69,48.72,25.94$, 18.39, -5.21; IR (neat, $\mathrm{cm}^{-1}$ ): 2955.02, 2928.38, 2885.11, 2856.48, 1718.92 (s), 1515.36, 
1471.96, 1256.92, 1093.40, 838.09, 776.54; HR-FABMS Calc. for $\mathrm{C}_{29} \mathrm{H}_{46} \mathrm{Si}_{2} \mathrm{O}_{3} \mathrm{Li}\left({ }^{+} \mathrm{M}+\mathrm{Li}\right)$ : 506.3170, Found: 506.3163 .

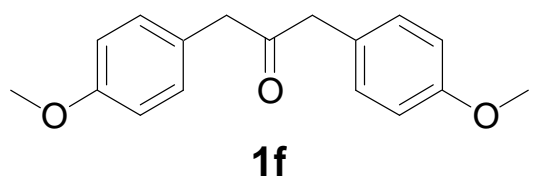

1,3-Bis-(4-methoxyphenyl)-propan-2-one ${ }^{7}$ (1f) The ketone was prepared in the manner described for compound 1e using $0.240 \mathrm{~g}$ of 4-methoxybenzyl bromide and $0.045 \mathrm{~g}$ of iron tetracarbonyl disodium. $(0.062 \mathrm{~g}, 82.6 \%){ }^{1} \mathrm{H}$ NMR $d 7.08(\mathrm{~d}, J=8.6 \mathrm{~Hz}, 4 \mathrm{H}), 6.86(\mathrm{~d}, J=8.8$ $\mathrm{Hz}, 4 \mathrm{H}), 3.80(\mathrm{~s}, 6 \mathrm{H}), 3.64(\mathrm{~s}, 4 \mathrm{H}) ;{ }^{13} \mathrm{C}$ NMR $d 206.38,158.62,130.45,126.08,114.10,55.20$, 48.00; IR (neat, $\mathrm{cm}^{-1}$ ): 2930.15, 1701.47, 1607.84, 1581.52, 1509.44, 1456.65, 1444.80, 1281.57, $1241.98,1179.85,1115.23,1064.28,1025.09,818.95,790.47,716.67,669.34$.<smiles>O=C(Cc1ccc(Br)cc1)Cc1ccc(Br)cc1</smiles>

1,3-Bis-(4-bromophenyl)-propan-2-one ${ }^{8}(\mathbf{1 g})$ The ketone was prepared in the manner described for compound 1e using $1.008 \mathrm{~g}$ of 4-bromobenzyl bromide and $0.200 \mathrm{~g}$ of iron tetracarbonyl disodium. $(0.217 \mathrm{~g}, 76.7 \%){ }^{1} \mathrm{H}$ NMR $d 7.44(\mathrm{~d}, J=8.4 \mathrm{~Hz}, 4 \mathrm{H}), 7.01(\mathrm{~d}, J=8.2$ $\mathrm{Hz}, 4 \mathrm{H}$ ), 3.68 (s, 4H); ${ }^{13} \mathrm{C}$ NMR $d 205.43,132.57,131.84,131.15,121.25,48.43$; IR (neat, $\mathrm{cm}^{-}$ $\left.{ }^{1}\right): 2885.74,1716.31,1487.00,1415.91,1339.28,1102.14,1055.44,1010.93,839.07,827.07$, 790.95, 729.31, 675.96; FAB HRMS Calc. for $\mathrm{C}_{15} \mathrm{H}_{12} \mathrm{LiBrO}_{2}\left({ }^{+} \mathrm{M}+\mathrm{Li}\right): 372.9415$, Found: 372.9405 .<smiles>CC(=O)c1ccc(CC(=O)Cc2ccc(C(C)=O)cc2)cc1</smiles>

1,3-Bis-(4-(methoxycarbonyl)phenyl)-propan-2-one' (1i) The ketone was prepared in the manner described for compound 1e using $0.534 \mathrm{~g}$ of 4-bromomethyl-benzoic acid methyl ester and $0.130 \mathrm{~g}$ of iron tetracarbonyl disodium. Nota bene: traces of 1,2-bis-(4-

(methoxycarbonyl)phenyl)-ethane were present in the crude reaction mixture. $(0.040 \mathrm{~g}, 37.2 \%)$ ${ }^{1} \mathrm{H}$ NMR $d 7.99(\mathrm{~d}, J=8.6 \mathrm{~Hz}, 4 \mathrm{H}), 7.21(\mathrm{~d}, J=8.6 \mathrm{~Hz}, 4 \mathrm{H}), 3.91(\mathrm{~s}, 6 \mathrm{H}), 3.80(\mathrm{~s}, 4 \mathrm{H}) ;{ }^{13} \mathrm{C}$ NMR $d$ 203.67, 166.76, 138.73, 130.02, 129.55, 52.12, 49.20

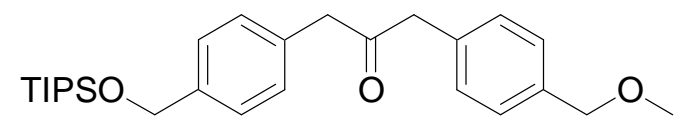


(0.98 mmol) in $7 \mathrm{ml} \mathrm{NMP}$ was cooled to $0{ }^{\circ} \mathrm{C}$, deoxygenated for 30 minutes (by bubbling nitrogen through the solution) and added to the $\mathrm{Na}_{2} \mathrm{Fe}(\mathrm{CO})_{4}$ via cannula. The resulting solution was removed warmed to room temperature and stirred for 90 minutes. A solution of $1.143 \mathrm{~g}$ $(5.31 \mathrm{mmol})$ of $\mathbf{6 b}$ in $10 \mathrm{ml}$ NMP was deoxygenated for one hour and added to the reaction mixture. The resulting solution was then warmed to $45^{\circ} \mathrm{C}$ and stirred overnight. After $18 \mathrm{hrs}$ of stirring under nitrogen, the reaction was diluted in 4:1 hexanes:ether and poured over an equal volume of saturated ammonium chloride. The aqueous layer was extracted with $4100 \mathrm{ml}$ portions of 4:1 hexanes:ether. The reaction products are separated from residual reaction solvent and iron salts by column chromatography (10\% ethyl acetate in hexanes). The desired product can be isolated with another column (3\% ethyl acetate in hexanes) as a colorless oil. $(0.321 \mathrm{~g}$, 74.0\% yield with respect to 6a) ${ }^{1} \mathrm{H}$ NMR $d$ 7.33-7.27 (m, 4H), 7.15-7.11 (m, 4H), 4.83(s, 2H), 4.45 (s, 2H), $3.71(\mathrm{~s}, 2 \mathrm{H}), 3.70(\mathrm{~s}, 2 \mathrm{H}), 3.39(\mathrm{~s}, 3 \mathrm{H}), 1.23-1.15(\mathrm{~m}, 3 \mathrm{H}), 1.10(\mathrm{~d}, J=6.7 \mathrm{~Hz}$, $18 \mathrm{H}) ;{ }^{13} \mathrm{C}$ NMR $d$ 205.70, 140.54, 136.99, 133.40, 132.30, 129.50, 129.26, 128.04, 126.09, 74.34, 64.72, 58.08, 48.83, 48.62, 18.02, 12.01; IR (neat, $\mathrm{cm}^{-1}$ ): 2926.02, 2864.67, 1717.98, 1513.92, 1459.11, 1420.70, 1381.02, 1331.09, 1212.81, 1192.49, 1099.59, 1021.87, 818.07; FAB HRMS Calc. for $\mathrm{C}_{27} \mathrm{H}_{40} \mathrm{LiO}_{3} \mathrm{Si}\left({ }^{+} \mathrm{M}+\mathrm{Li}\right)$ : 447.2907, Found: 447.2895.

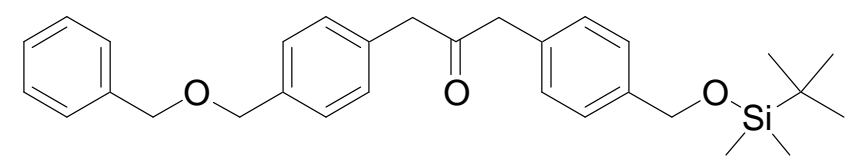

1-(4-(tert-butyldimethylsiloxyl)methylphenyl)-3-(4-phenylmethoxymethylphenyl)-propan-2one (1k) The ketone was prepared in the manner described for compound $\mathbf{1 j}$ using $0.308(0.977$ $\mathrm{mmol})$ of $\mathbf{6 d}$ as the first halide added and $0.557 \mathrm{~g}(1.91 \mathrm{mmol}) \mathbf{6 c}$ as the second halide. $(0.152$, 65\%) ${ }^{1} \mathrm{H}$ NMR $d 7.37-7.25(\mathrm{~m}, 9 \mathrm{H}), 7.15-7.10(\mathrm{~m}, 4 \mathrm{H}), 4.73(\mathrm{~s}, 2 \mathrm{H}), 4.56(\mathrm{~s}, 2 \mathrm{H}), 4.54(\mathrm{~s}, 2 \mathrm{H})$, $3.71(\mathrm{~s}, 2 \mathrm{H}), 3.70(\mathrm{~s}, 2 \mathrm{H}), 0.95(\mathrm{~s}, 9 \mathrm{H}), 0.10(\mathrm{~s}, 6 \mathrm{H}) ;{ }^{13} \mathrm{C}$ NMR $d$ 205.68, 140.34, 138.23, 137.13, 133.39, 132.50, 129.54, 129.33, 128.40, 128.12, 127.76, 127.64, 126.44, 72.17, 71.78, 64.68, 48.85, 48.66, 25.94, 18.40, -5.26; IR (neat, $\mathrm{cm}^{-1}$ ): 2926.99, 2851.59, 1705.29, 1460.43, 1380.53, 1358.99, 1306.69, 1246.72, 1209.93, 1094.02, 1017.38, 837.07, 795.64, 768.61, 733.51, 701.36, 517.01; FAB HRMS: Calc. for $\mathrm{C}_{30} \mathrm{H}_{38} \mathrm{O}_{3} \mathrm{SiLi}\left({ }^{+} \mathrm{M}+\mathrm{Li}\right)$ : 481.2745, Found: 481.2754.

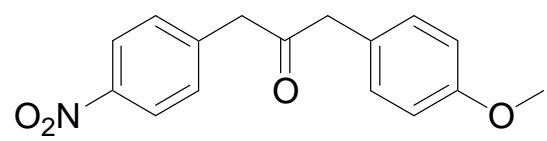

1-(4-(methoxyphenyl)-3-(4-nitrophenyl)-propan-2-one ${ }^{\mathbf{1 0}}$ (11) The ketone was prepared in the manner described for compound 1j. IR (neat, $\mathrm{cm}^{-1}$ ): 2934.58, 1701.75, 1607.33, 1581.59, 1509.27, 1456.34, 1339.99, 1242.41, 1179.83, 1025.71, 819.18, 789.42 697.23, 669.09

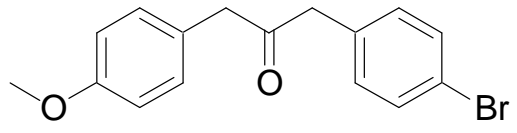


1-(4-(bromophenyl)-3-(4-methoxyphenyl)-propan-2-one (1m) The ketone was prepared in the manner described for compound $\mathbf{1 j}$ using 0.481 (1.92 $\mathrm{mmol})$ of 1-bromomethyl-4-bromobenzene as the first halide added and $0.668 \mathrm{~g}(3.32 \mathrm{mmol})$ of 1-bromomethyl-4-methoxybenzene as the second halide. $(0.387 \mathrm{~g}, 63 \%) ;{ }^{1} \mathrm{H}$ NMR $d 7.43(\mathrm{~d}, J=8.3 \mathrm{~Hz}, 2 \mathrm{H}), 7.07(\mathrm{~d}, J=8.3 \mathrm{~Hz}, 2 \mathrm{H})$, $6.99(\mathrm{~d}, J=8.3 \mathrm{~Hz}, 2 \mathrm{H}), 6.86(\mathrm{~d}, J=8.3 \mathrm{~Hz}, 2 \mathrm{H}), 3.80(\mathrm{~s}, 3 \mathrm{H}), 3.66(\mathrm{~s}, 4 \mathrm{H}) ;{ }^{13} \mathrm{C} \mathrm{NMR} d$ 205.14, 158.76, 132.96, 131.68, 131.17, 130.45, 125.68, 121.01, 114.23, 55.25, 48.56, 47.91; IR (neat, $\mathrm{cm}^{-1}$ ): $2887.91,1714.46,1612.46,1514.74,1486.47,1454.73,1416.77,1342.25,1301.54$, 1247.14, 1177.46, 1036.24, 1009.35, 842.44, 805.89, 726.07, 668.88, 621.96; FAB HRMS Calc. for $\mathrm{C}_{16} \mathrm{H}_{15} \mathrm{LiBrO}_{2}\left({ }^{+} \mathrm{M}+\mathrm{Li}\right)$ : 325.0415 , Found: 325.0401 .

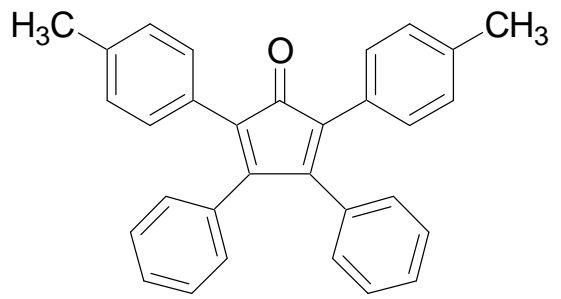

2,5-bis-(4-methylphenyl)-3,4-diphenylcyclopenta-2,4-dieneone ${ }^{11}$ (2a) $\quad 0.074 \mathrm{~g}$ of $1 \mathrm{1e}(0.310$ $\mathrm{mmol}), 0.184 \mathrm{~g}$ of benzil $(0.875 \mathrm{mmol})$, and $0.019 \mathrm{~g}$ of potassium hydroxide were dissolved in $10 \mathrm{ml}$ of ethanol and brought to reflux for 2 hours prior to cooling to room temperature and quenching in dilute acid (saturated ammonium chloride in $0.5 \% \mathrm{HCl}$ ). The aqueous layer was extracted with three portions of hexanes. Flash chromatography (5\% ethyl acetate in hexanes) yielded 2a as a bright purple crystalline solid. (0.112g, 87.5\%); m.p.: $175{ }^{\circ} \mathrm{C},{ }^{1} \mathrm{H}$ NMR $d 7.28$ $7.23(\mathrm{~m}, 2 \mathrm{H}), 7.21-7.15(\mathrm{~m}, 8 \mathrm{H}), 7.09-7.04(\mathrm{~m}, 4 \mathrm{H}), 6.99-6.94(\mathrm{~m}, 4 \mathrm{H}), 2.33(\mathrm{~s}, 6 \mathrm{H}) ;{ }^{13} \mathrm{C}$ NMR $d$ 200.73, 153.82, 137.22, 133.85, 129.99, 129.30, 128.78, 128.30, 127.94 127.88, 125.10, 21.29; IR (neat, $\mathrm{cm}^{-1}$ ): 2917.39, 1709.09, 1511.75, 1441.46, 1356.46, 1303.23, 1186.71, 1113.98, $1073.37,1027.88,919.66,834.26,795.86,776.50,740.41,700.09$

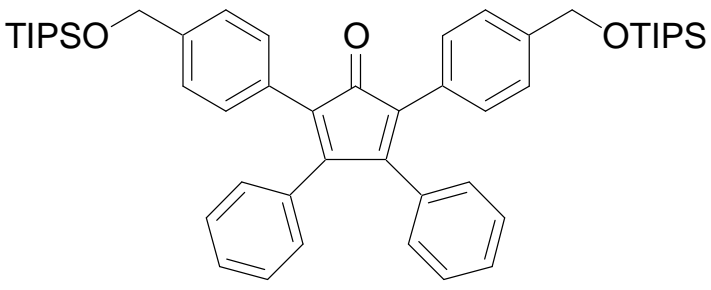

2,5-bis-(4-(triisopropylsiloxymethyl)phenyl)-3,4-diphenylcyclopenta-2,4-dienone (2b) The cyclopentadienone was prepared in the manner described for $\mathbf{2 a}$ using $0.110 \mathrm{~g}$ of $\mathbf{1 b}$ and $0.131 \mathrm{~g}$ of benzil $(0.128 \mathrm{~g}, 90.1 \%)$ m.p.: $141{ }^{\circ} \mathrm{C},{ }^{1} \mathrm{H}$ NMR $d 7.31-7.25(\mathrm{~m}, 10 \mathrm{H}), 7.23-7.18(\mathrm{~m}, 4 \mathrm{H})$, $6.99-6.96(\mathrm{~m}, 4 \mathrm{H}), 4.85(\mathrm{~s}, 4 \mathrm{H}), 1.25-1.17(\mathrm{~m}, 6 \mathrm{H}), 1.12(\mathrm{~d}, J=6.9 \mathrm{~Hz}, 36 \mathrm{H}) ;{ }^{13} \mathrm{C} \mathrm{NMR} d$ 200.59, 154.10, 140.89, 133.26, 129.95, 129.35, 127.92, 125.38, 125.18, 64.87, 18.04, 12.05; IR (neat): 2942.6, 2865.09, 1707.69, 1461.15, 1373.37, 1096.28, 993.75, 881.08, 794.25, 682.98; MALDI-HRMS Calc. for $\mathrm{C}_{40} \mathrm{H}_{43} \mathrm{O}_{2} \mathrm{Si}$ ( $\left.{ }^{+} \mathrm{M}-\mathrm{OTIPS}\right):$ 583.3032, Found: 583.3006. 


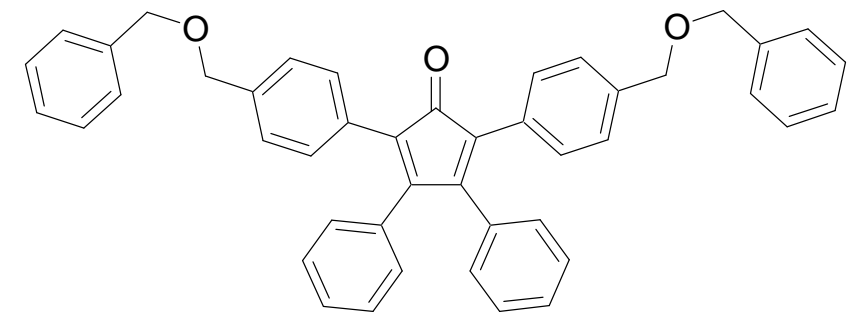

2,5-bis-(4-(phenylmethoxymethyl)phenyl)-3,4-diphenylcyclopenta-2,4-dienone (2c) The cyclopentadienone was prepared in the manner described for $2 \mathrm{a}$ using $0.233 \mathrm{~g}$ of $1 \mathrm{c}$ and $0.424 \mathrm{~g}$ of benzil $(0.192 \mathrm{~g}, 59.4 \%)$ m.p.: $149^{\circ} \mathrm{C},{ }^{1} \mathrm{H}$ NMR $d 7.37-7.34(\mathrm{~m}, 8 \mathrm{H}), 7.25-7.22(\mathrm{~m}, 11 \mathrm{H})$, $7.19-7.14(\mathrm{~m}, 5 \mathrm{H}), 6.94-6.91(\mathrm{~m}, 4 \mathrm{H}), 4.56(\mathrm{~s}, 4 \mathrm{H}), 4.52(\mathrm{~s}, 4 \mathrm{H}) ;{ }^{13} \mathrm{C}$ NMR $d 200.38,154.50$, $138.22,137.49,133.08,130.14,130.09,129.29,128.48,128.01,127.64,127.42,127.28,125.04$, 124.12, 72.29, 71.90. FAB-HRMS Calc. for $\mathrm{C}_{45} \mathrm{H}_{36} \mathrm{O}_{3} \mathrm{Li}\left({ }^{+} \mathrm{M}+\mathrm{Li}\right): 632.2853$, Found: 632.2853.

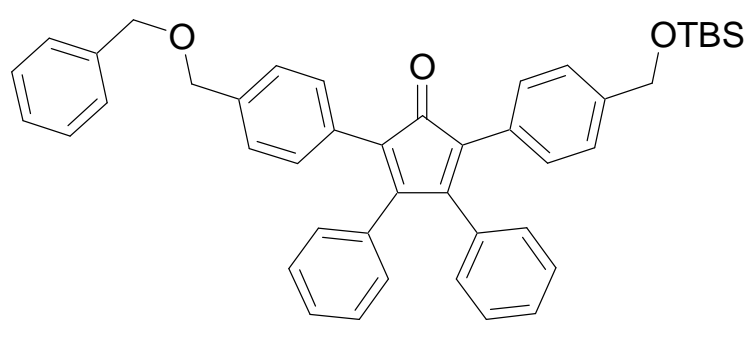

2-(4-(tert-butyldimethylsiloxyl)methylphenyl)-5-(4-(phenylmethoxymethyl)phenyl)-3,4diphenylcyclopenta-2,4-dienone (2d) The cyclopentadienone was prepared in the manner described for $\mathbf{2 a}$ using $0.324 \mathrm{~g}$ of $\mathbf{1 k}$ and $0.293 \mathrm{~g}$ of benzil $(0.285 \mathrm{~g}, 64.3 \%)$ m.p.: $119{ }^{\circ} \mathrm{C},{ }^{1} \mathrm{H}$ NMR $d 7.40-7.36(\mathrm{~m}, 6 \mathrm{H}), 7.34-7.27(\mathrm{~m}, 4 \mathrm{H}), 7.25-7.22(\mathrm{~m}, 5 \mathrm{H}), 7.21-7.16(\mathrm{~m}, 4 \mathrm{H}), 6.97$ $-6.93(\mathrm{~m}, 4 \mathrm{H}), 4.73(\mathrm{~s}, 2 \mathrm{H}), 4.58(\mathrm{~s}, 2 \mathrm{H}), 4.54(\mathrm{~s}, 2 \mathrm{H}), 0.95(\mathrm{~s}, 9 \mathrm{H}), 0.11(\mathrm{~s}, 6 \mathrm{H}) ;{ }^{13} \mathrm{C} \mathrm{NMR} d$ 200.43, 154.56 (2C), 140.70, 138.26, 137.48, 133.21, 130.16, 130.15, 129.99, 129.36, 129.34, $129.29,129.00,128.38,128.00,127.96,127.80,127.78,127.62,127.39,127.24,125.71,125.00$ (2C), 72.29, 71.92, 64.81, 25.96, 18.41, -5.26; IR (neat, $\left.\mathrm{cm}^{-1}\right): 2926.99,2851.99,1705.29$, 1460.43, 1380.53, 1358.99, 1306.69, 1246.72, 1209.93, 1094.02, 1017.38, 837.07, 795.64, 768.61, 733.51, 701.36; FAB-HRMS Calc. for $\mathrm{C}_{44} \mathrm{H}_{44} \mathrm{SiO}_{3} \mathrm{Li}\left({ }^{+} \mathrm{M}+\mathrm{Li}\right)$ : 656.3275 , Found: 656.3266 .

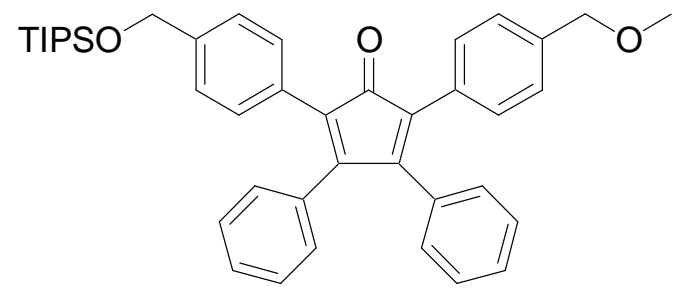

2-(4-(triisopropylsiloxymethyl)phenyl)-5-(4-(methoxymethyl)phenyl)-3,4diphenylcyclopenta-2,4-dienone (2e) The cyclopentadienone was prepared in the manner described for $\mathbf{2 a}$ using $0.212 \mathrm{~g}$ of $\mathbf{1} \mathbf{j}$ and $0.132 \mathrm{~g}$ of benzil $(0.170 \mathrm{~g}, 77 \%)$ m.p.: $133{ }^{\circ} \mathrm{C},{ }^{1} \mathrm{H}$ 
NMR $d 7.24-7.20(\mathrm{~m}, 10 \mathrm{H}), 7.19-7.14(\mathrm{~m}, 4 \mathrm{H}), 6.94-6.91(4 \mathrm{H}), 4.80(\mathrm{~s}, 2 \mathrm{H}), 4.41(\mathrm{~s}, 2 \mathrm{H})$, $3.38(\mathrm{~s}, 3 \mathrm{H}), 1.20-1.11(\mathrm{~m}, 3 \mathrm{H}), 1.08(\mathrm{~d}, J=6.4 \mathrm{~Hz}, 18 \mathrm{H}) ;{ }^{13} \mathrm{C}$ NMR $d 200.3,154.5,140.2$, $137.4,133.0,130.2$, 130.1, 130.0, 129.2, 128.4, 128.0, 127.3, 126.6, 125.0, 74.43, 64.93, 58.15, 18.00, 12.10; IR (neat): 2923.64, 1707.82, 1442.27, 1016.19, 907.90, 835.05, 729.24, 695.82; FAB-HRMS Calc. for $\mathrm{C}_{41} \mathrm{H}_{46} \mathrm{SiO}_{3} \mathrm{Li}\left({ }^{+} \mathrm{M}+\mathrm{Li}\right)$ : 622.3408, Found: 622.3408 .

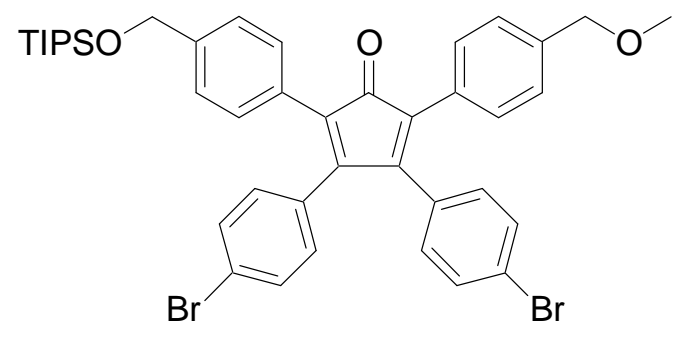

2-(4-(triisopropylsiloxymethyl)phenyl)-5-(4-(methoxymethyl)phenyl)-3,4-bis-(4bromophenyl)cyclopenta-2,4-dienone (2f) The cyclopentadienone was prepared in the manner described for $\mathbf{2 a}$ using $0.041 \mathrm{~g}$ of $\mathbf{1} \mathbf{j}$ and $0.047 \mathrm{~g}$ of 4,4'-dibromobenzil $(0.054 \mathrm{~g}, 75.1 \%)$ m.p.: $144{ }^{\circ} \mathrm{C},{ }^{1} \mathrm{H}$ NMR $d 7.34(\mathrm{~d}, J=8.4 \mathrm{~Hz}, 2 \mathrm{H}), 7.34(\mathrm{~d}, J=8.6 \mathrm{~Hz}, 2 \mathrm{H}), 7.26(\mathrm{~d}, J=8.4 \mathrm{~Hz}, 4 \mathrm{H})$, $7.24(\mathrm{~d}, J=8.4 \mathrm{~Hz}, 4 \mathrm{H}), 7.20-7.16(\mathrm{~m}, 4 \mathrm{H}), 6.80(\mathrm{~d}, J=8.4 \mathrm{~Hz}, 4 \mathrm{H}), 6.79(\mathrm{~d}, J=8.6 \mathrm{~Hz}$, $4 \mathrm{H}), 4.82(\mathrm{~s}, 2 \mathrm{H}), 4.43(\mathrm{~s}, 2 \mathrm{H}), 3.40(\mathrm{~s}, 3 \mathrm{H}), 1.21-1.14(\mathrm{~m}, 3 \mathrm{H}), 1.09(\mathrm{~d}, J=6.7 \mathrm{~Hz}, 18 \mathrm{H}) ;{ }^{13} \mathrm{C}$ NMR $d$ 199.66, 152.61, 152.06, 141.42, 137.82, 131.75, 131.72, 131.50, 131.45, 131.24, 130.94, $130.88,130.08,129.88,129.58,128.57,127.46,125.86,125.53,123.06,123.00,74.40,64.76$, 58.30, 18.03, 12.00; IR (neat, $\mathrm{cm}^{-1}$ ): 2923.89, 2863.61, 1711.30, 1585.40, 1483.72, 1461.76, 1379.74, 1209.19, 1094.60, 1076.43, 1009.36, 881.53, 795.49, 681.15; MALDI FTMS Calc. for $\mathrm{C}_{41} \mathrm{H}_{44} \mathrm{SiBr}_{2} \mathrm{O}_{3}\left({ }^{+} \mathrm{M}-\mathrm{H}\right):$ 769.1348, Found: 769.1328 .

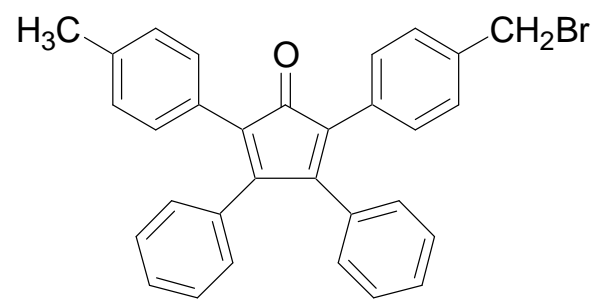

2-(4-methylphenyl)-5-(4-(bromomethyl)phenyl)-3,4-diphenylcyclopenta-2,4-dienone (2g) $0.039 \mathrm{~g}$ of $2 \mathbf{a}(0.09 \mathrm{mmol})$ and $0.021 \mathrm{~g}$ of NBS $(0.1 \mathrm{mmol})$ were dissolved in $30 \mathrm{ml}$ of carbon tetrachloride and brought to reflux under radiation of a 275 watt broadband UV lamp. Reflux and irradiation continued for 24 hours prior to dilution in ether and extraction with water. Column chromatography ( $2.5 \%$ ethyl acetate in hexanes) gave $0.015 \mathrm{~g}$ of $\mathbf{2 g}$ (32\% yield) as well as $0.011 \mathrm{~g}$ of the dibrominated product $(20 \%$ yield) and $0.007 \mathrm{~g}$ of recovered starting material (18\%) all as purple crystalline solids. $2 \mathrm{~g}:$ m.p.: $175^{\circ} \mathrm{C},{ }^{1} \mathrm{H}$ NMR $d 7.28-7.21(\mathrm{~m}, 5 \mathrm{H}), 7.21-$ $7.15(\mathrm{~m}, 5 \mathrm{H}), 7.13(\mathrm{~d}, J=8.2 \mathrm{~Hz}, 2 \mathrm{H}), 7.05(\mathrm{~d}, J=8.2 \mathrm{~Hz}, 2 \mathrm{H}), 6.94-6.91(\mathrm{~m}, 4 \mathrm{H}), 4.45(\mathrm{~s}$, 2H), $2.31(\mathrm{~s}, 3 \mathrm{H}) ;{ }^{13} \mathrm{C} \mathrm{NMR} d 200.34,155.29,153.61,137.44,136.62,133.16,133.06,131.06$, $130.40,129.98,129.29,129.20,128.83,128.75,128.59,128.40,128.07,127.98,127.67,125.44$, $124.37,33.44,21.29$. 


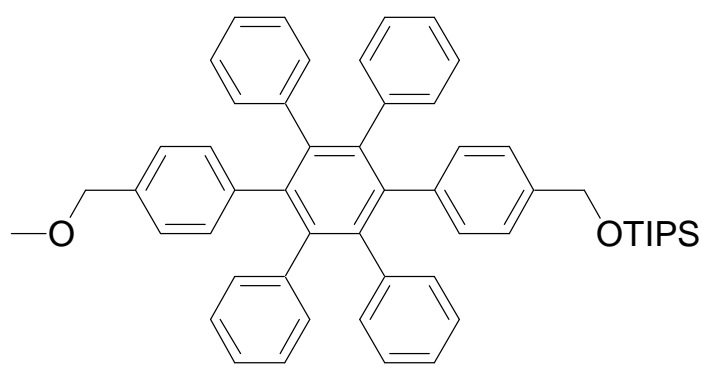

1-(4-(triisopropyl)siloxymethylphenyl)-4-(4-methoxymethylphenyl)-2,3,5,6-

tetraphenylbenzene $(\mathbf{4 a}) \quad(86.3 \%) \quad 0.027 \mathrm{~g}$ of $\mathbf{2 e}, 0.018 \mathrm{~g}$ diphenylethyne and $0.5 \mathrm{~g}(.5 \mathrm{ml})$ diphenyl ether were flushed with inert gas and then heated to reflux over a period of $15 \mathrm{~min}$. The reaction was refluxed for 19 hours prior to cooling to room temperature. The entire mixture was purified by flash chromatography (0\%-20\% ethyl acetate in hexanes). $(0.029 \mathrm{~g}, 86.3 \%){ }^{1} \mathrm{H}$ NMR $d 6.85-6.79(\mathrm{~m}, 26 \mathrm{H}), 6.78-6.75(\mathrm{~m}, 2 \mathrm{H}), 4.58(\mathrm{~s}, 2 \mathrm{H}), 4.24(\mathrm{~s}, 2 \mathrm{H}), 3.15(\mathrm{~s}, 3 \mathrm{H}), 1.09$ $1.03(\mathrm{~m}, 3 \mathrm{H}), 0.99(\mathrm{~d}, J=6.4 \mathrm{~Hz}, 18 \mathrm{H}) ;{ }^{13} \mathrm{C}$ NMR $\left(\mathrm{C}_{6} \mathrm{D}_{6}\right) d$ 141.32, 141.27, 141.20, 141.15, $140.99,140.40,139.80,139.11,136.08,134.41,131.80,131.76,129.99,129.03,127.25,127.21$, $126.53,125.77,125.74,124.86,74.11,65.09,57.17,18.19,12.32$; IR (neat, $\mathrm{cm}^{-1}$ ): 2863.98 , 1599.96, 1441.40, 1379.80, 1092.99, 1022.17, 881.27, 774.09, 696.20; FAB HRMS Calc. for $\mathrm{C}_{54} \mathrm{H}_{56} \mathrm{LiSiO}_{2}\left({ }^{+} \mathrm{M}+\mathrm{Li}\right):$ 771.4210, Found: 771.4225.

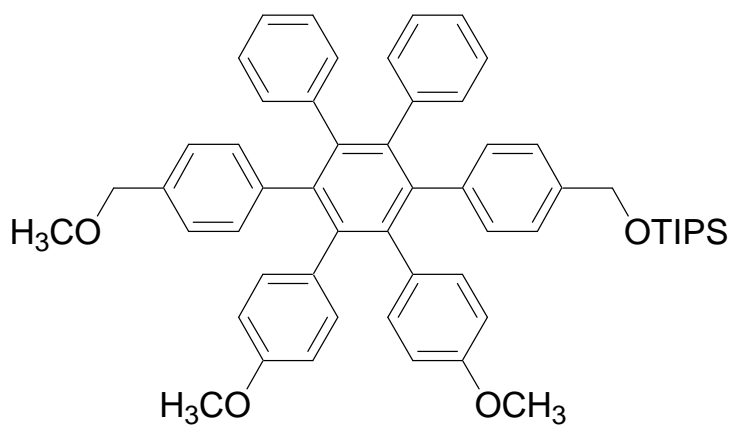

1-(4-(triisopropyl)siloxymethylphenyl)-4-(4-methoxymethylphenyl)-2,3-bis(4-

methoxyphenyl)-5,6-diphenylbenzene (4b) The tetraarylbenzene was prepared in the same manner as that described for $4 \mathbf{a}$ using $0.210 \mathrm{~g} \mathbf{2 e}$ and $0.105 \mathrm{~g}$ 1,2-bis(4-methoxyphenyl)ethyne. $(0.226 \mathrm{~g}, 80.2 \%){ }^{1} \mathrm{H}$ NMR $d 6.86-6.79(\mathrm{~m}, 16 \mathrm{H}), 6.76(\mathrm{~d}, J=8.2 \mathrm{~Hz}, 2 \mathrm{H}), 6.73-6.70(\mathrm{~m}, 4 \mathrm{H})$, $6.43-6.39(\mathrm{~m}, 4 \mathrm{H}), 4.61(\mathrm{~s}, 2 \mathrm{H}), 4.24(\mathrm{~s}, 2 \mathrm{H}), 3.61(\mathrm{~s}, 3 \mathrm{H}), 3.60(\mathrm{~s}, 3 \mathrm{H}), 3.17(\mathrm{~s}, 3 \mathrm{H}), 1.13-1.05$ $(\mathrm{m}, 3 \mathrm{H}), 1.01(\mathrm{~d}, J=6.6 \mathrm{~Hz}, 18 \mathrm{H}) ;{ }^{13} \mathrm{C}$ NMR $(318 \mathrm{~K}) d 156.89,156.87,140.76,140.72,140.61$, $140.41,140.26,140.24,140.16,140.10,140.08,139.20,138.16,134.43,133.16,133.14,132.41$, $132.38,131.44,131.38,131.13,126.49,126.21,125.02,124.97,124.01,112.14$ (2C), 74.35, 64.78, 57.27, 54.82, 54.78, 17.96, 11.97; IR (neat, $\mathrm{cm}^{-1}$ ):2864.18, 1609.99, 1515.55, 1462.31, $1287.69,1244.00,1175.70,1092.07,1031.17,1031.17,881.87,784.07,698.40$; FAB HRMS Calc. for $\mathrm{C}_{56} \mathrm{H}_{60} \mathrm{LiSiO}_{4}\left({ }^{+} \mathrm{M}+\mathrm{Li}\right): 831.4421$, Found: 831.4410. 


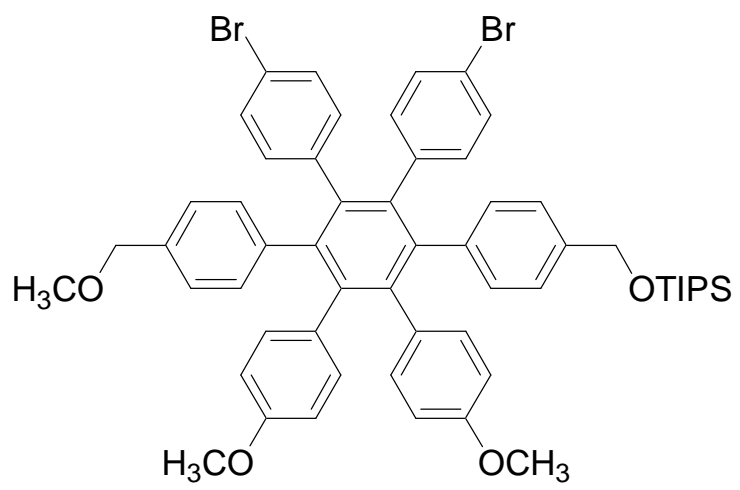

1-(4-(triisopropyl)siloxymethylphenyl)-4-(4-methoxymethylphenyl)-2,3-bis-(4-

methoxyphenyl)-5,6-bis-(4-bromophenyl)benzene (4c) The tetraarylbenzene was prepared in the same manner as that described for $4 \mathbf{a}$ using $0.047 \mathrm{~g} \mathbf{2 f}$ and $0.031 \mathrm{~g}$ 1,2-bis(4methoxyphenyl)ethyne. $(0.043 \mathrm{~g}, 71.9 \%){ }^{1} \mathrm{H}$ NMR $d 7.01-6.97(\mathrm{~m}, 4 \mathrm{H}), 6.88-6.84(\mathrm{~m}, 4 \mathrm{H})$, $6.75(\mathrm{~d}, J=8.4 \mathrm{~Hz}, 2 \mathrm{H}), 6.70(\mathrm{~d}, J=8.2 \mathrm{~Hz}, 2 \mathrm{H}), 6.69-6.63(\mathrm{~m}, 8 \mathrm{H}), 6.41-6.37(\mathrm{~m}, 4 \mathrm{H}), 4.62$ $(\mathrm{s}, 2 \mathrm{H}), 4.26(\mathrm{~s}, 2 \mathrm{H}), 3.61(\mathrm{~s}, 6 \mathrm{H}), 3.20(\mathrm{~s}, 3 \mathrm{H}), 1.12-1.04(\mathrm{~m}, 3 \mathrm{H}), 1.01(\mathrm{~d}, J=6.7 \mathrm{~Hz}, 18 \mathrm{H}) ;{ }^{13} \mathrm{C}$ NMR $(318 \mathrm{~K}) d 157.02,157.00,140.84,140.73,140.69,140.30,139.85,139.54,139.49,138.76$, 138.67, 138.64, 138.61, 134.90, 132.94, 132.91, 132.77, 132.75, 132.38, 132.25, 131.29, 130.99, 129.98, 129.96, 126.42, 124.27, 119.60, 119.56, 112.23, 74.29, 64.74, 57.38, 54.87, 54.84, 36.61, 17.96, 11.98; FAB HRMS Calc. for $\mathrm{C}_{56} \mathrm{H}_{58} \mathrm{LiBr}_{2} \mathrm{O}_{4} \mathrm{Si}\left({ }^{+} \mathrm{M}+\mathrm{Li}\right)$ : 987.2631, Found: 987.2635.

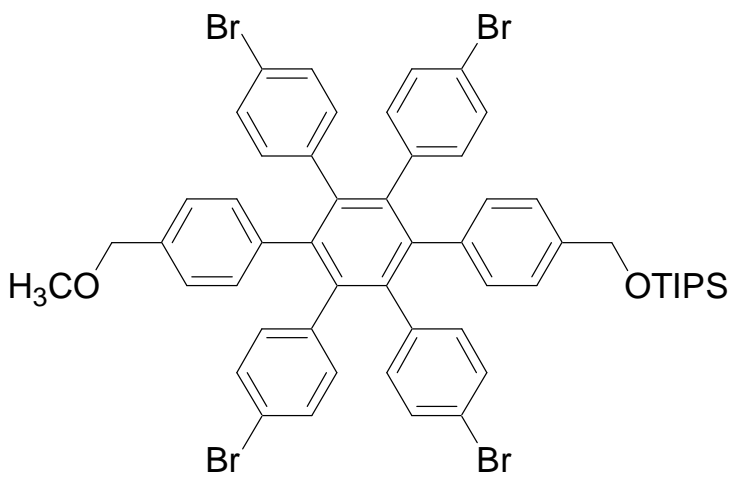

1-(4-(triisopropyl)siloxymethylphenyl)-4-(4-methoxymethylphenyl)-2,3,5,6-tetrakis-(4-

bromophenyl)benzene (4d) The tetraarylbenzene was prepared in the same manner as that described for $\mathbf{4 a}$ using $0.044 \mathrm{~g} \mathbf{2 f}$ and $0.024 \mathrm{~g}$ 1,2-bis(4-bromophenyl)ethyne. (0.038 g, $62.3 \%$ ) ${ }^{1} \mathrm{H} \mathrm{NMR} d 7.01(\mathrm{~d}, J=8.0 \mathrm{~Hz}, 4 \mathrm{H}), 6.99(\mathrm{~d}, J=8.0 \mathrm{~Hz}, 4 \mathrm{H}), 6.90-6.87(\mathrm{~m}, 4 \mathrm{H}), 6.73(\mathrm{~d}, J=$ $8.0 \mathrm{~Hz}, 2 \mathrm{H}), 6.68(\mathrm{~d}, J=8.2 \mathrm{~Hz}, 2 \mathrm{H}), 6.65(\mathrm{~d}, J=8.4 \mathrm{~Hz}, 4 \mathrm{H}), 6.63(\mathrm{~d}, J=8.4 \mathrm{~Hz}, 4 \mathrm{H}), 4.63(\mathrm{~s}$, $2 \mathrm{H}), 4.28(\mathrm{~s}, 2 \mathrm{H}), 3.21(\mathrm{~s}, 3 \mathrm{H}),\left(1.12-1.04(\mathrm{~m}, 3 \mathrm{H}), 1.01(\mathrm{~d}, J=6.7 \mathrm{~Hz}, 18 \mathrm{H}) ;{ }^{13} \mathrm{C} \mathrm{NMR}(318 \mathrm{~K}) d\right.$ $140.59,140.17,139.49,139.36,138.96,138.93,135.51,132.74,132.71,131.07,130.80,130.09$, $129.68,126.56,125.94,124.53,123.17,119.89,119.85,118.85,64.65,57.41,36.61,18.03$, 11.96; IR (neat): 2921.40, 2852.02, 1491.39, 1462.20, 1388.67, 1139.62, 1093.63, 1070.62, 1010.38, 882.07, 862.53, 826.67, 765.04, 683.96; MALDI-MS Calc. for $\mathrm{C}_{56} \mathrm{H}_{58} \mathrm{LiBr}_{2} \mathrm{O}_{4} \mathrm{Si}\left({ }^{+} \mathrm{M}-\right.$ $\mathrm{H}_{2}$ ): 987.2631, Found: 987.2635. 
(1) Liu, X.; Zheng, Q.-H.; Fei, X.; Wang, J.-Q.; Ohannesian, D. W.; Erickson, L. C.; Stone, K. L.; Hutchins, G. D. Bioorg. Med. Chem. Lett. 2003, 13, 641.

(2) White, A. W.; Almassy, R.; Calvert, A. H.; Curtin, N. J.; Griffin, R. J.; Hostomsky, Z.; Maegley, K.; Newell, D. R.; Srinivasan, S.; Golding, B. T. J. Med. Chem. 2000; 43, 4084.

(3) Takeuchi, K.; Kohn, T. J.; Mais, D. E.; True, T. A.; Wyss, V. L.; Jakubowski, J. A. Bioorg. Med. Chem. Lett. 1998, 8, 1943.

(4) Cumming, J. N.; Wang, D.; Park, S. B.; Shapiro, T. A.; Posner, G. H. J. Med. Chem. 1998, $41,952$.

(5) Winter, S. R. Ph.D. dissertation, Stanford University, Stanford, CA, 1973; Komoto, R.G.

Ph.D. disertation, Stanford University, Stanford, CA, 1974.

(6) Laidler, K. J. Chemical Kinetics; McGraw-Hill: New York, 1950; p 10.

(7) L'Esperance, R. P.; Engen, D. V.; Dayal, R.; Pascal, R. A. J. Org. Chem. 1991, 56, 688.

(8) Ito, S.; Wehmeier, M.; Brand, J. D.; Kuebel, C.; Epsch, R.; Rabe, J. P.; Muellen, K. Chem.

Europ. J. 2000, 6; 4327.

(9) Inaba, S.; Rieke, R. D. J. Org. Chem. 1985, 50, 1373.

(10) House, H. O.; Berkowitz, W. F. J. Org. Chem. 1963, 28, 2271.

${ }^{11}$ Coan, S. B.; Trucker, D. E.; Beckerr, E. I. J. Am. Chem. Soc. 77; 1955, 77, 60. 


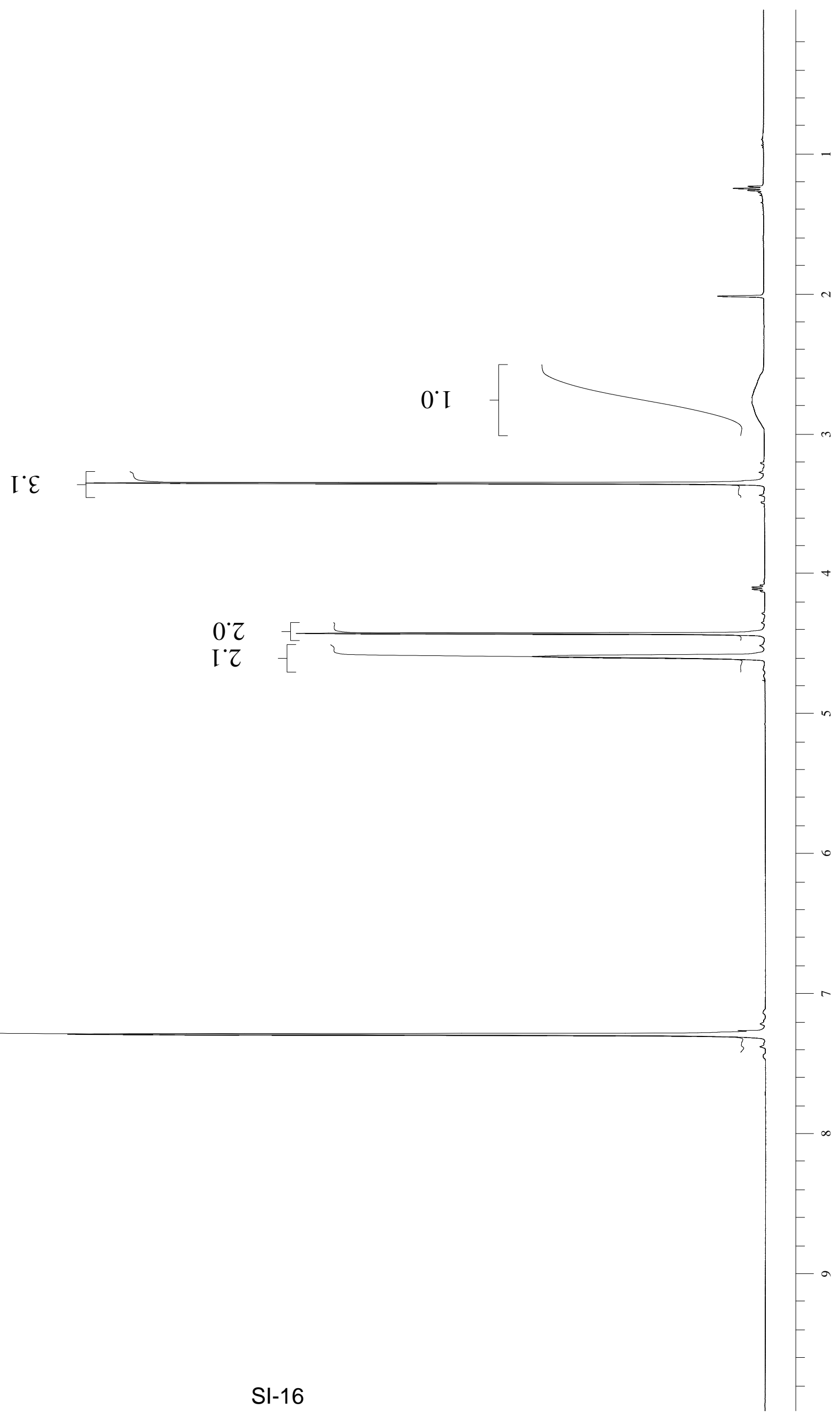




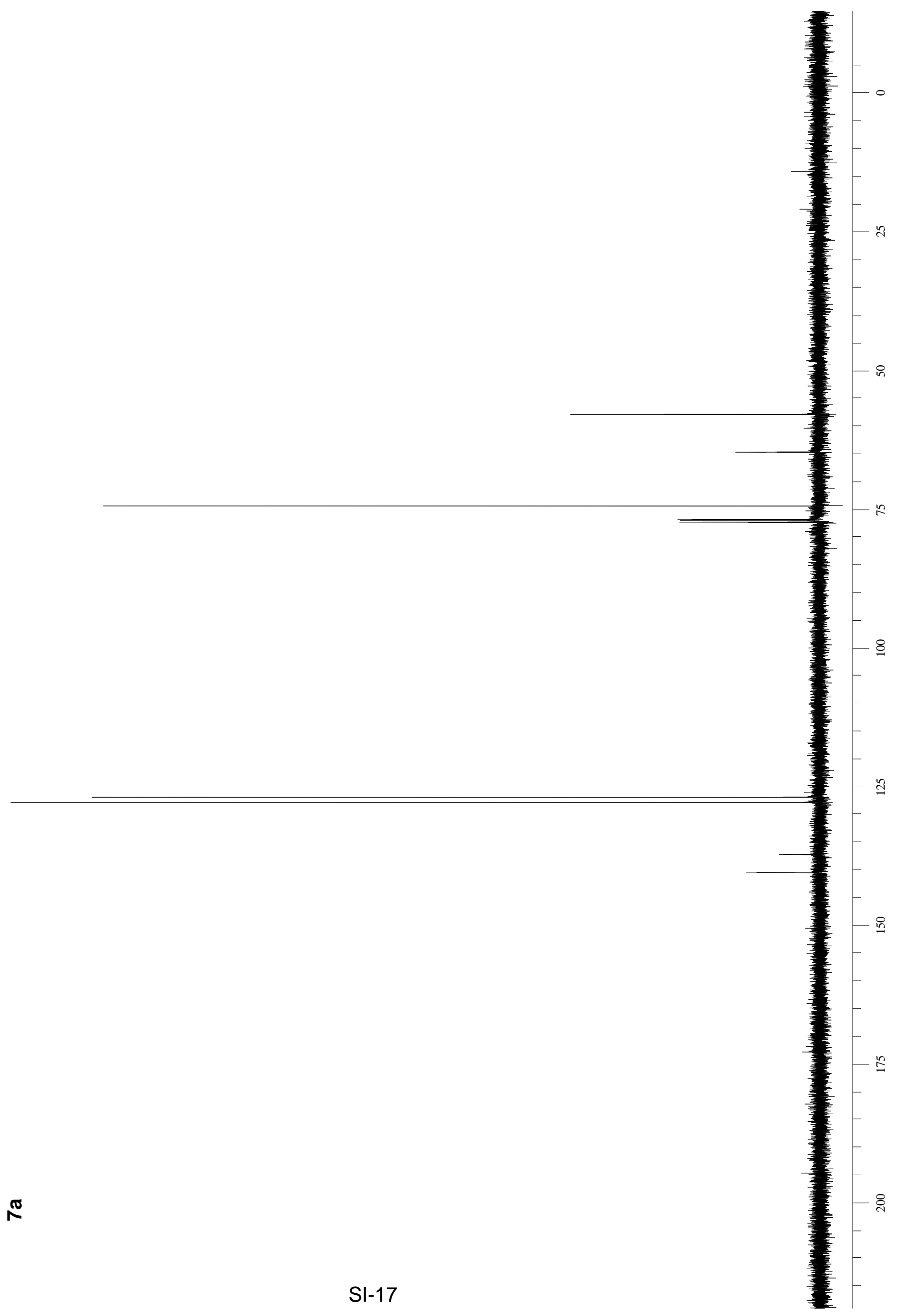


$\varsigma \cdot 6 \mathrm{I}$

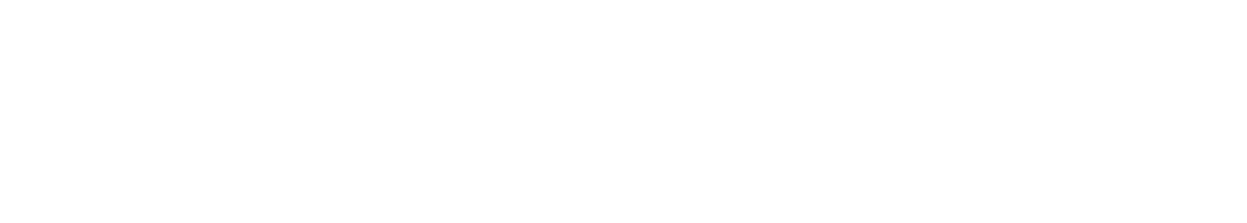

$-[$

$0 \cdot \tau$

I 2

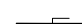

$\underbrace{0}_{\substack{1 \\ 0}}$

$z \dot{0} \bar{c}-\longleftarrow$ 


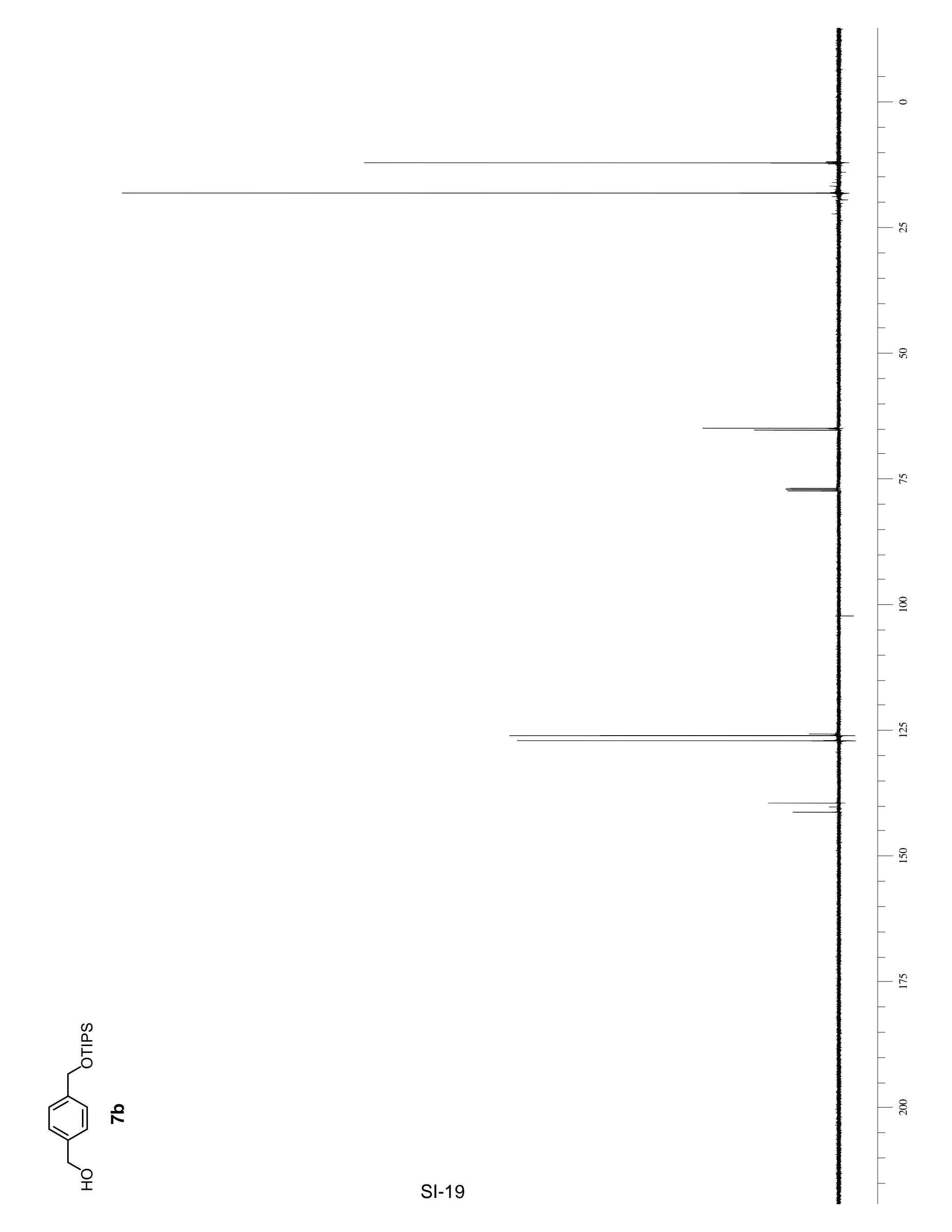




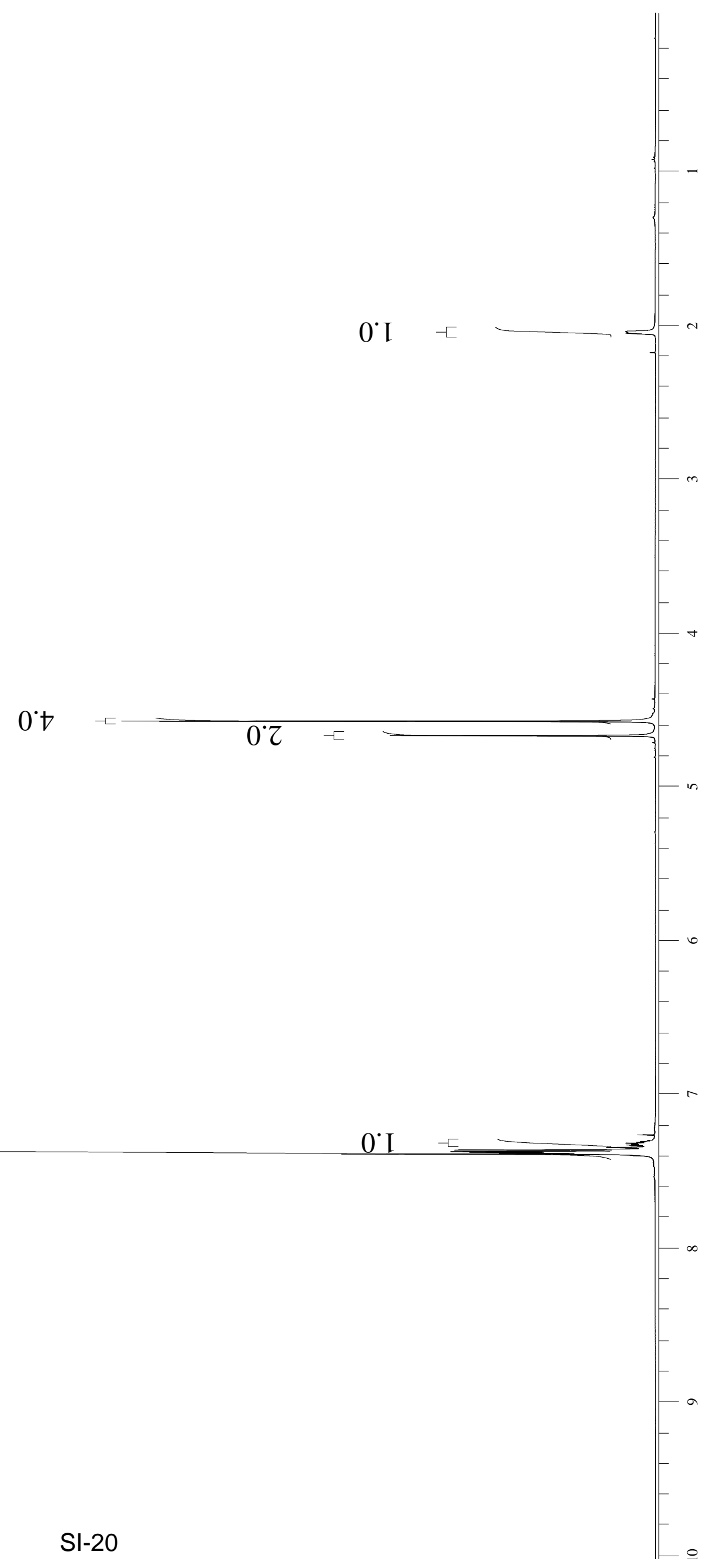




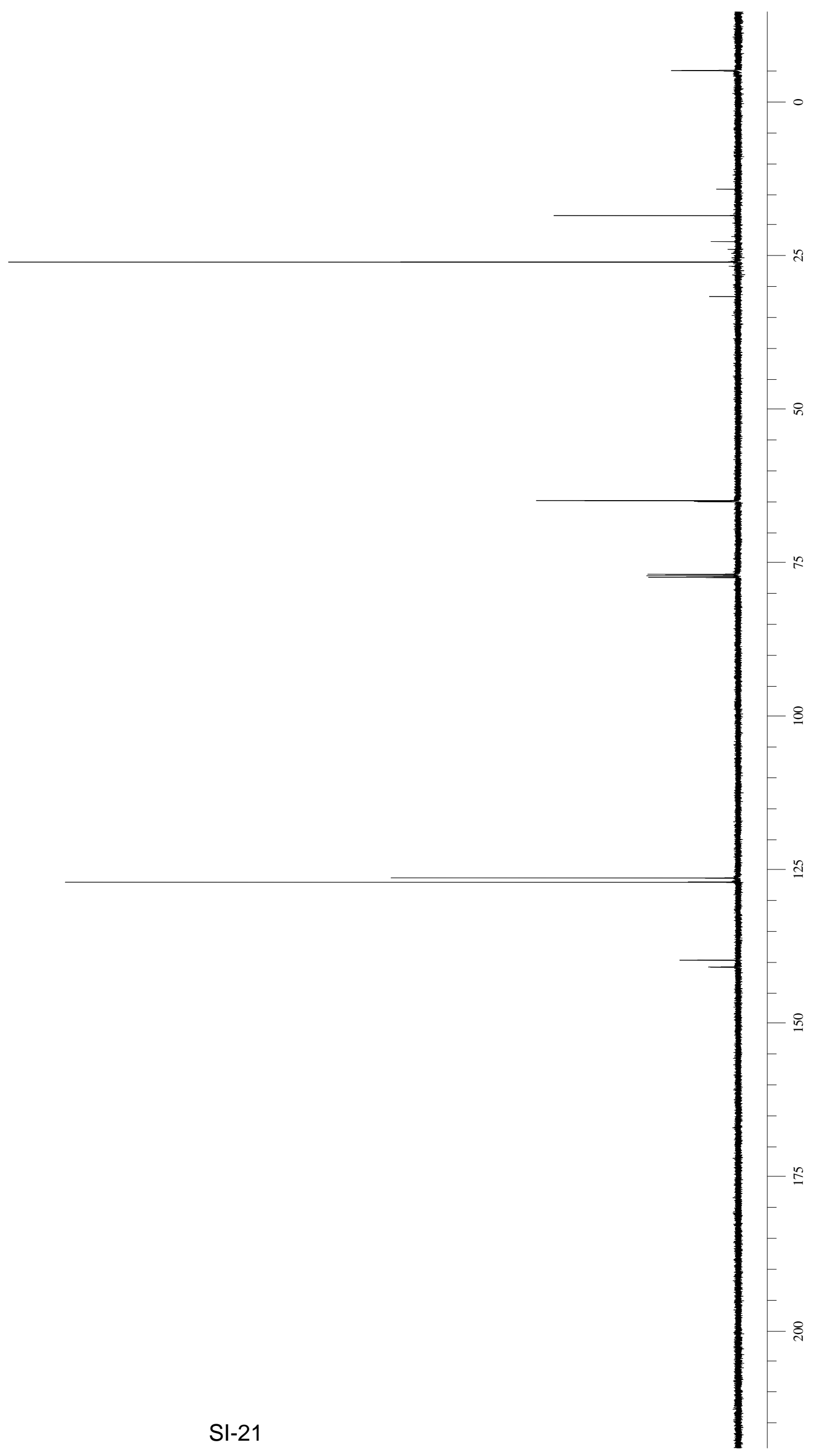


$6^{\circ} \mathrm{S}$

68

$0 \%$

I $r$

0

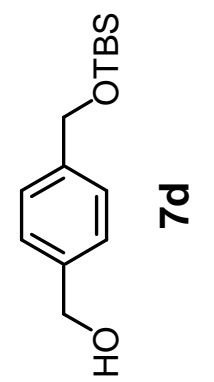

SI-22 


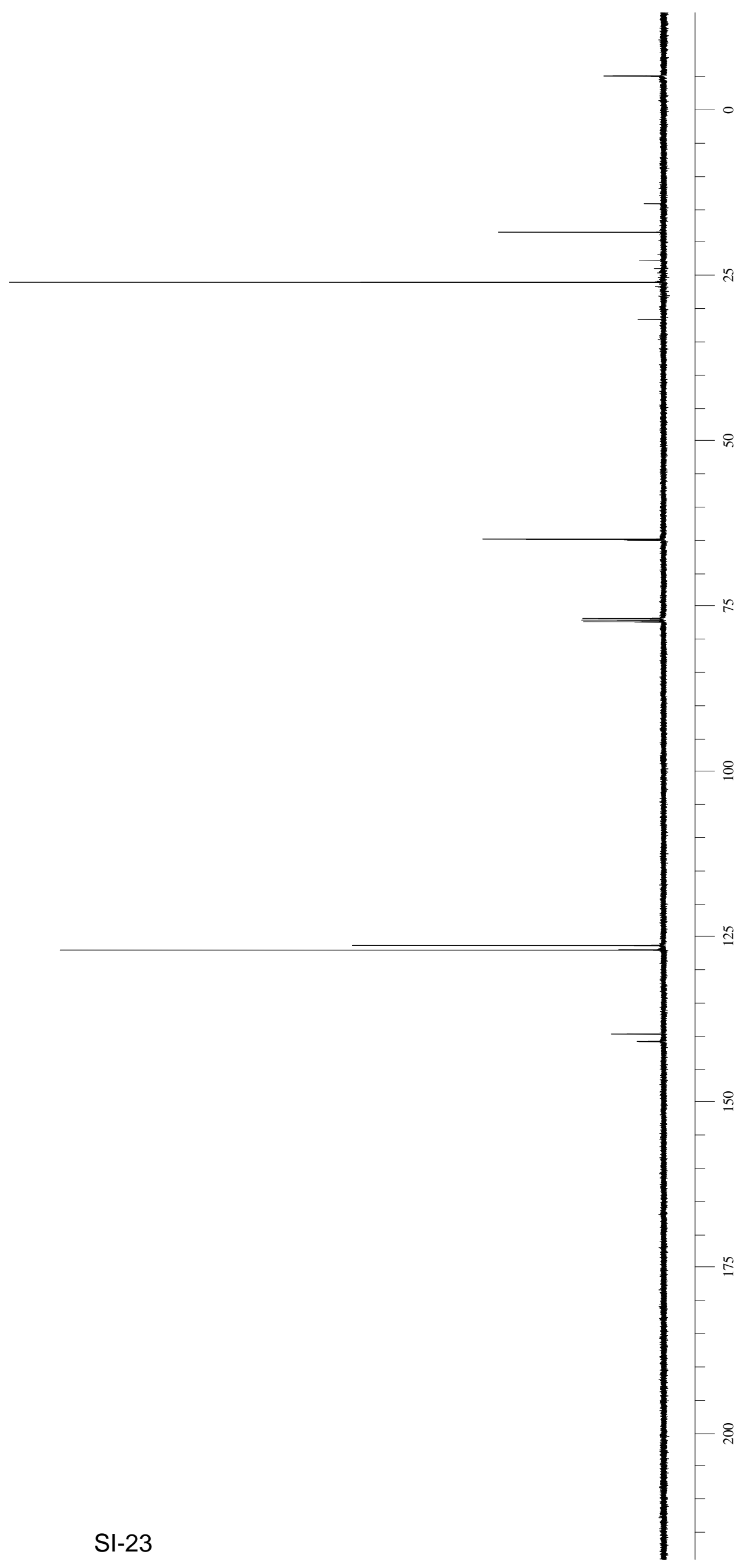




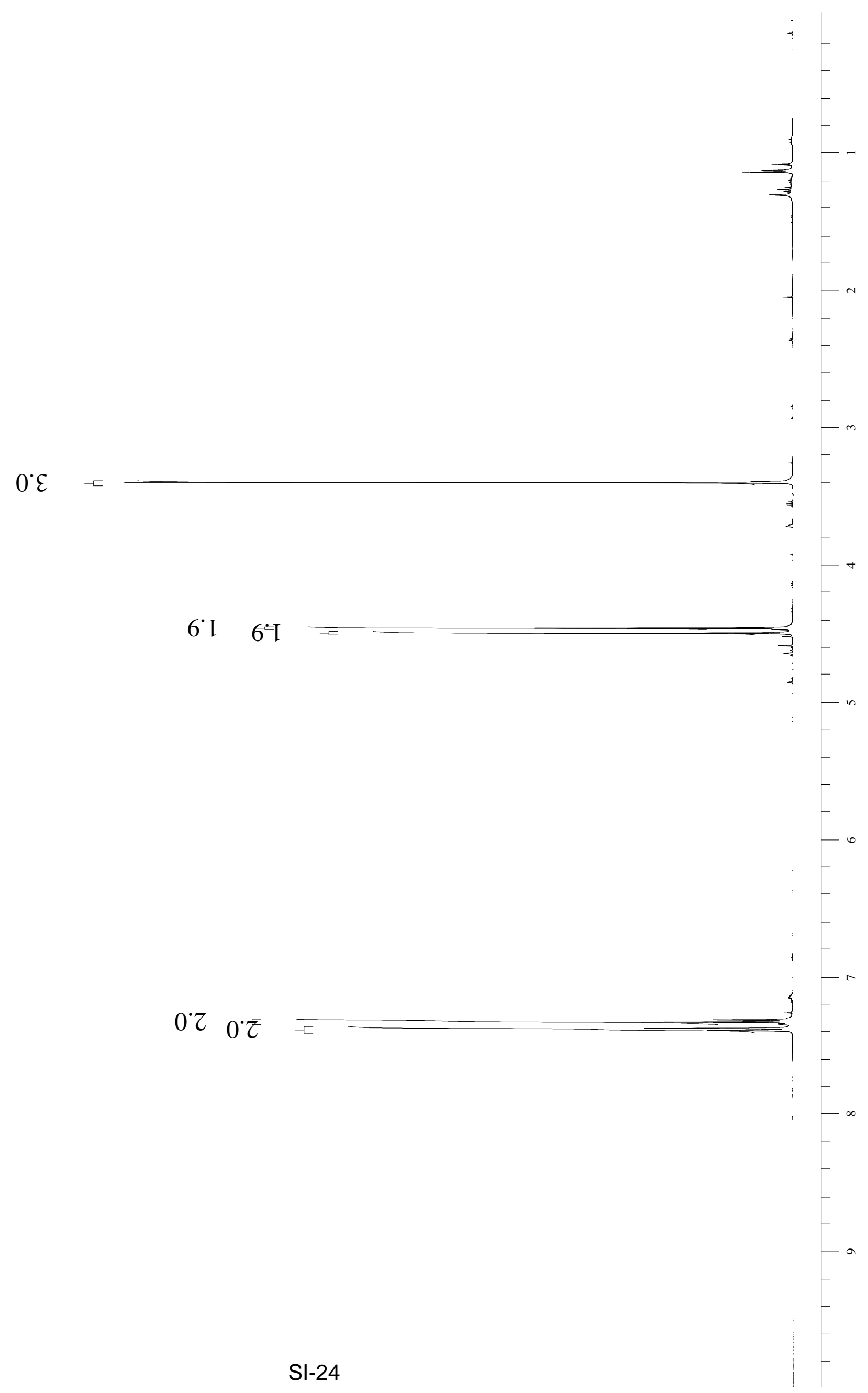



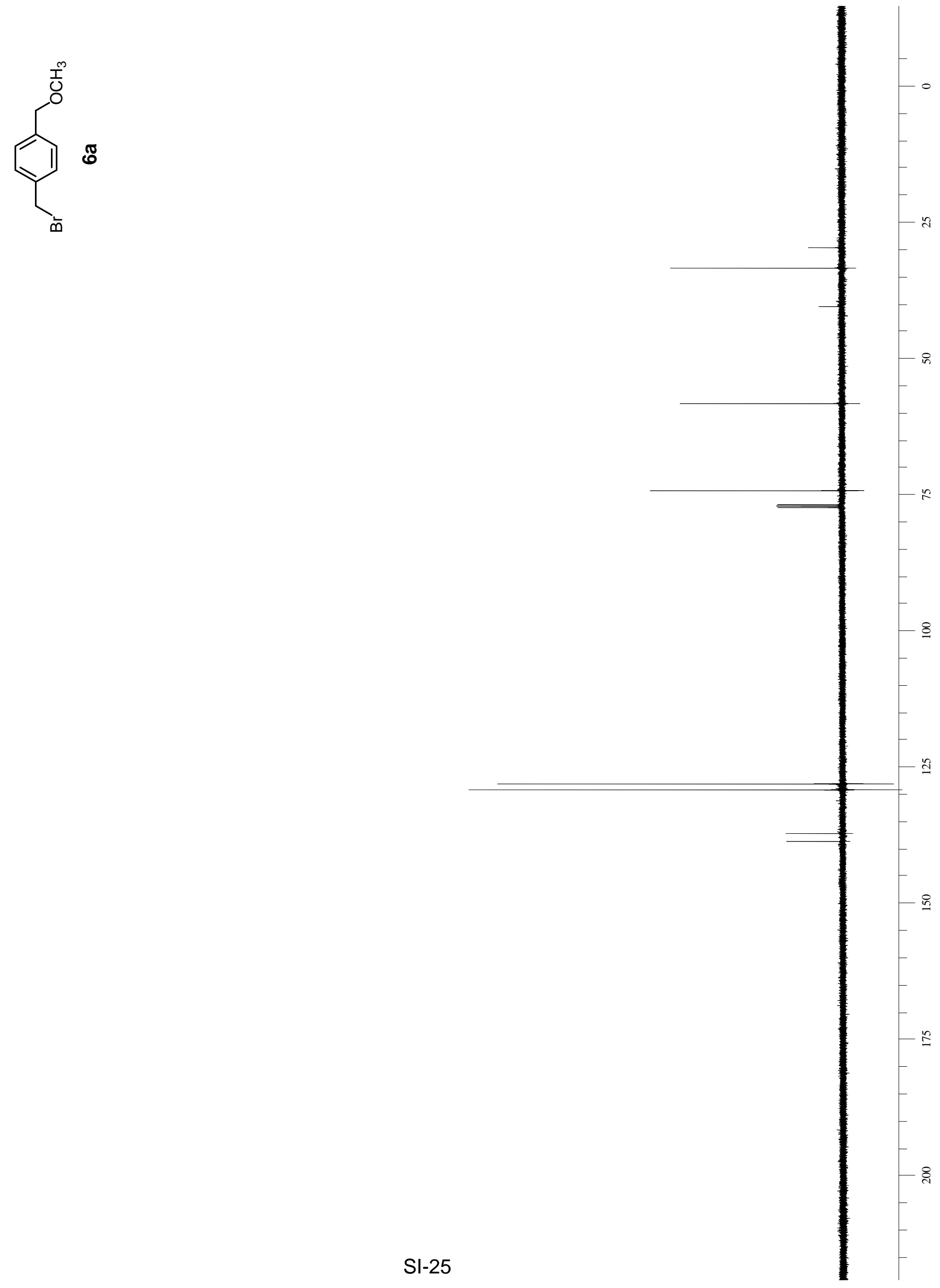
2*6I

$t^{\circ} \mathcal{E}$

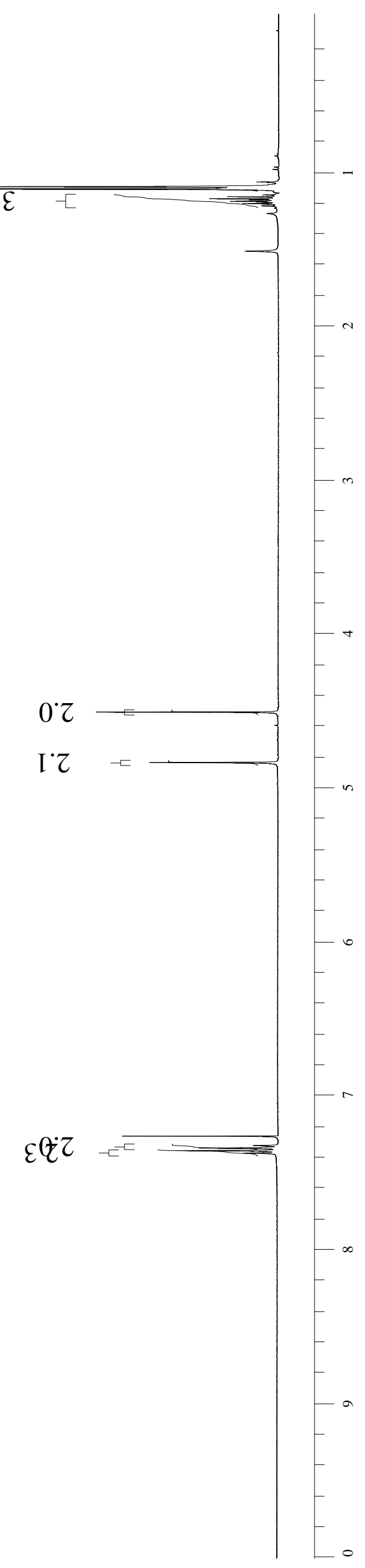



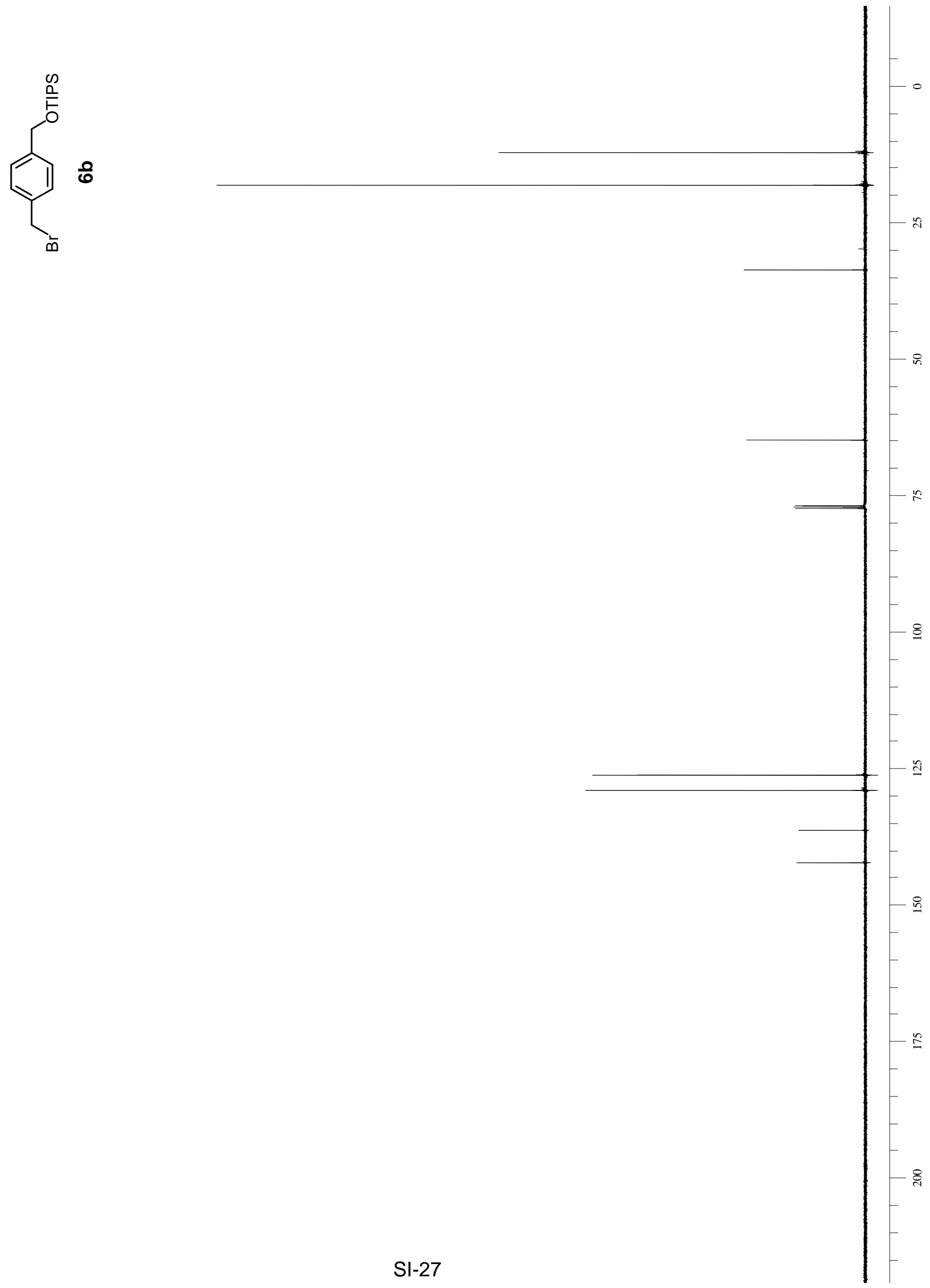


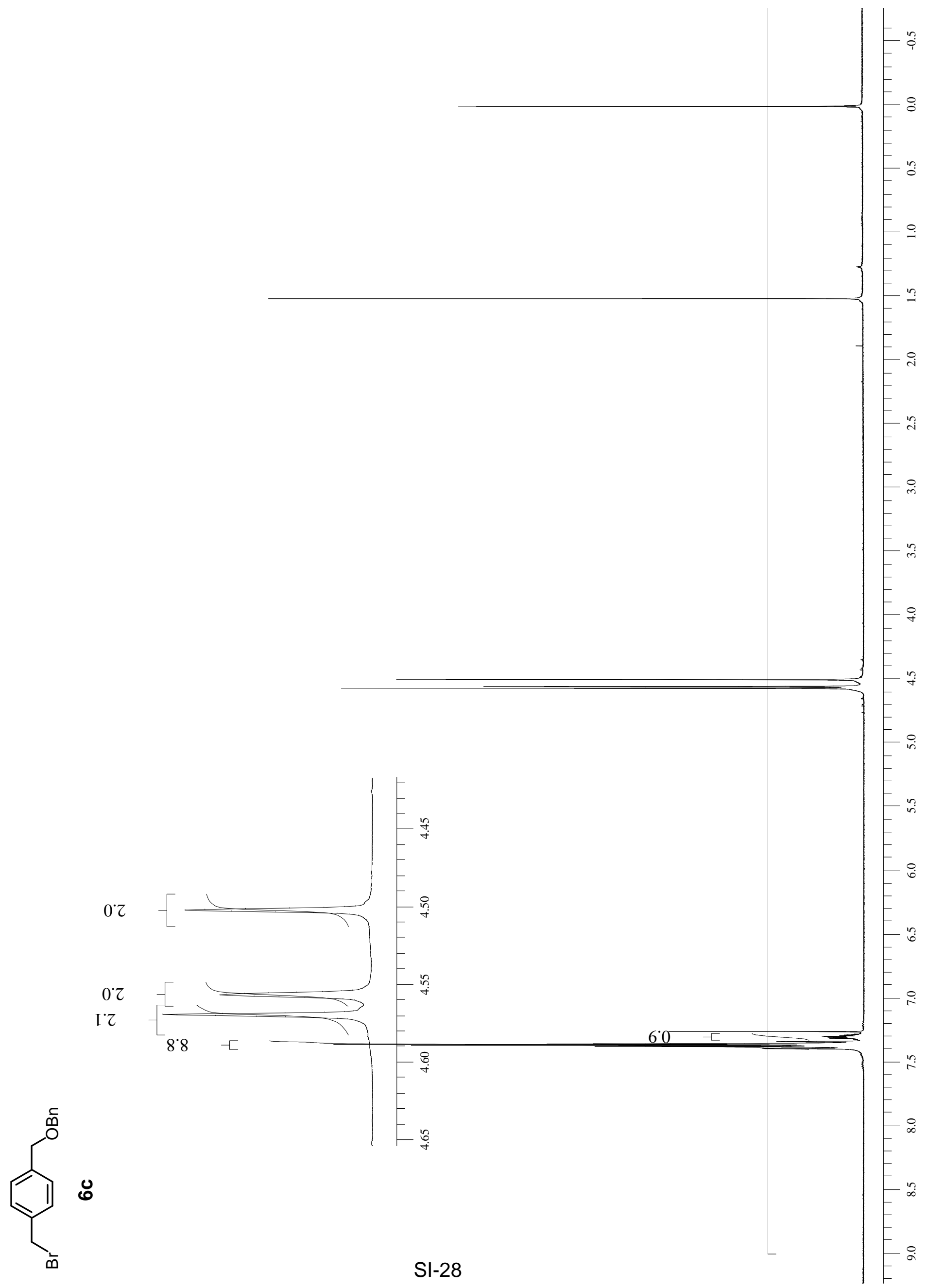



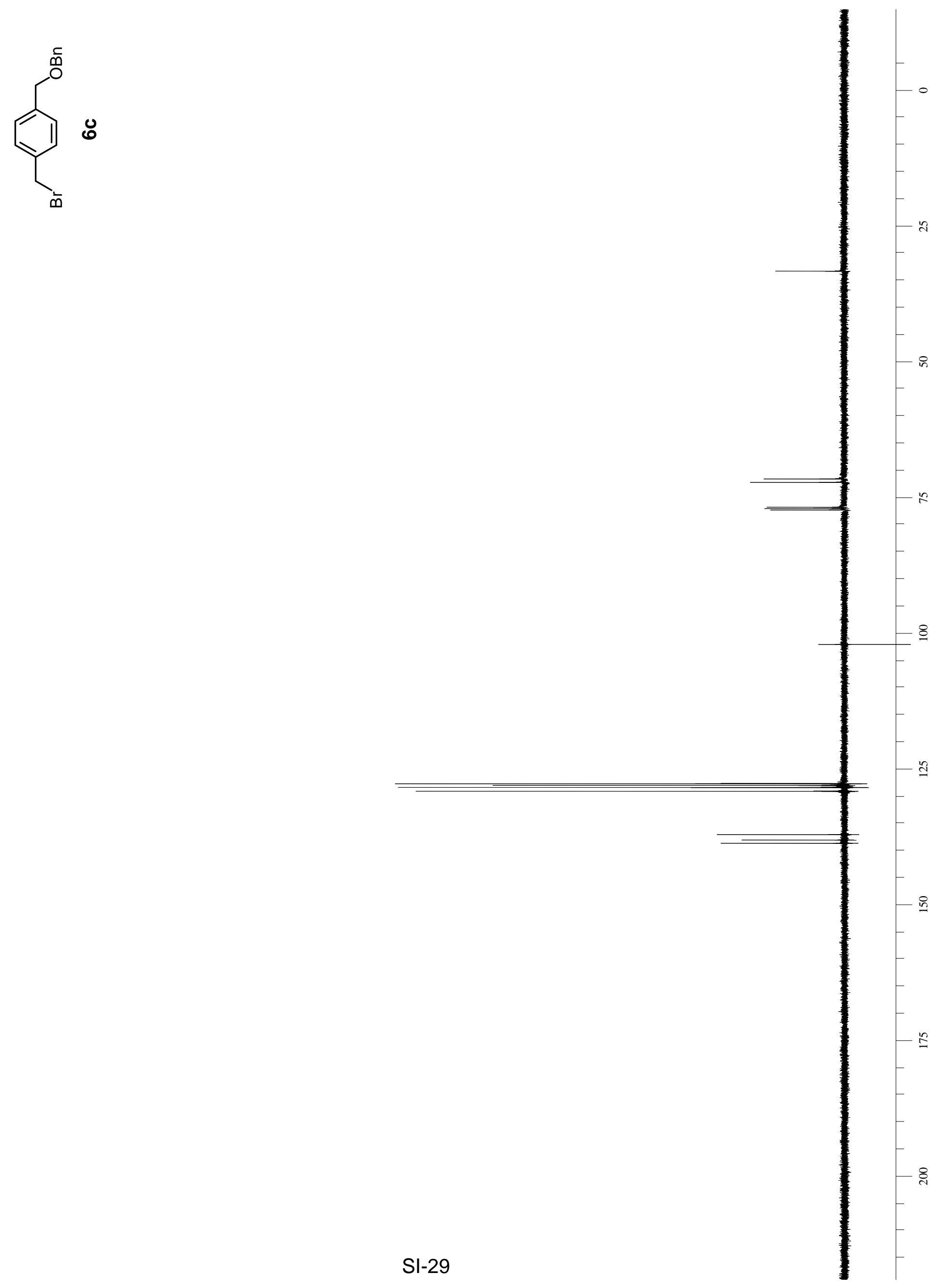
$6^{\circ} \mathrm{S}$

I.6 -

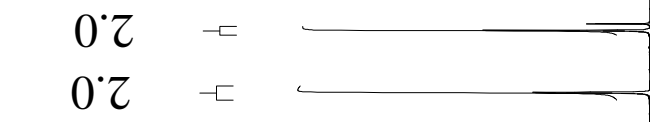

$\nabla^{\circ} 6^{\circ}$

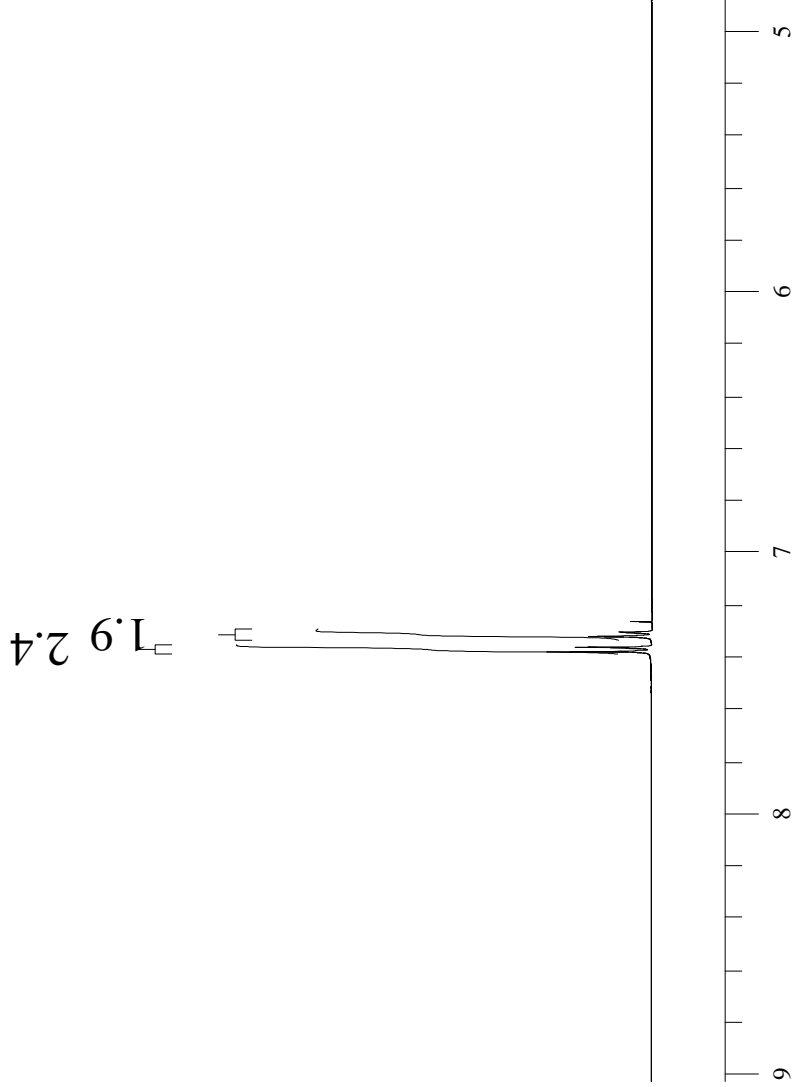



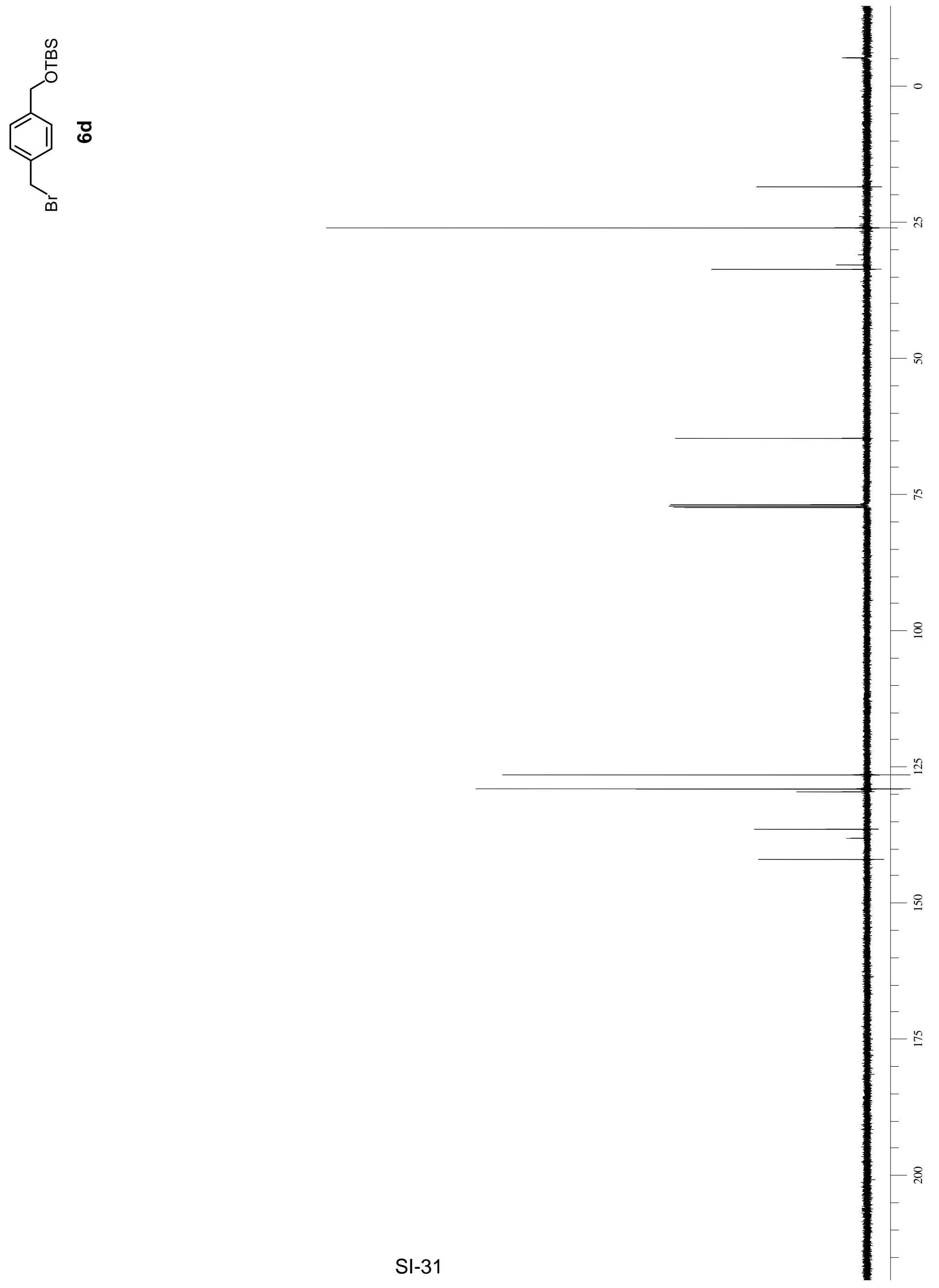


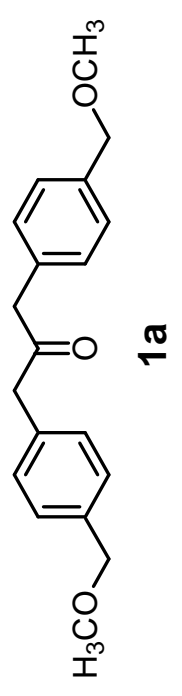

$\varepsilon^{\cdot} \mathcal{E}$

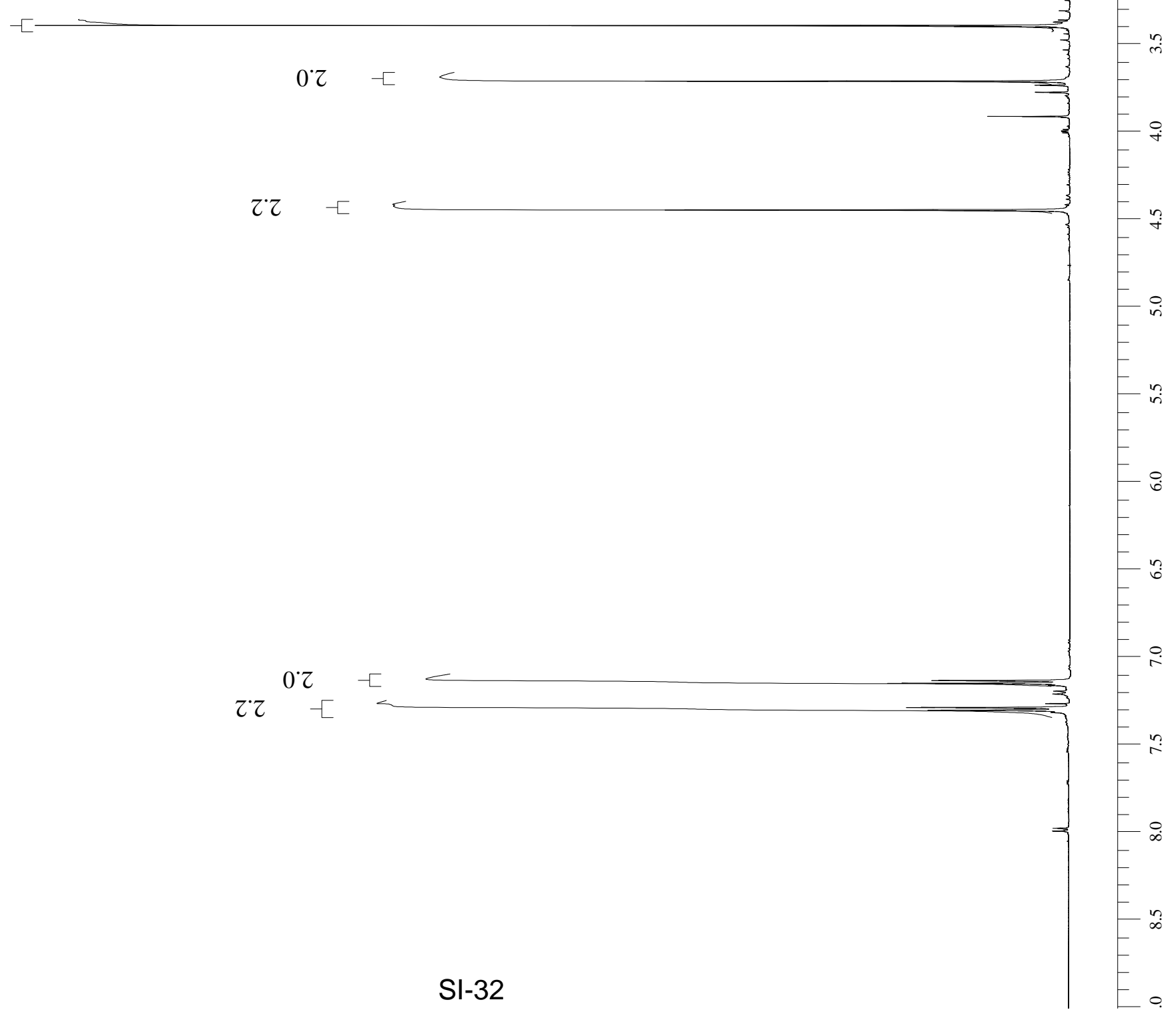



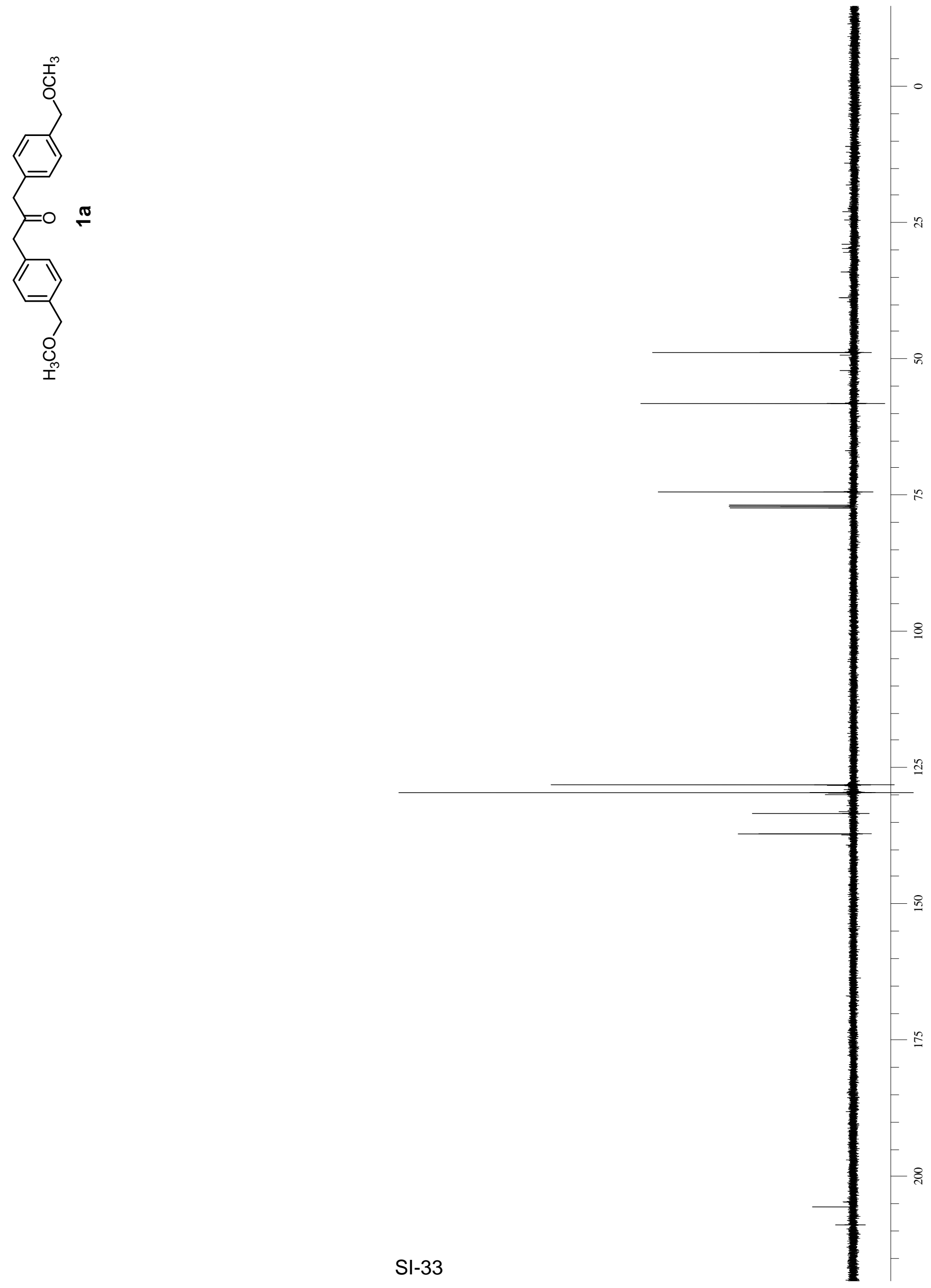


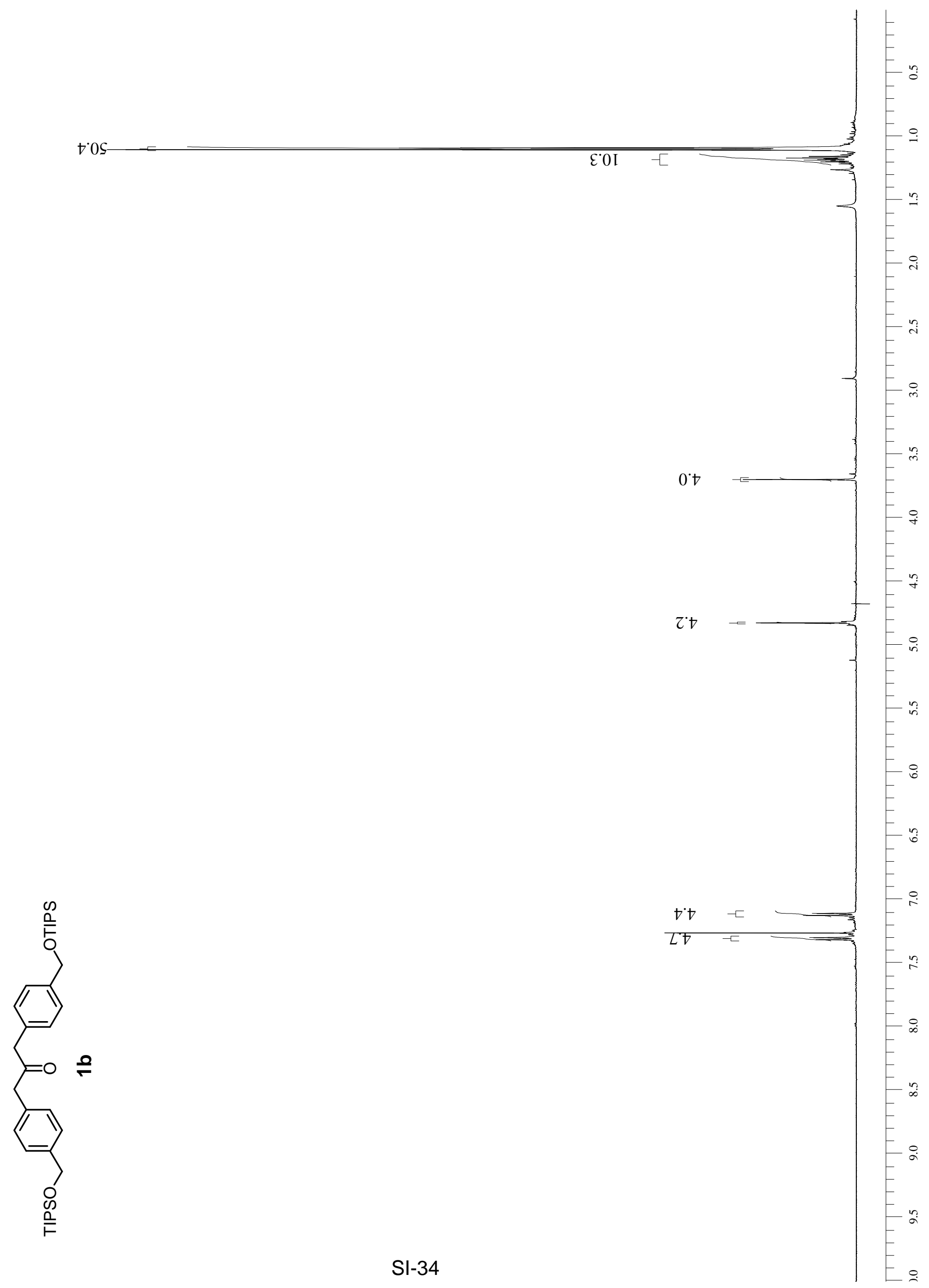



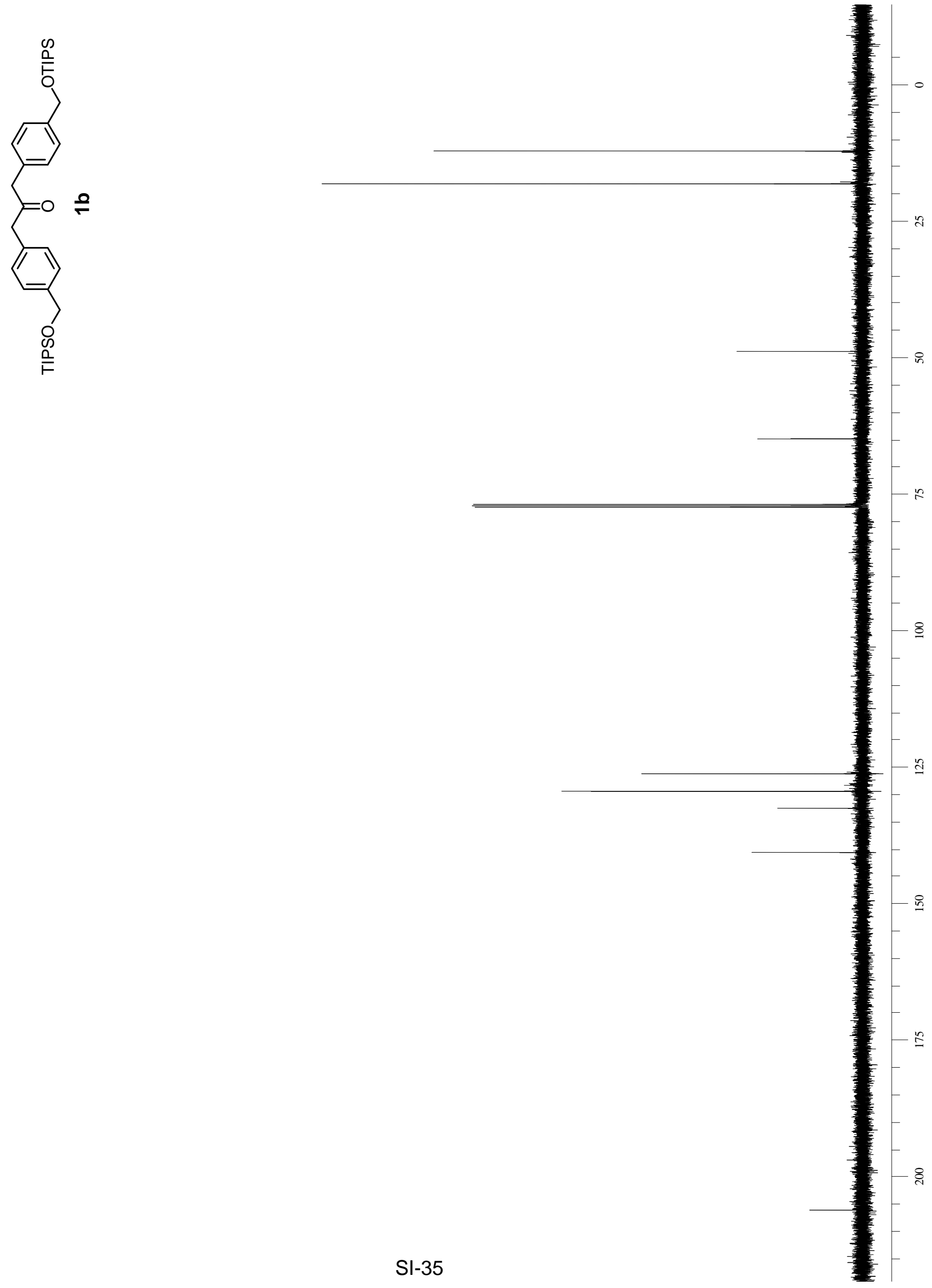


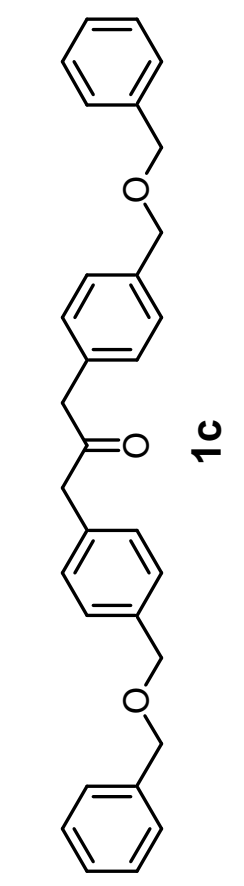

$6 \cdot \varepsilon I$

0.8

$0 \circ$

0

SI-36 


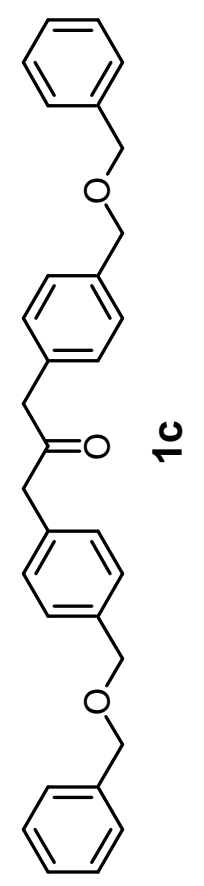


$0 \%$ I

$6 \cdot L I$

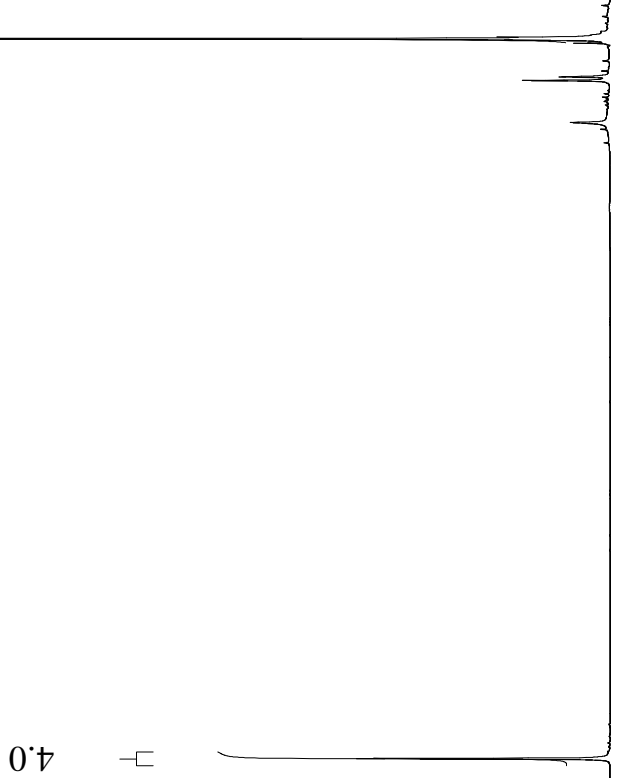

ס

0 เ

$6 \cdot \mathcal{\varepsilon}-\sqsubset$

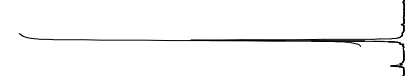




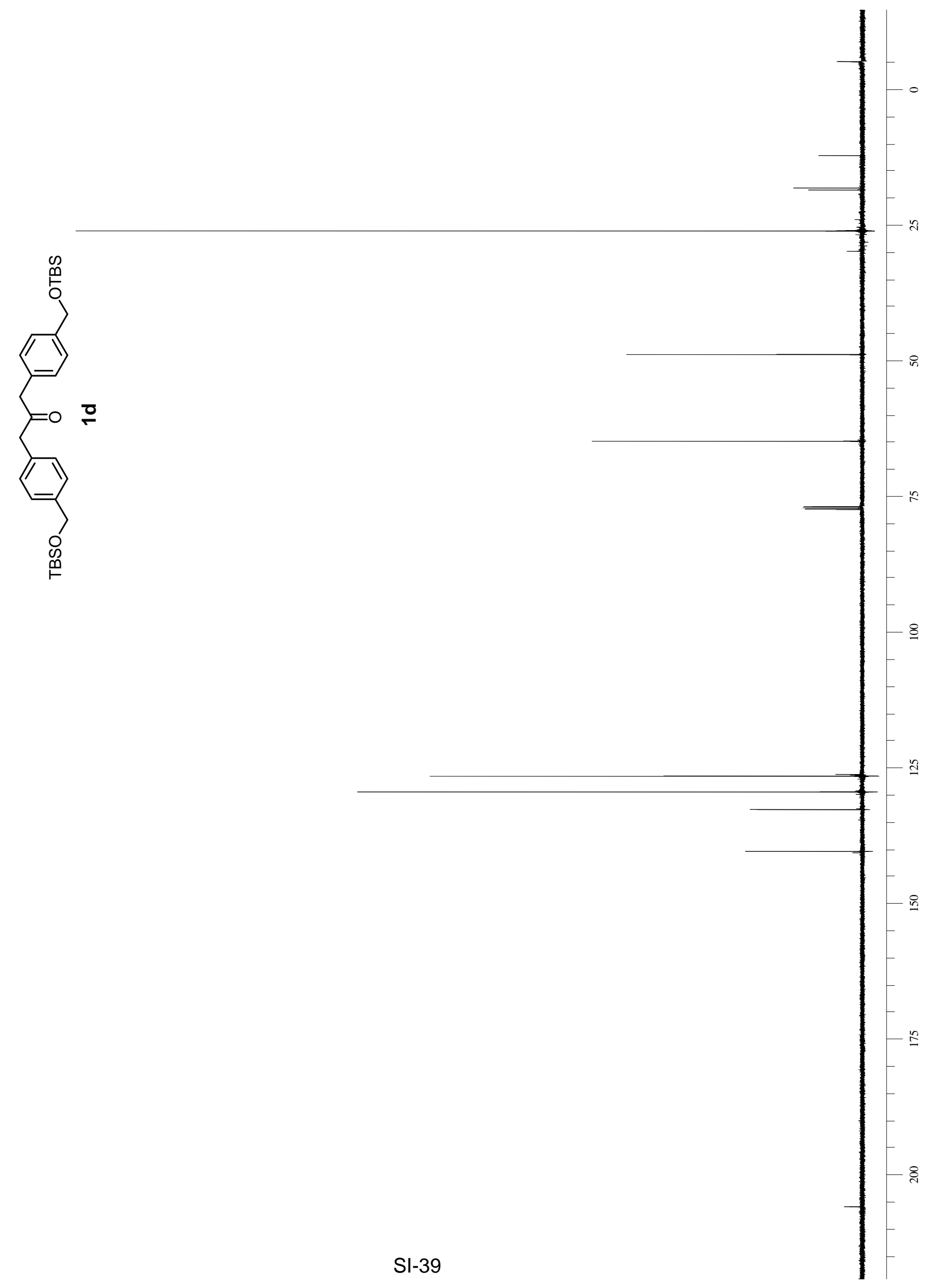




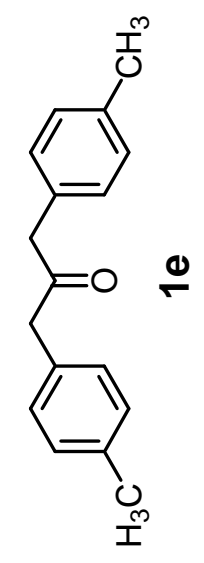

I 9

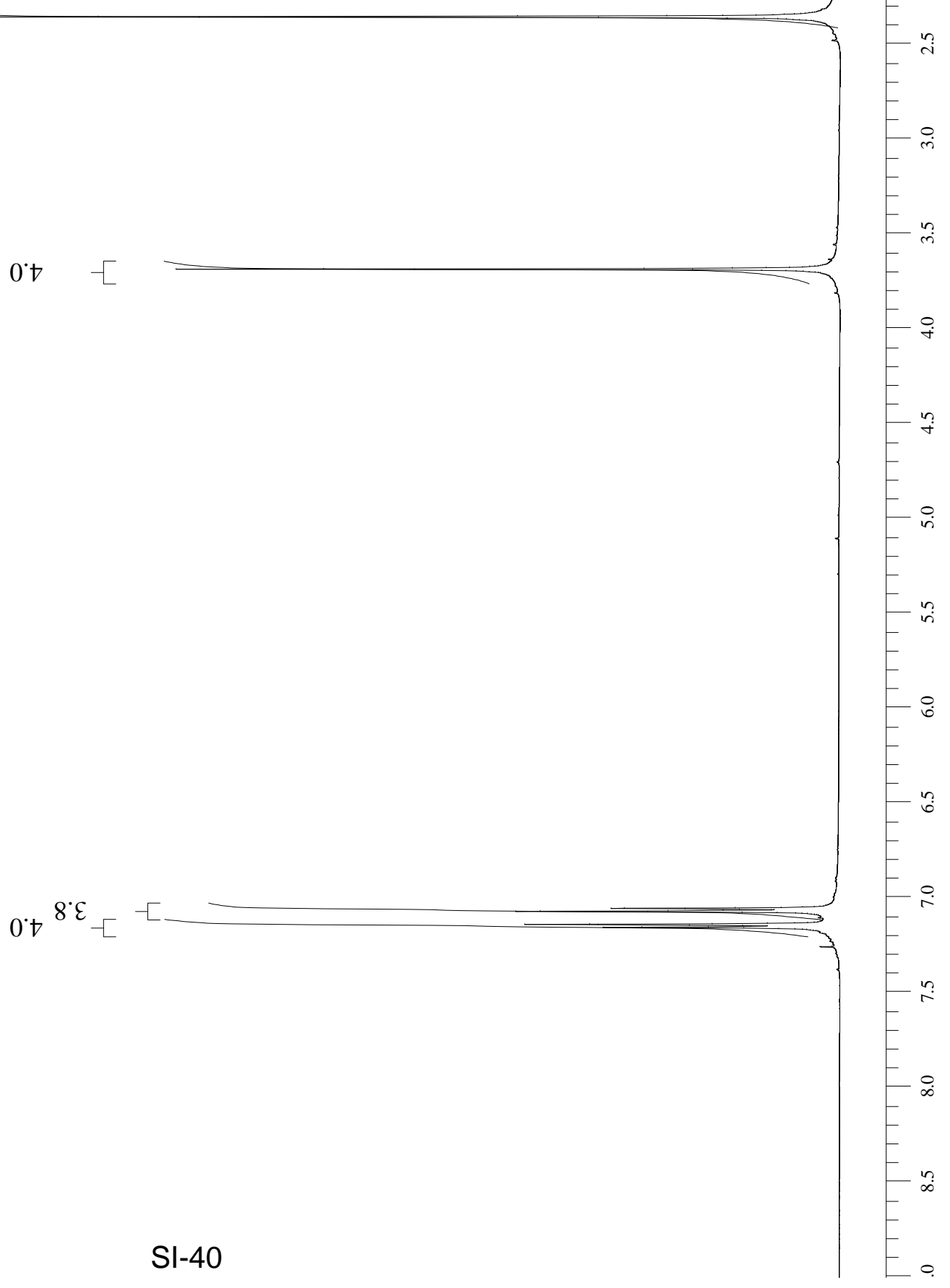



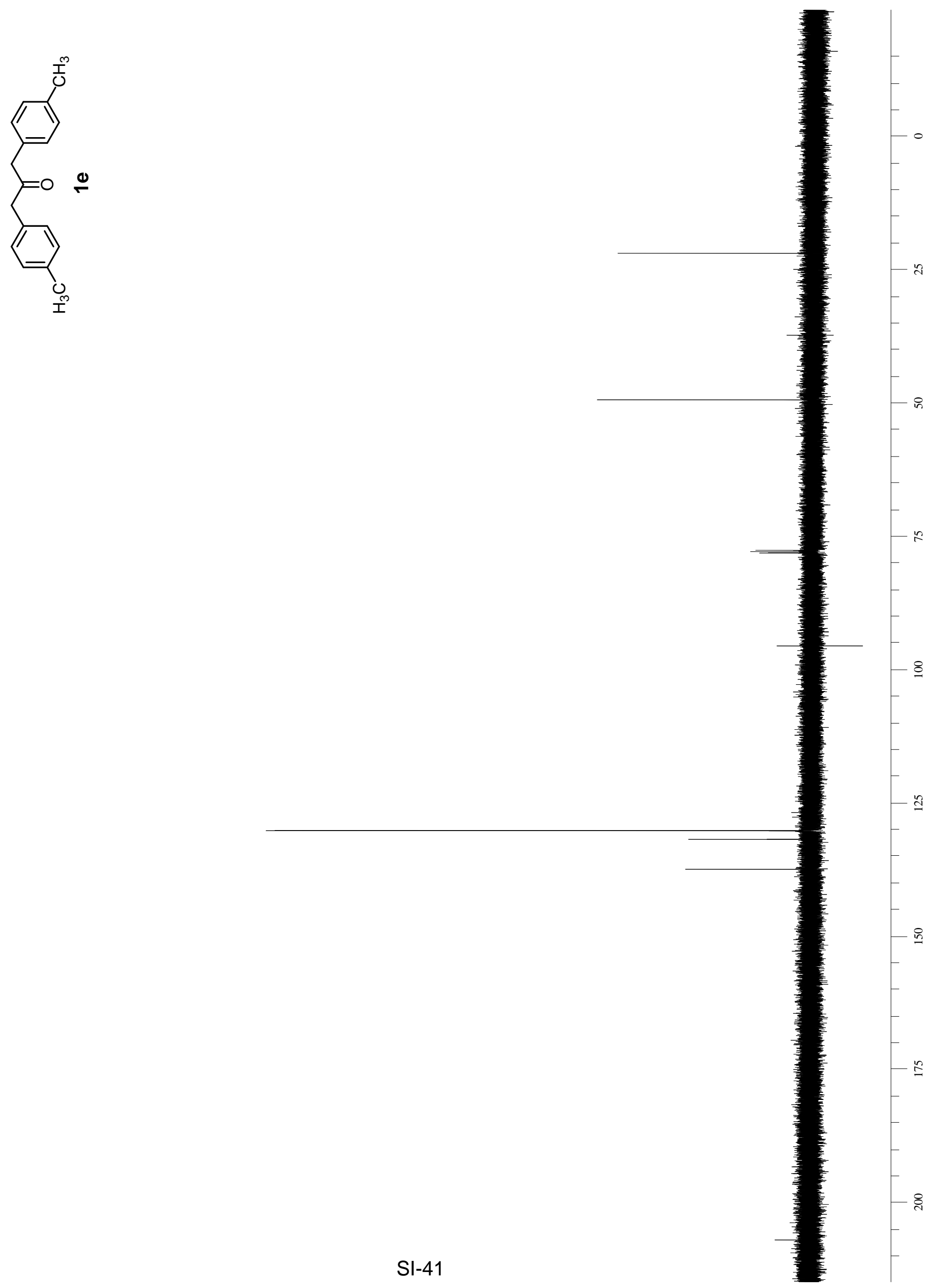

SI-41 


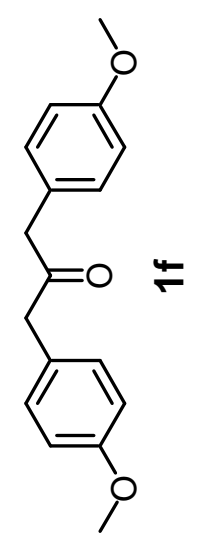

09

$I^{\circ} \nabla=$

$6^{\circ} \mathcal{E}-\sqsubset$

$8^{\circ} \mathcal{E}-\sqsubset$ 

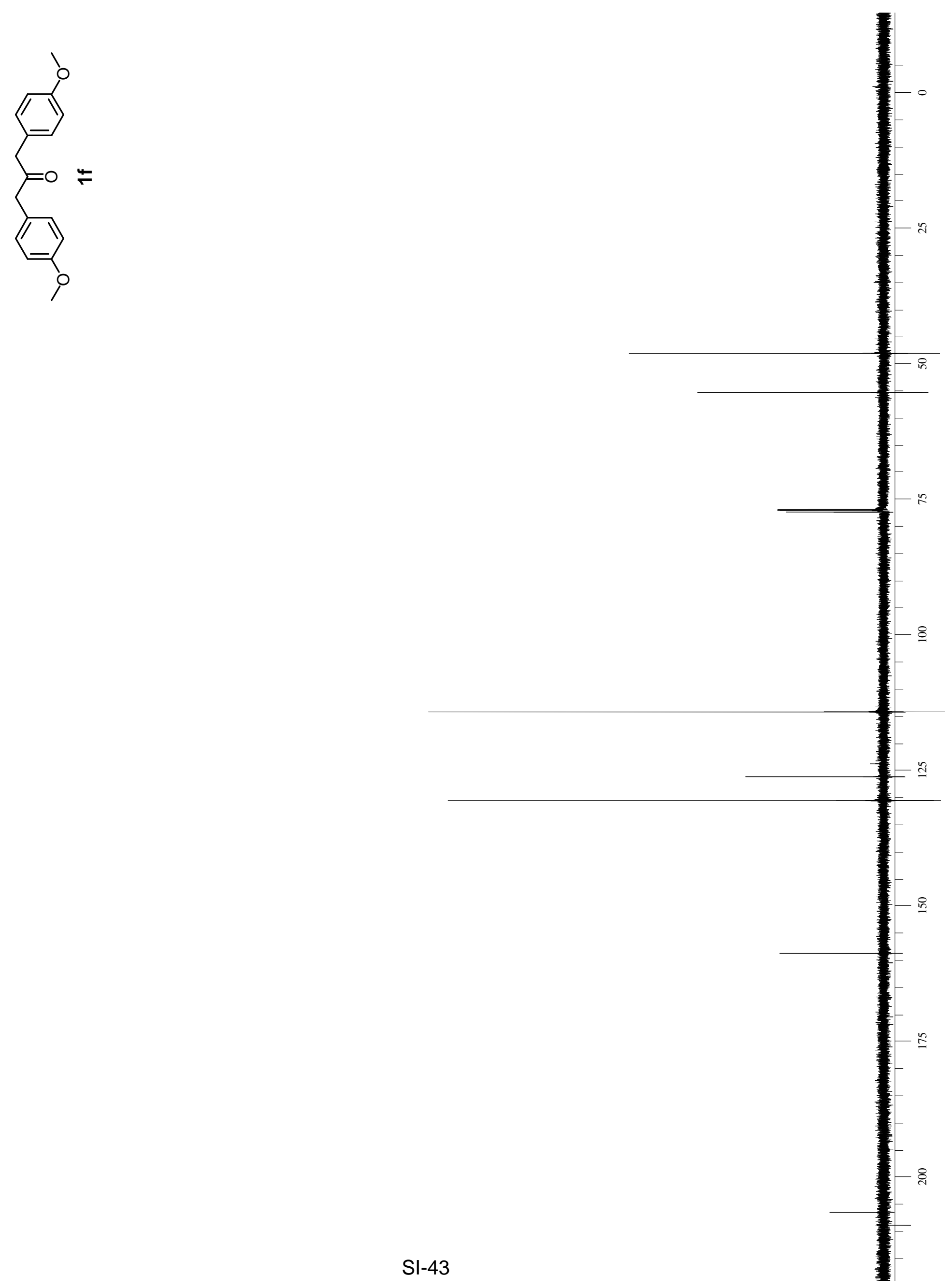

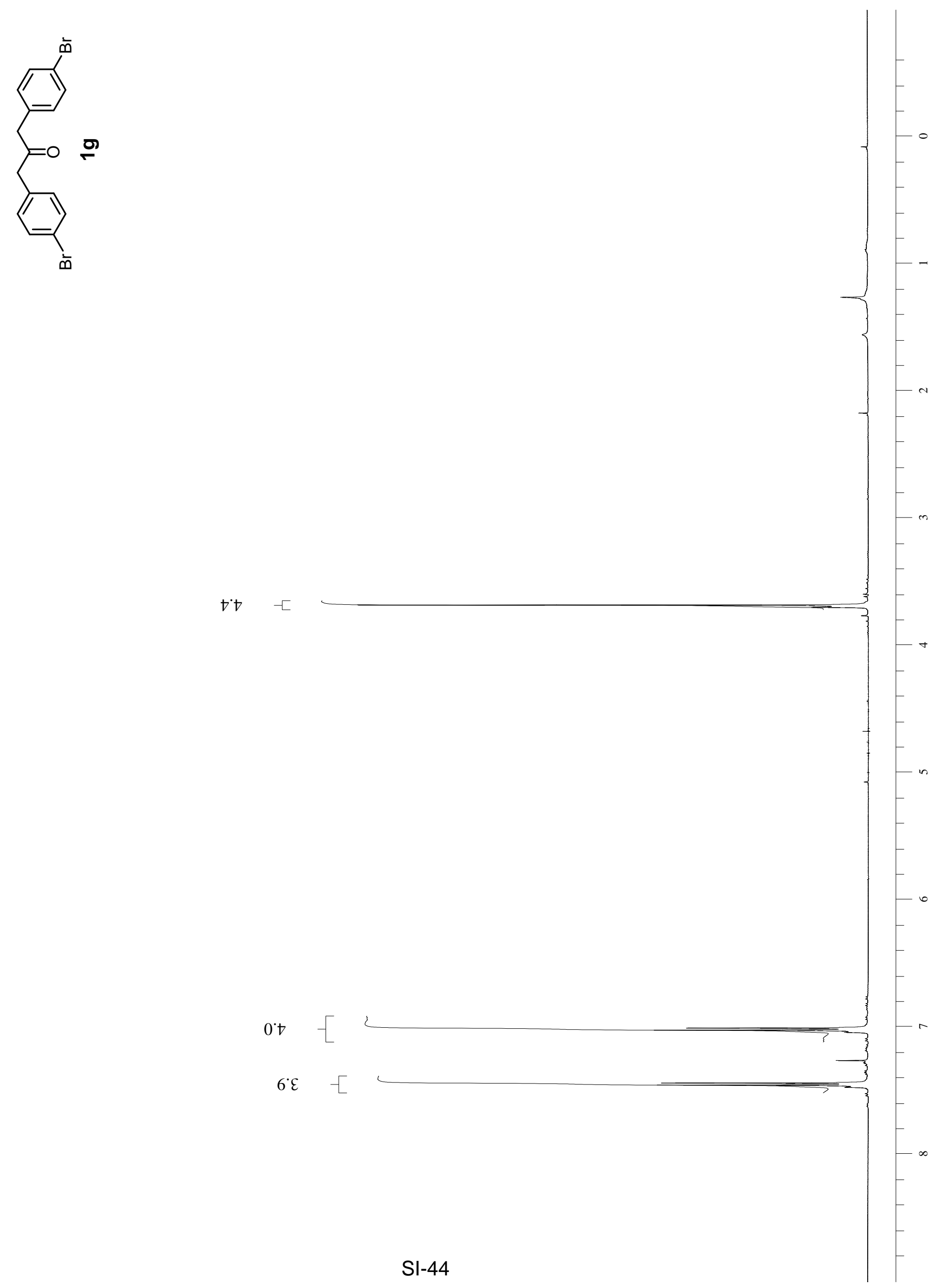

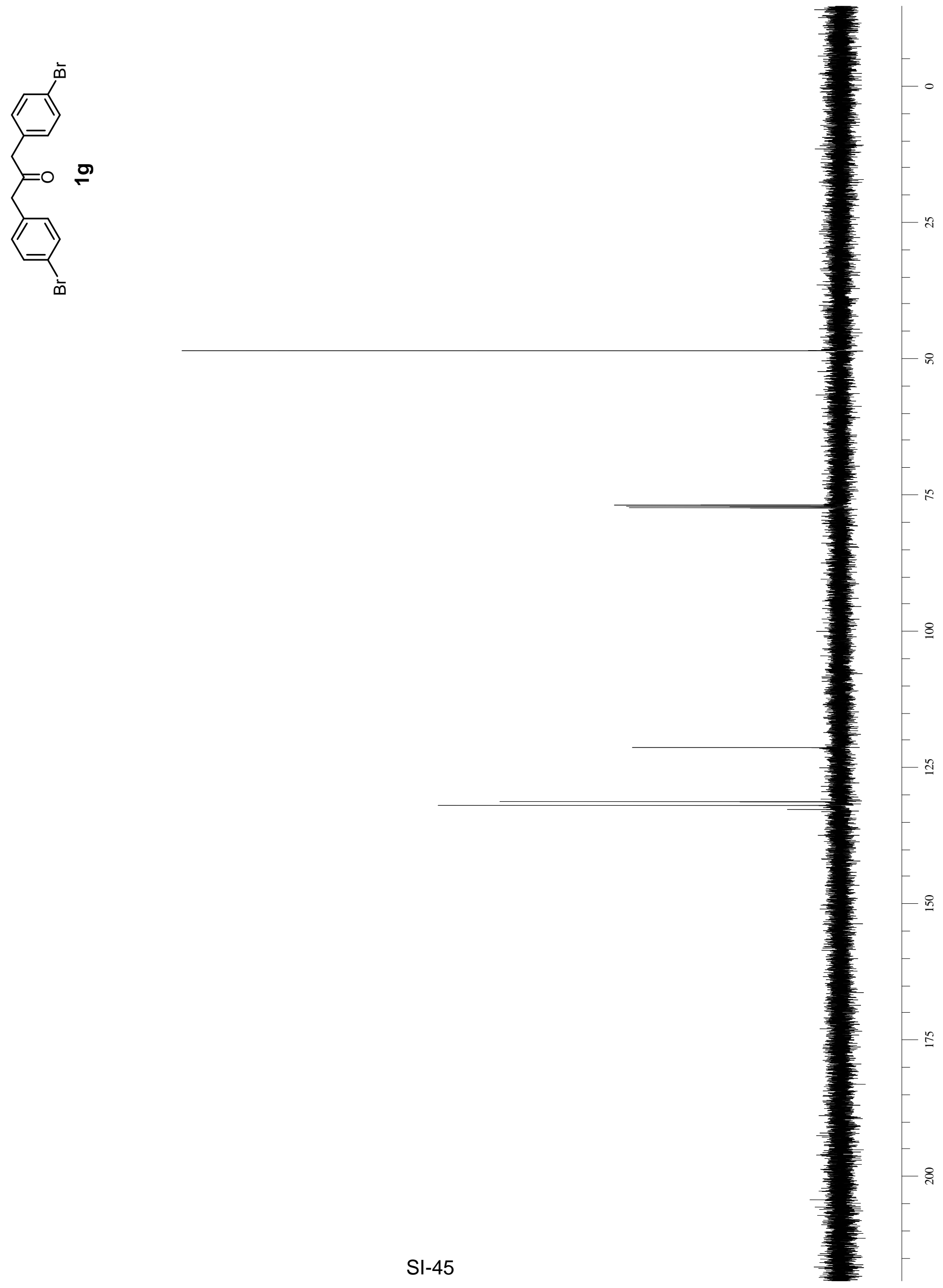


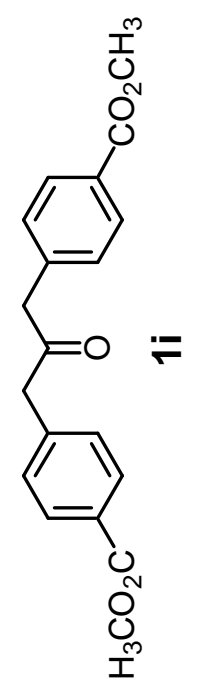




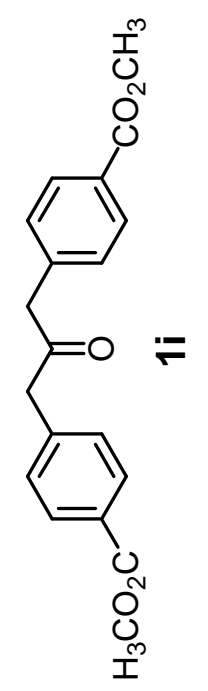


$\mathcal{E} 97 \quad-\sqsubset$

$8 r$

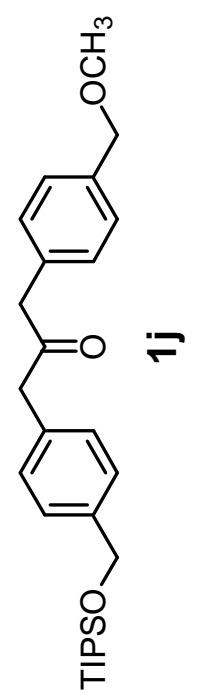

$9^{\circ} t$ 


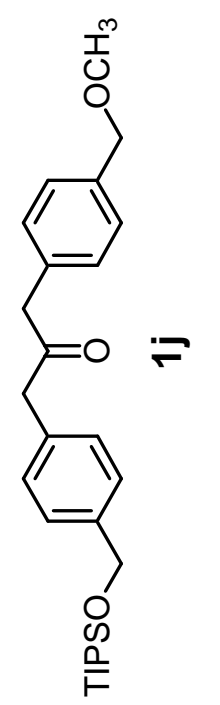


$9^{\circ} 9$

8.6

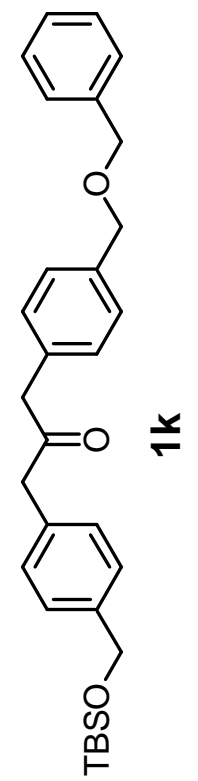

$\tau * t$

$0^{\circ} \dagger-\square$

$0^{\circ} t \quad-$

$9 \cdot 6$

SI-50 

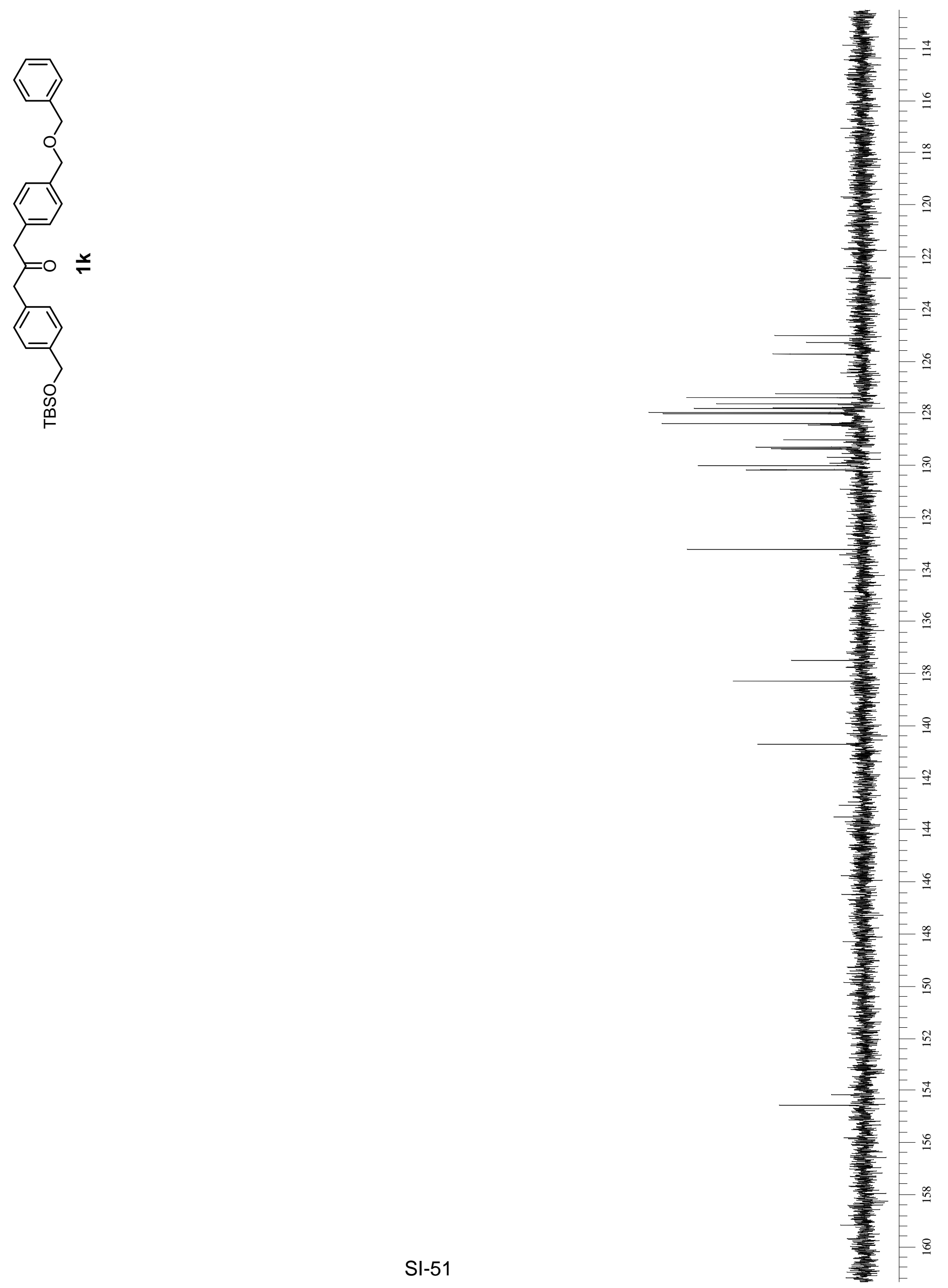

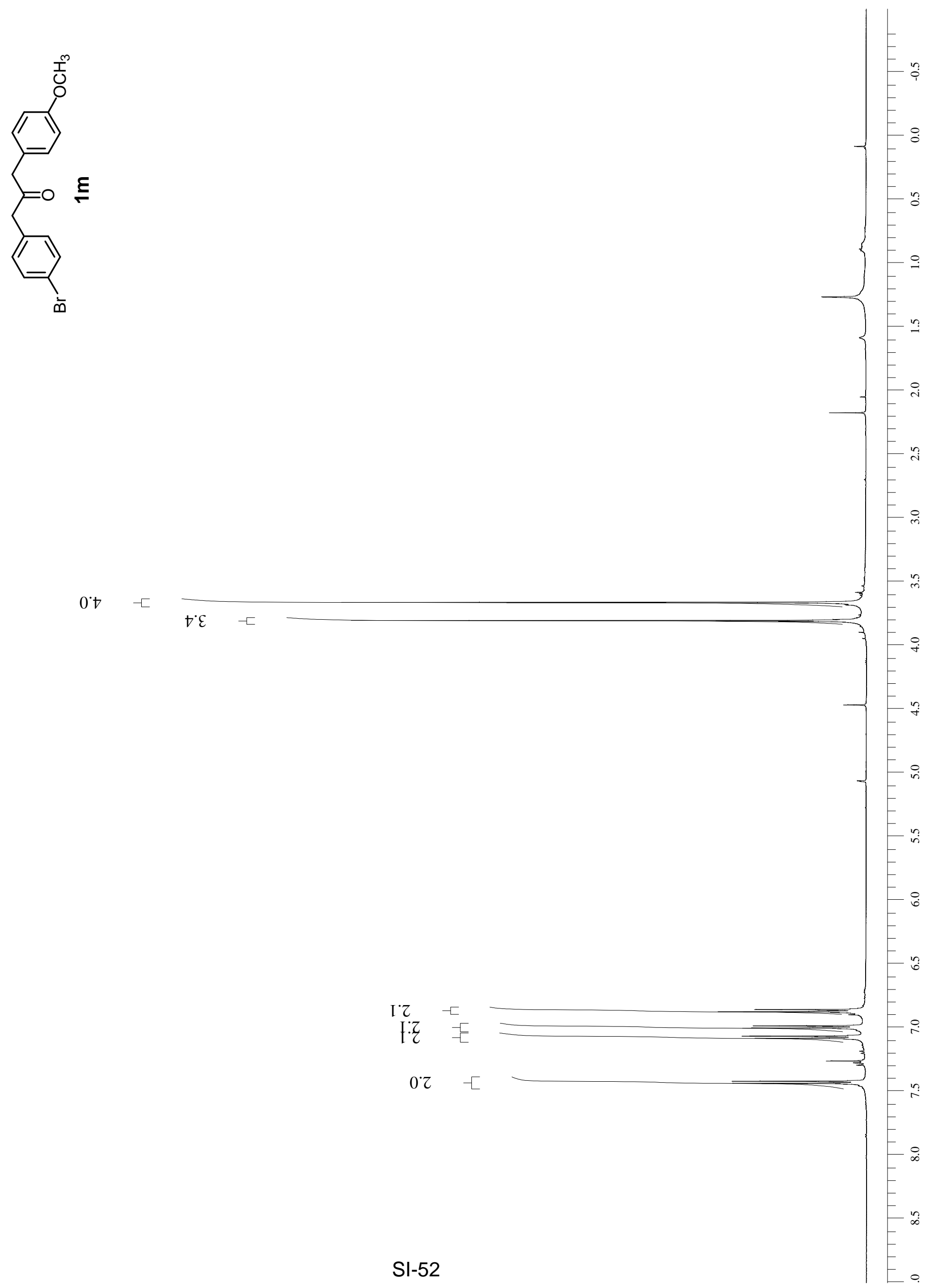

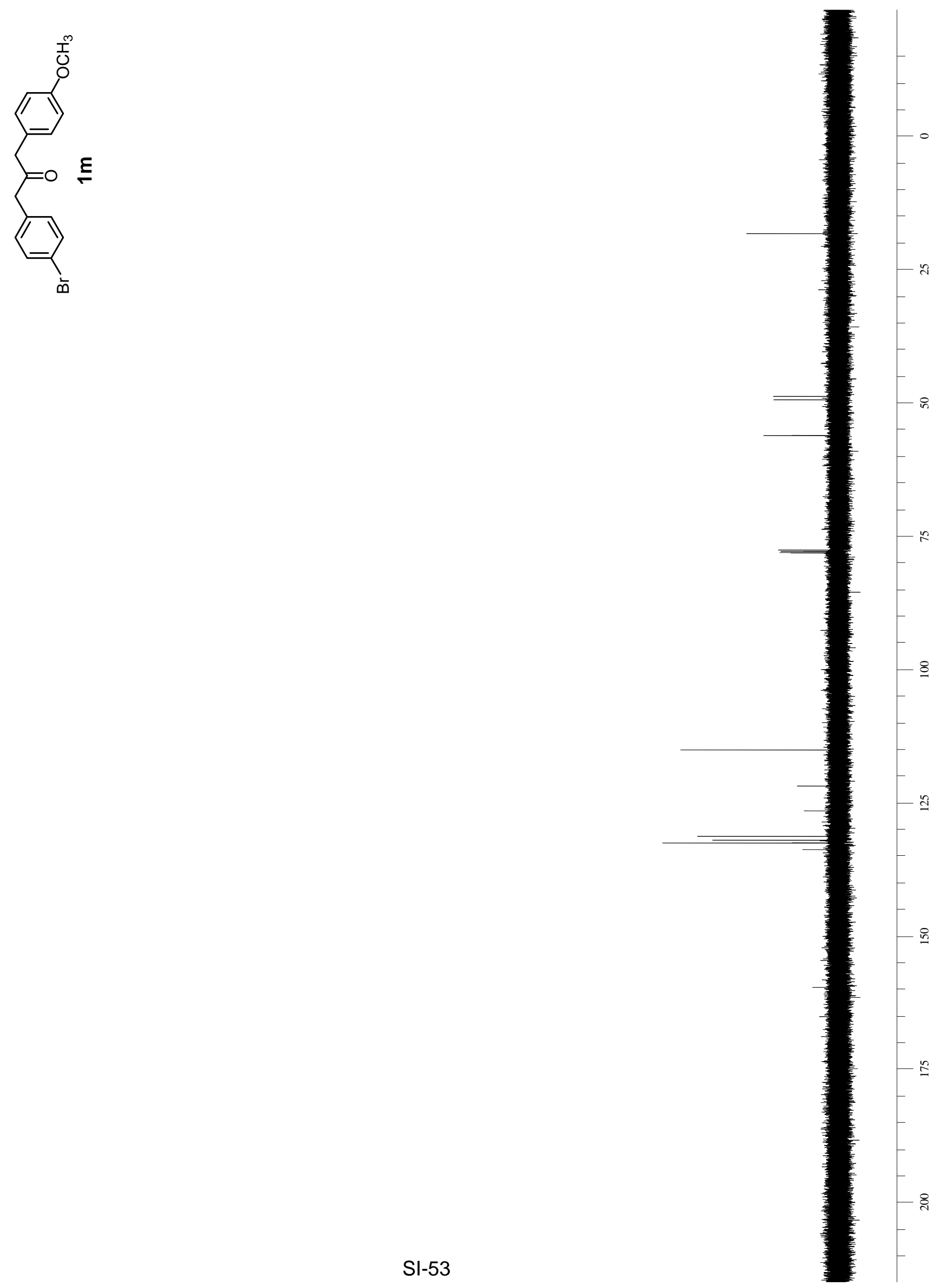

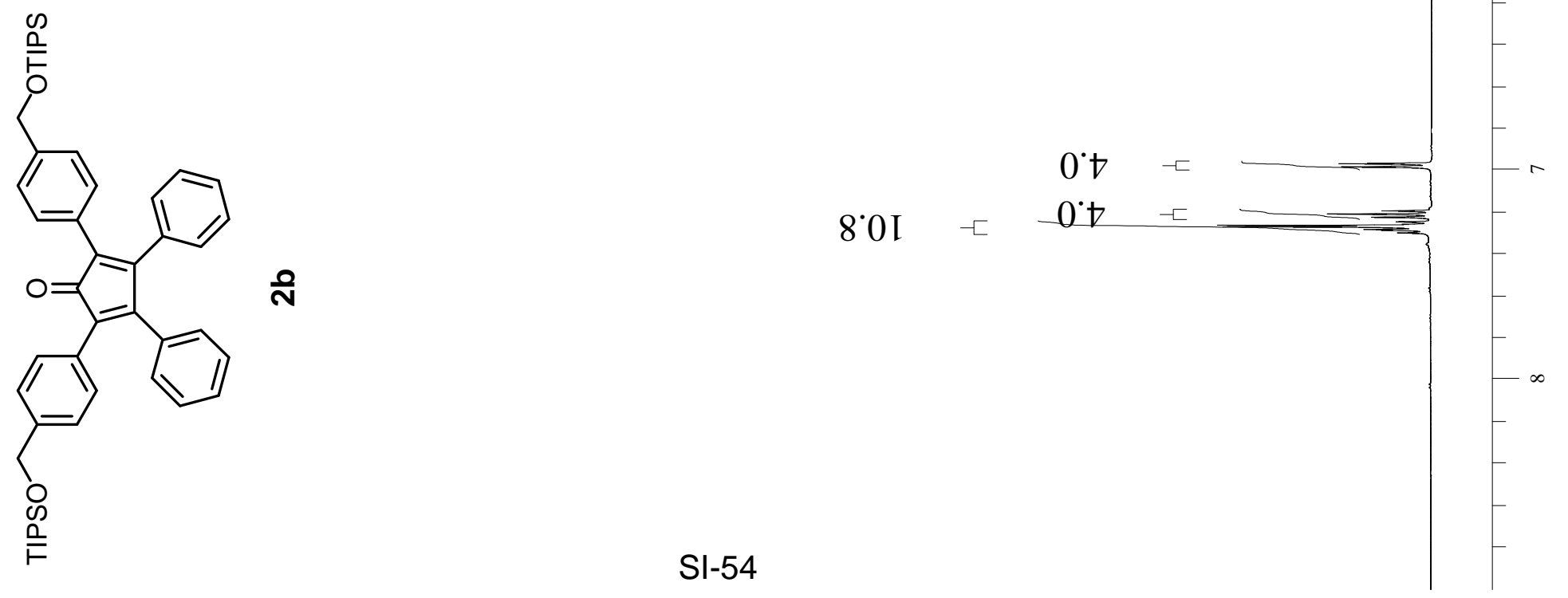


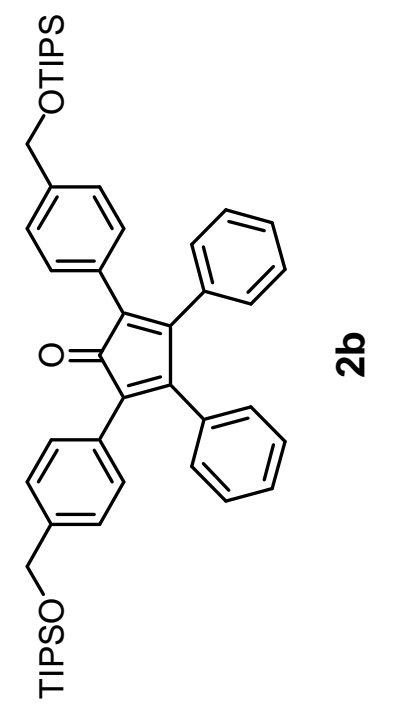




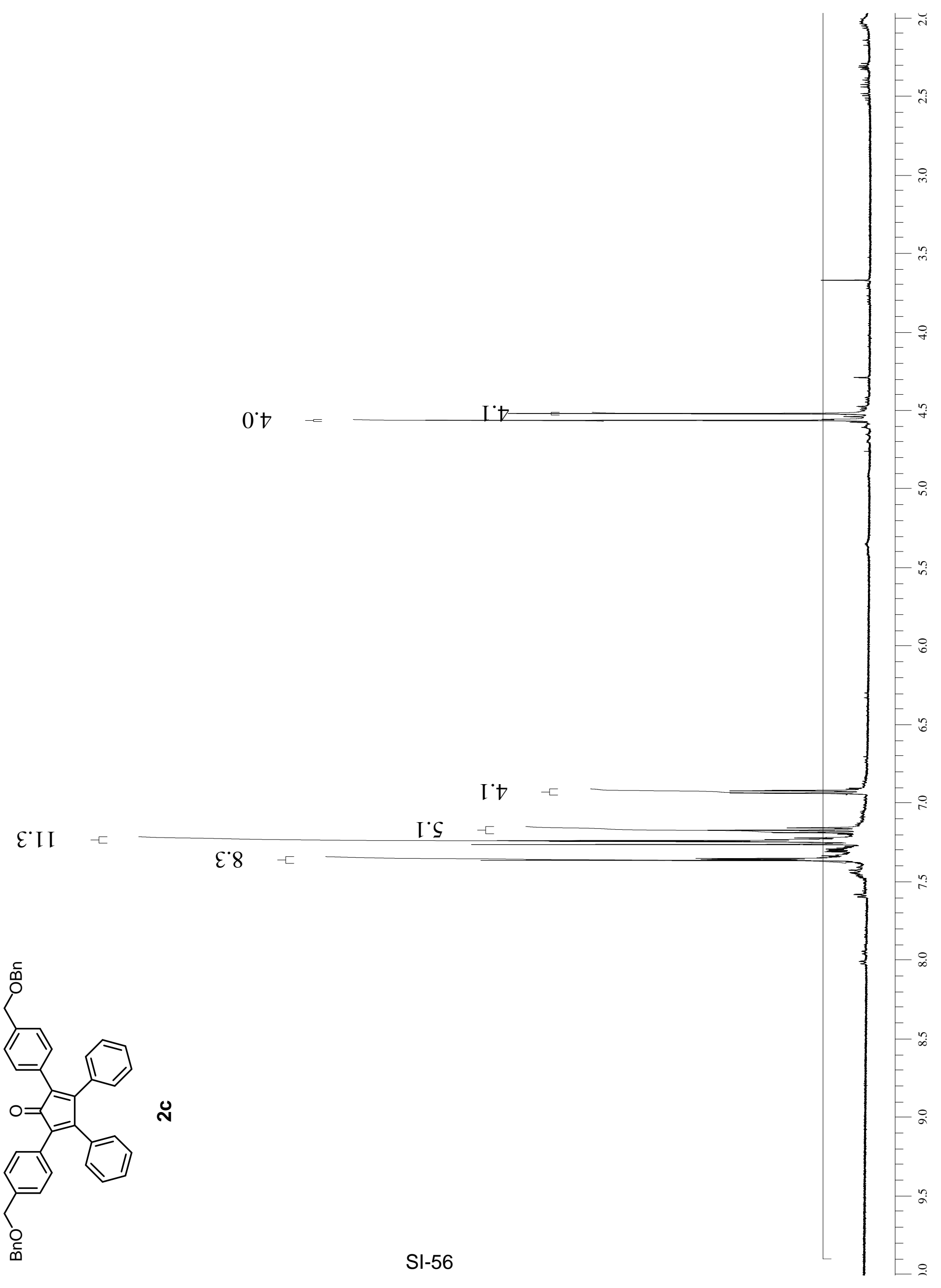




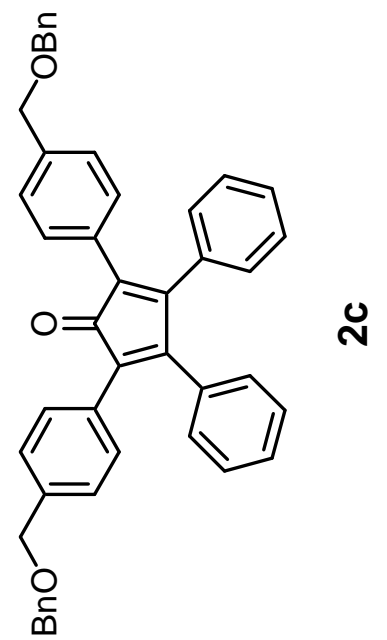




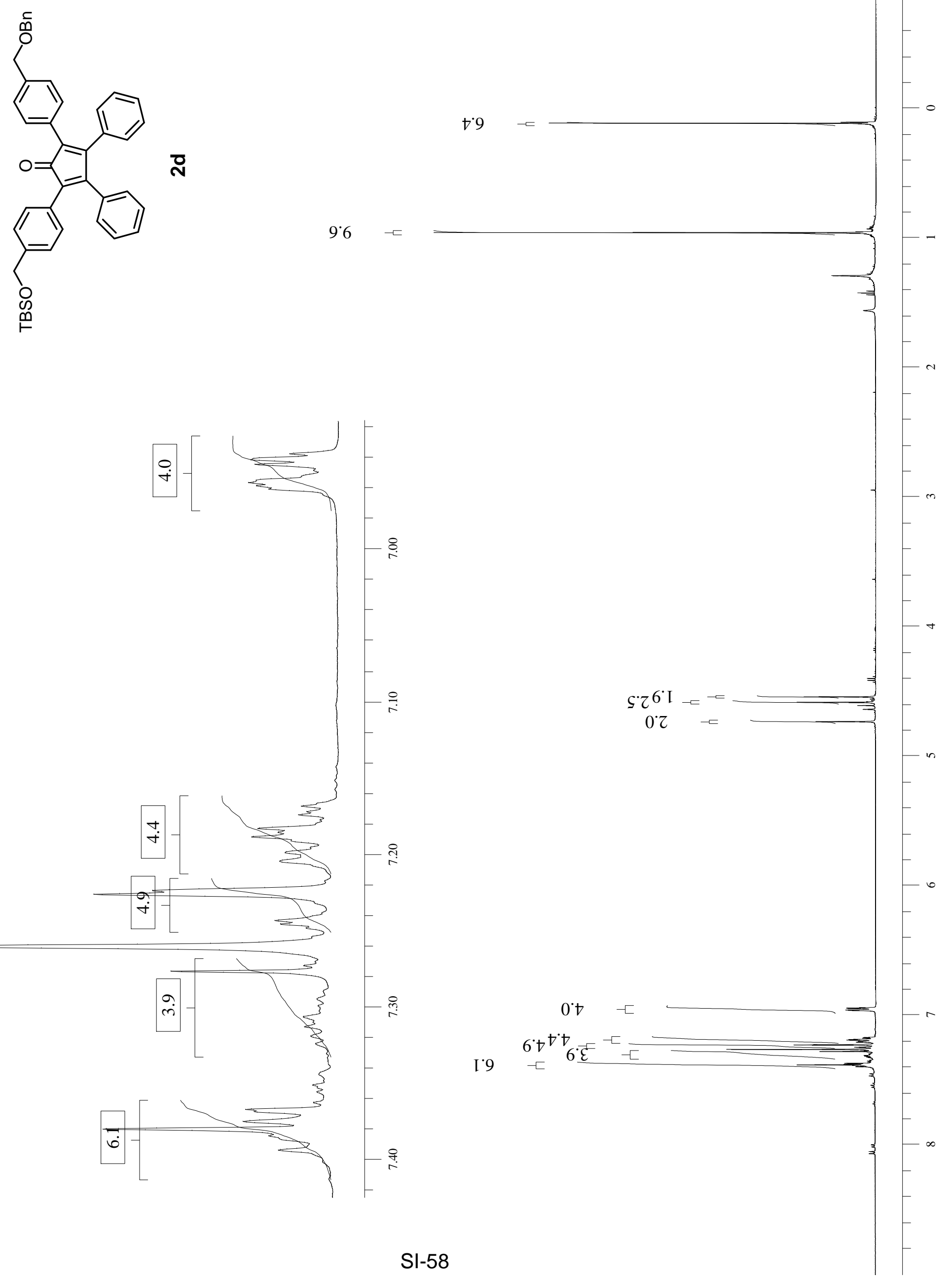




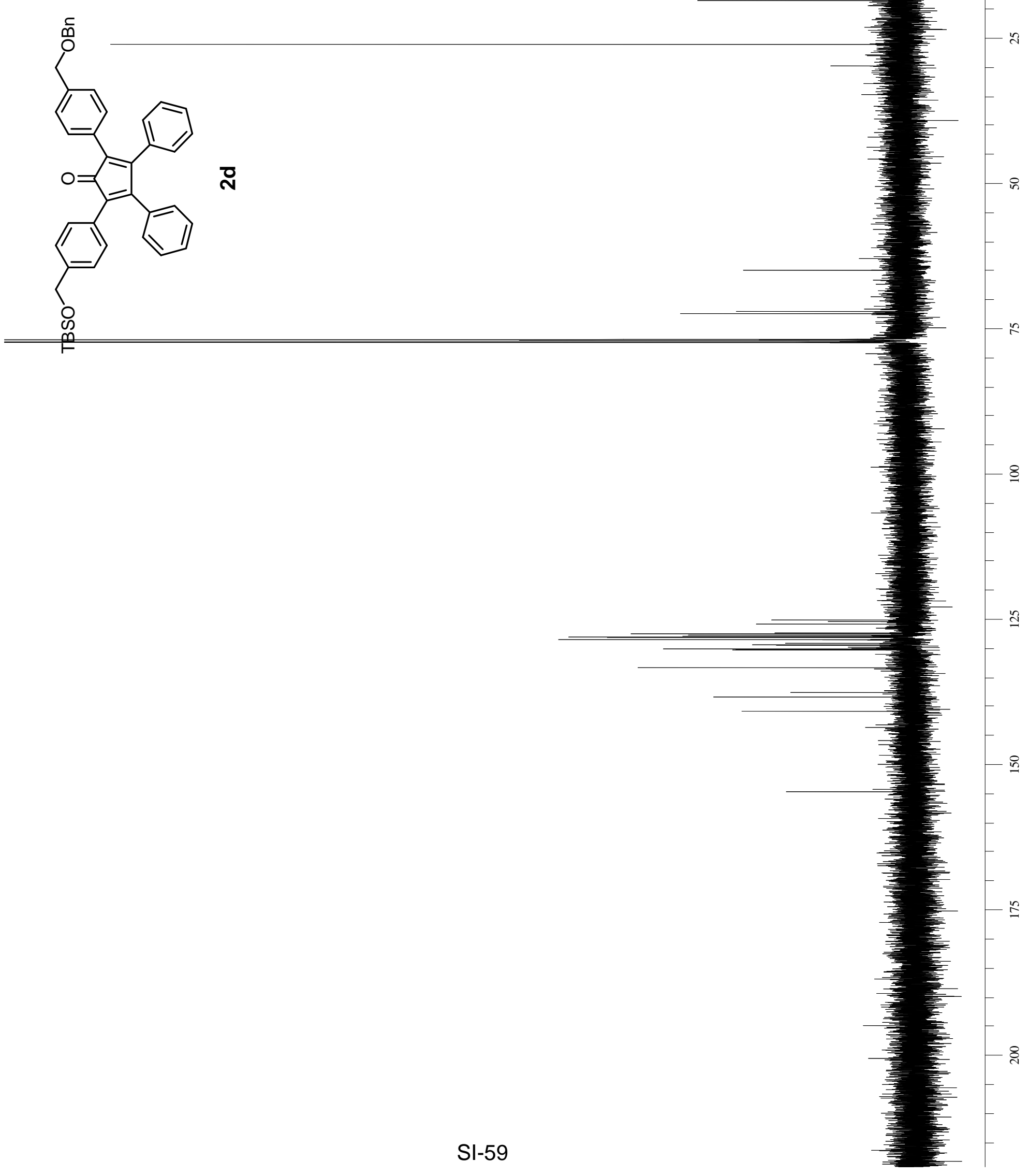




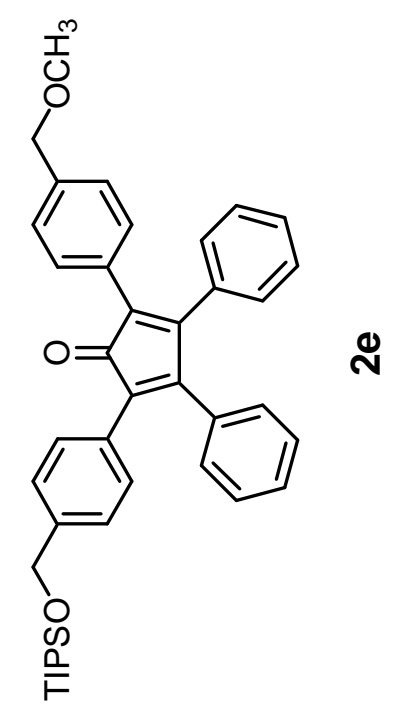

$I^{\circ} \mathcal{E}$

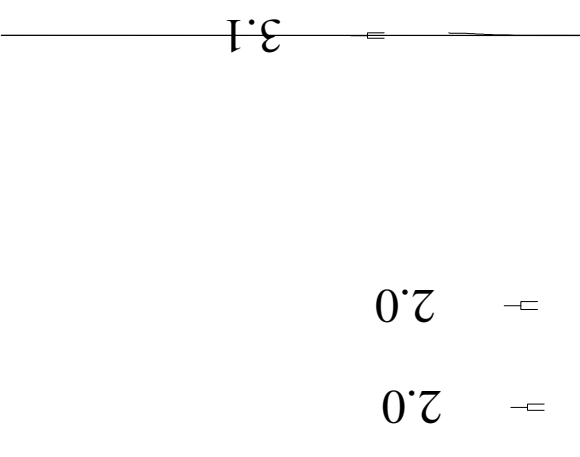

$8 \%$

It

$\nabla \nabla \quad-$ 

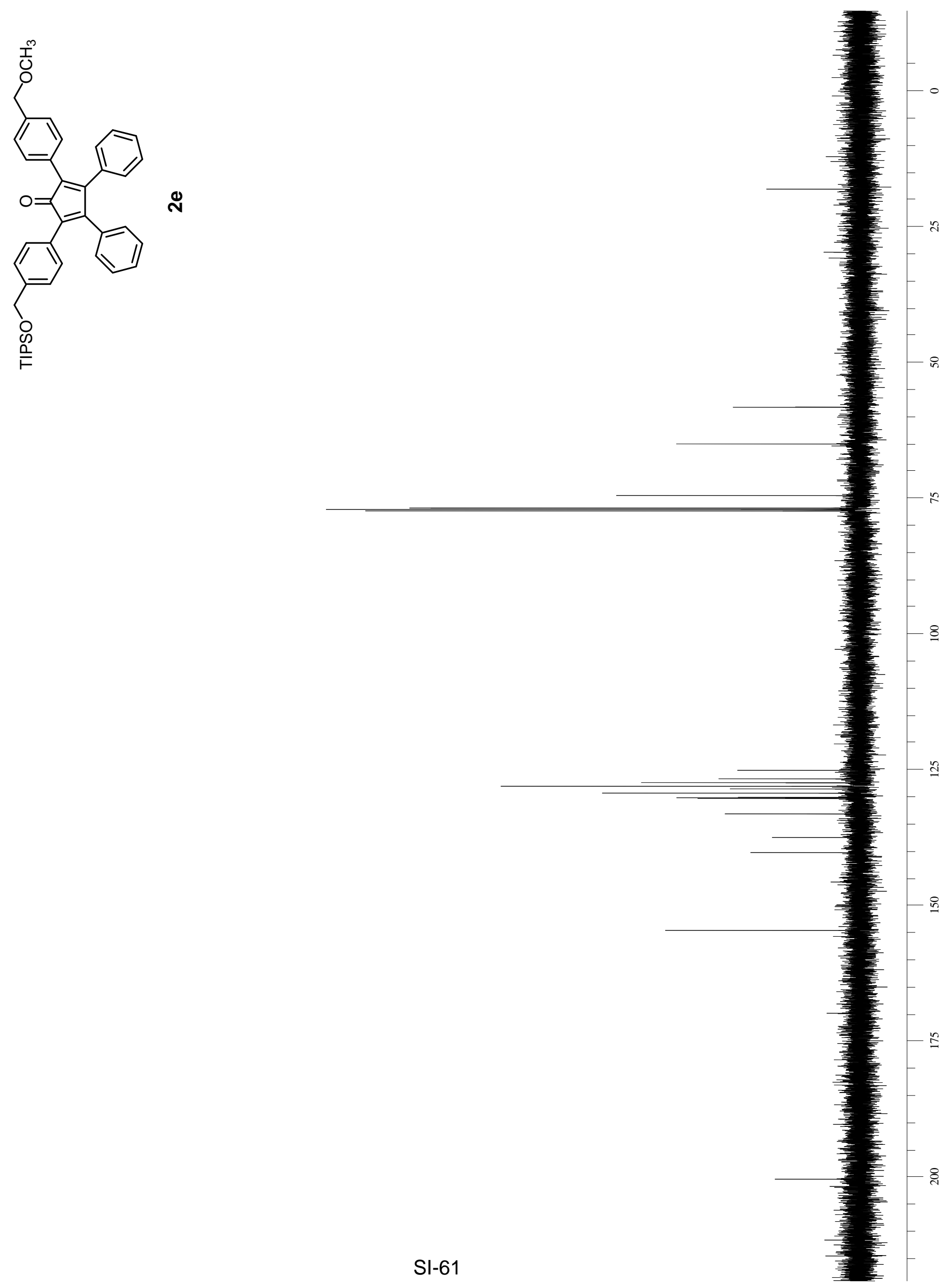


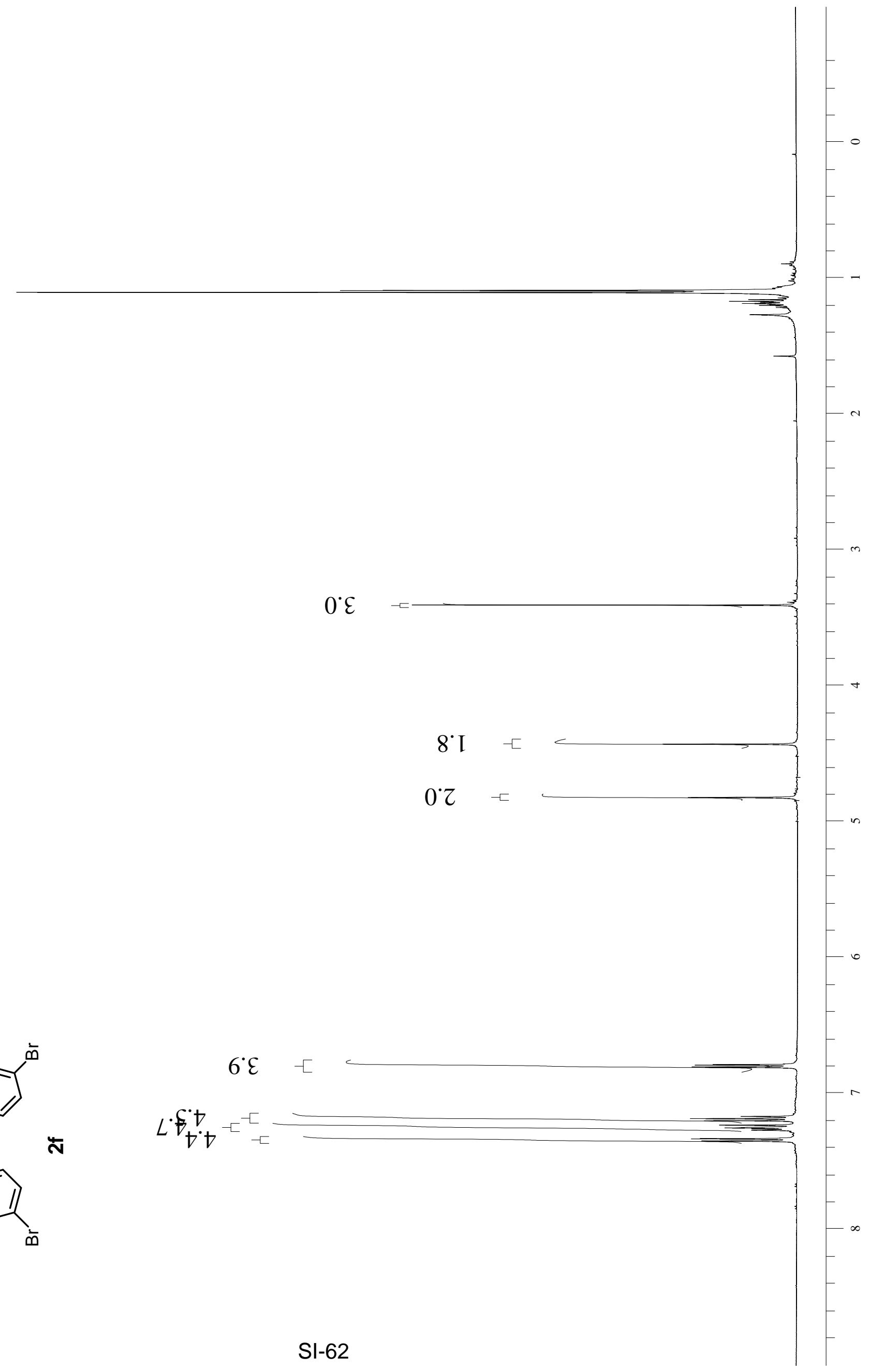



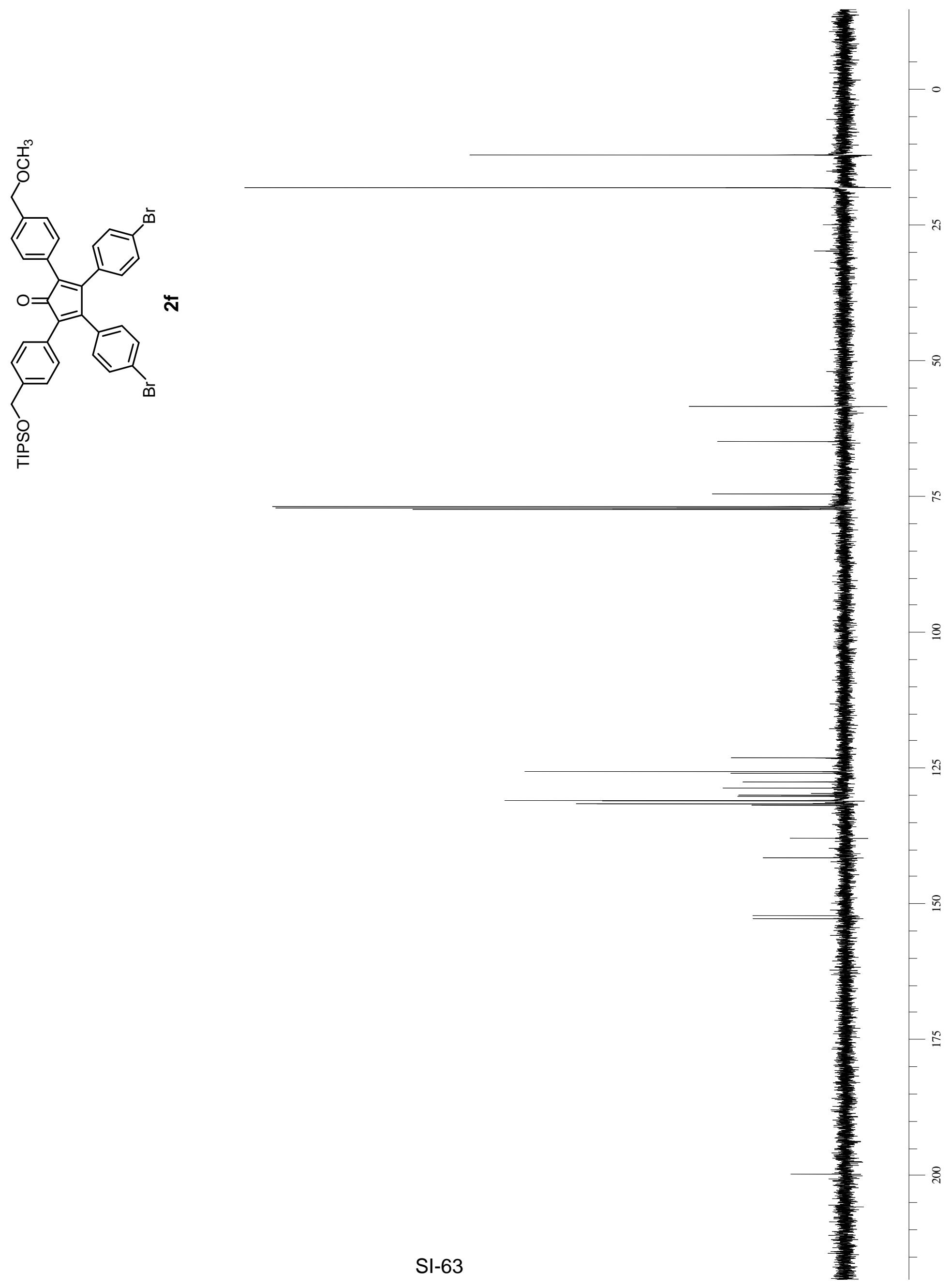


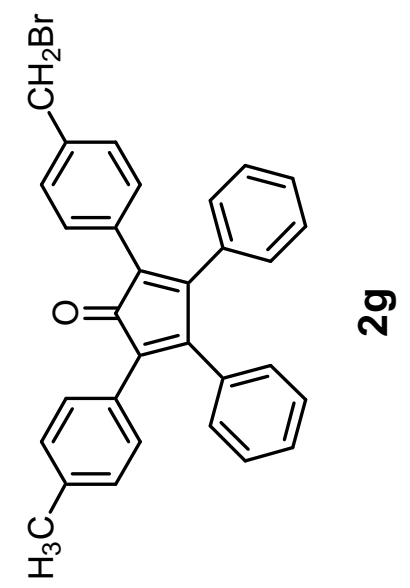

$\mathcal{E}^{*} 9-\sqsubset$

$\tau \cdot \mathcal{-} \quad-$

$0^{\circ} \mathrm{Z}$

$0^{\circ} \nabla-\sqsubset$ 证 


$\mid$




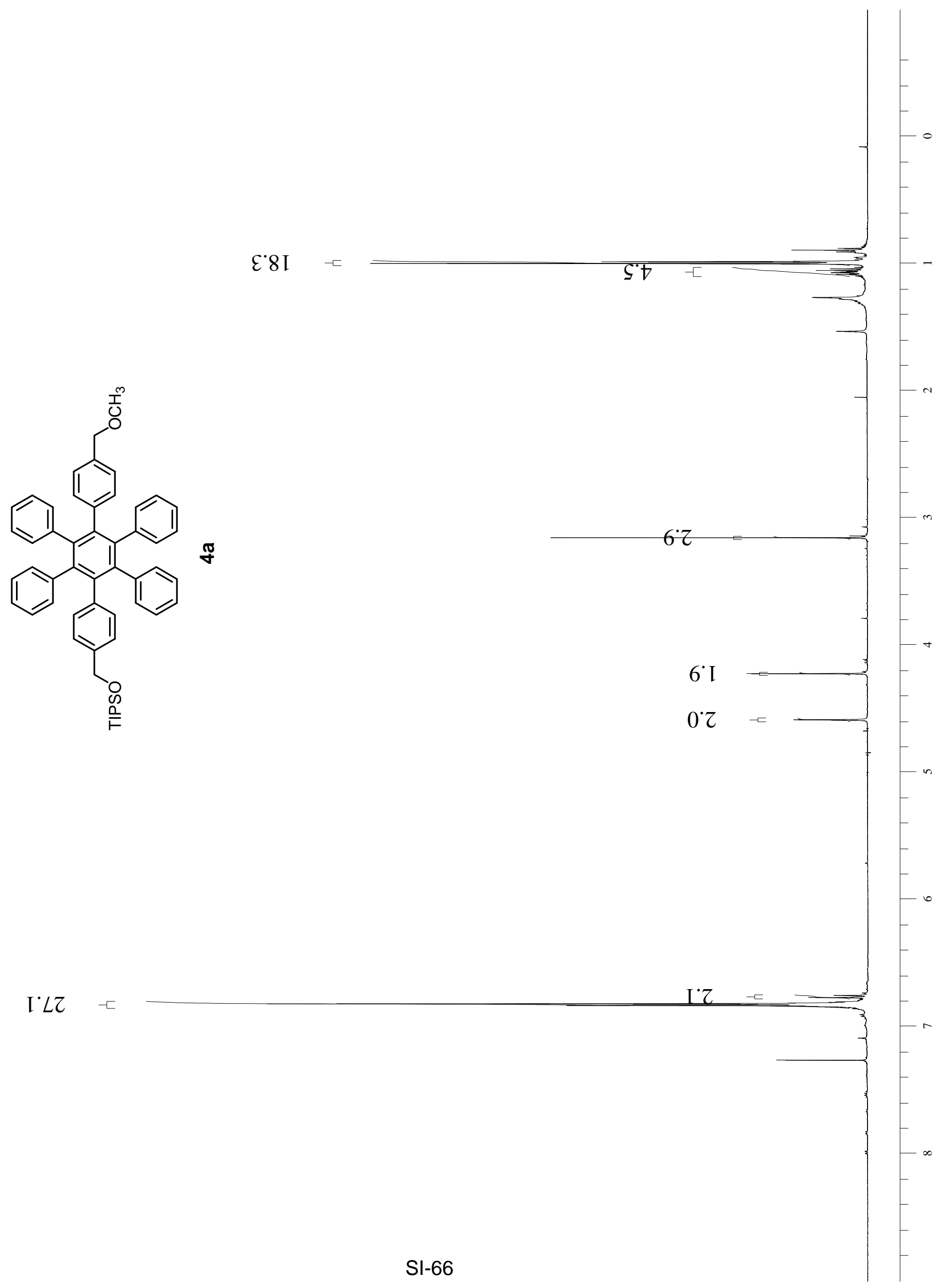


<smiles>[O]OCc1ccc(-c2c(-c3ccccc3)c(-c3ccccc3)c(-c3ccccc3)c(-c3ccc(COF)cc3)c2-c2ccccc2)cc1</smiles> 


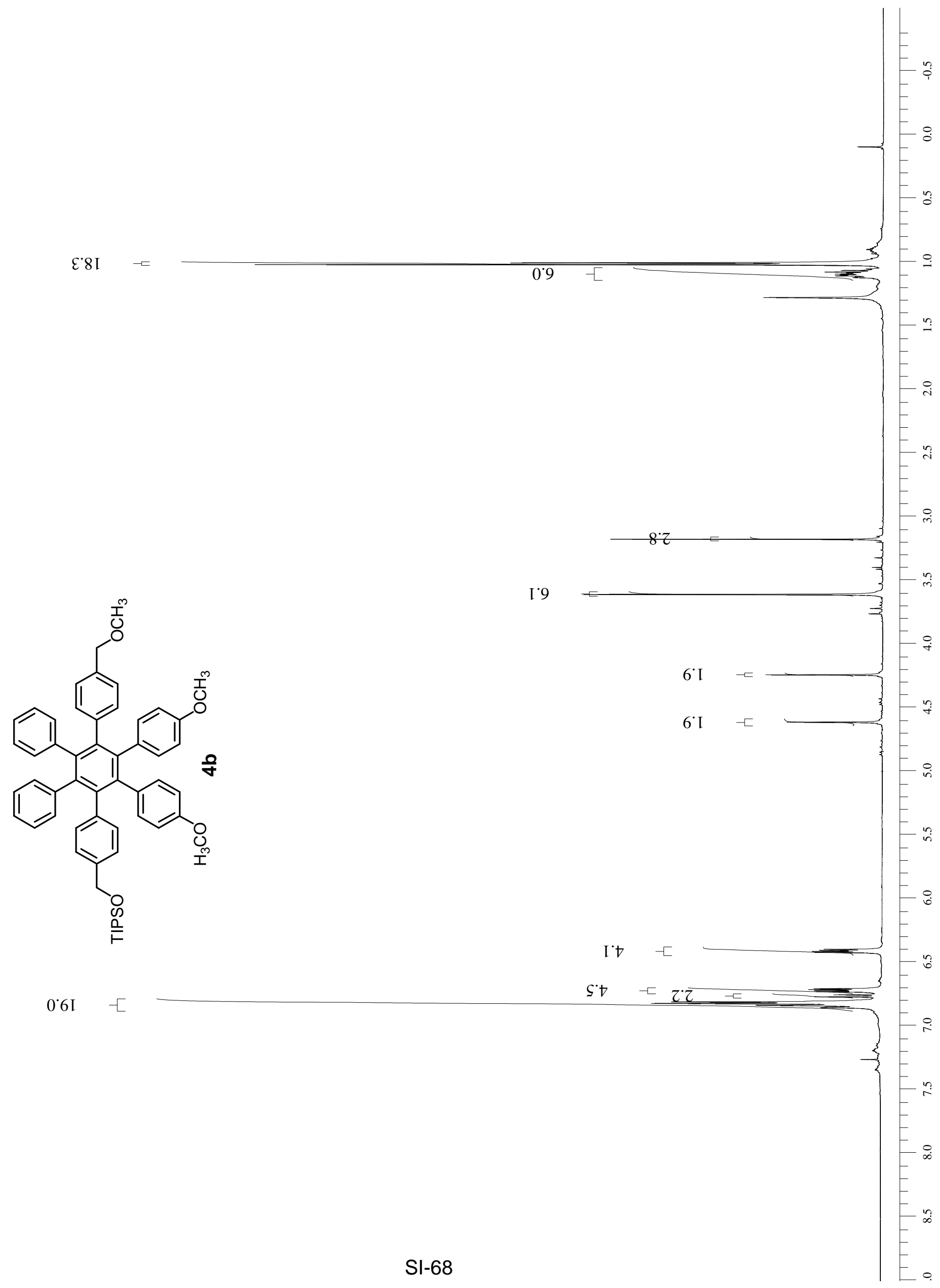




$$
1
$$


SLLI $\quad \sqsubset$
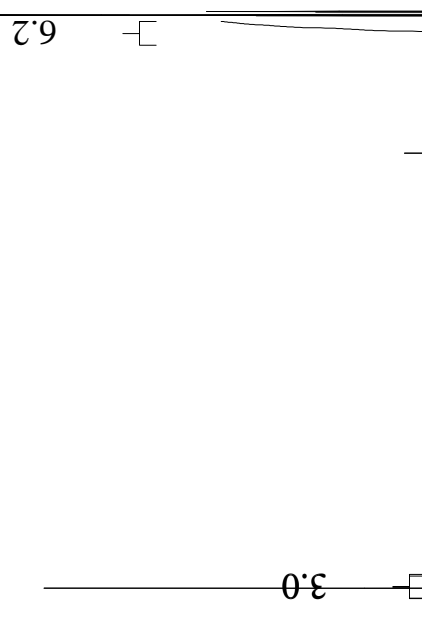

09
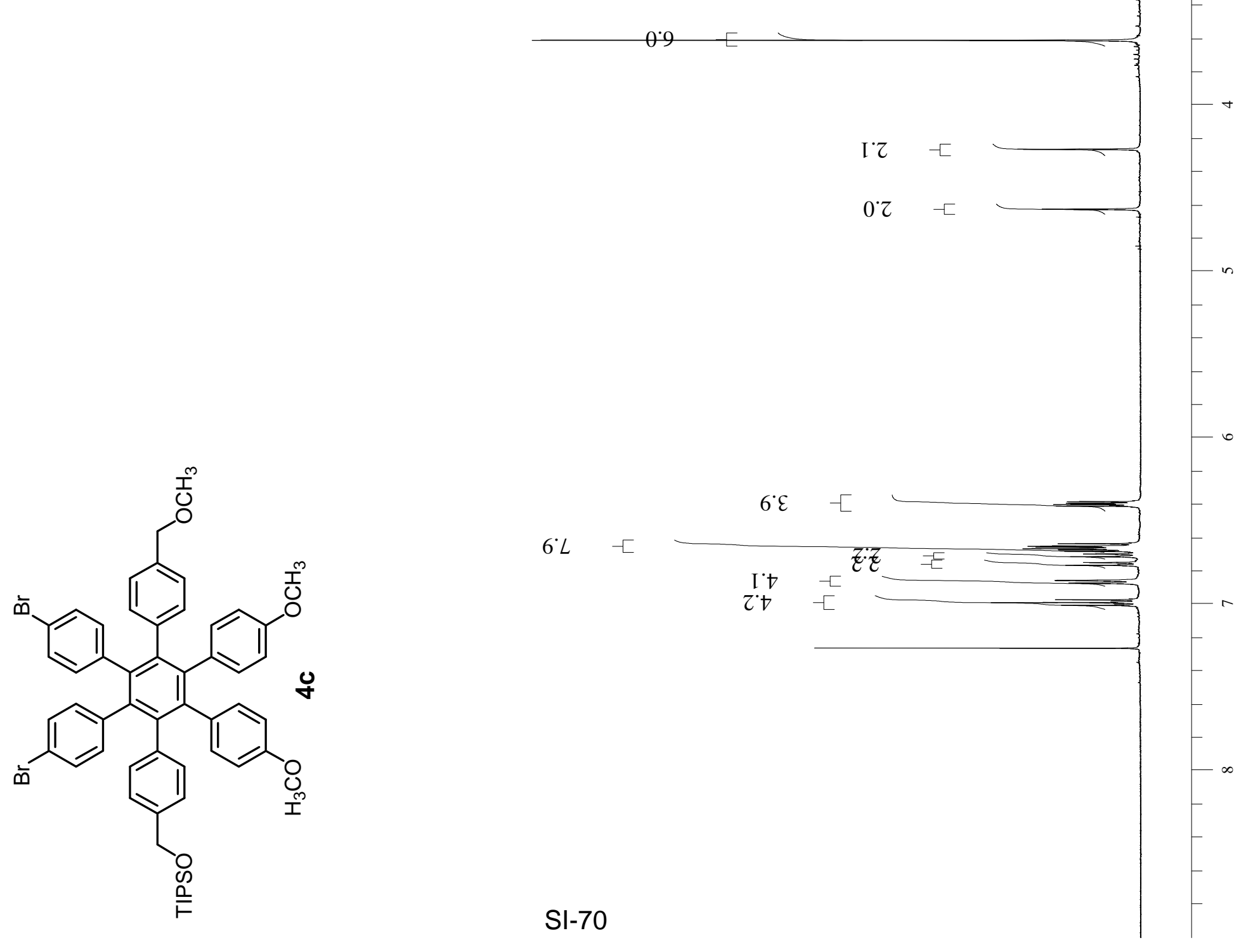


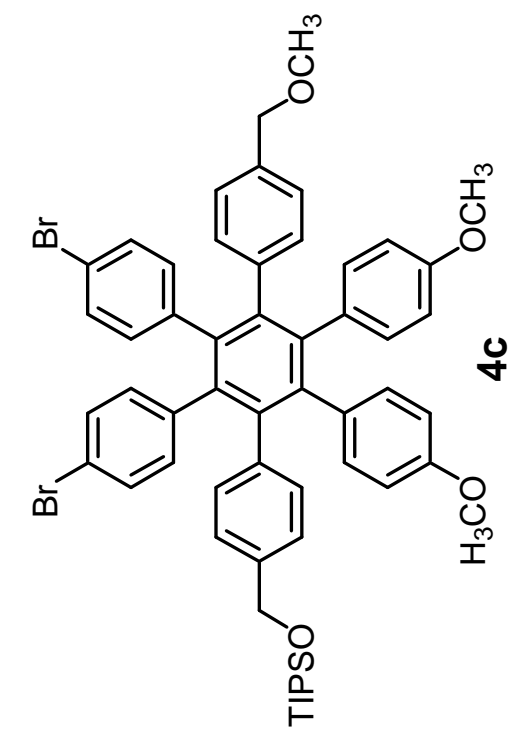




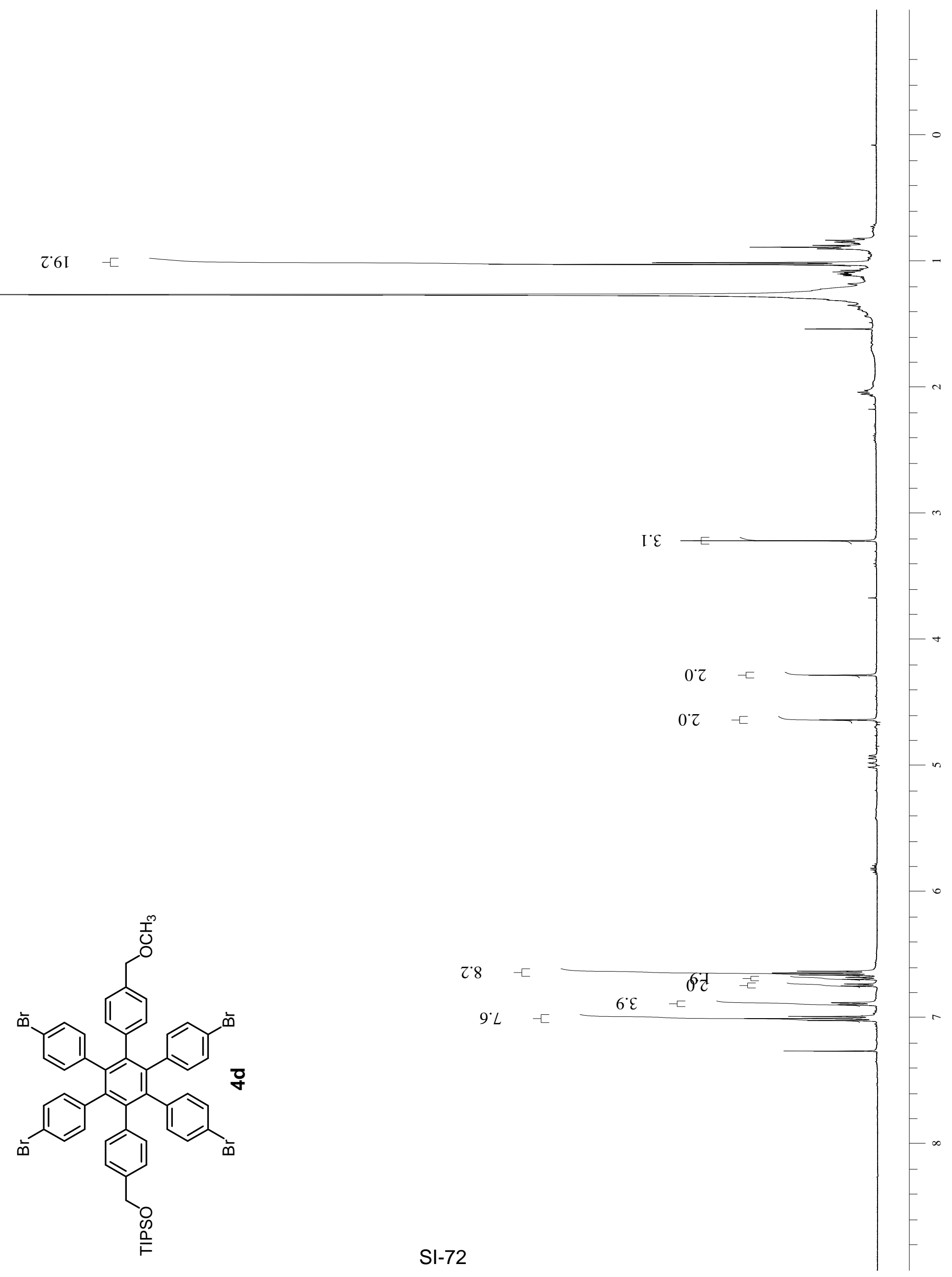




$$
1
$$

